Linköping University Medical Dissertation

No. 1513

\title{
Clinical aspects \\ of \\ childbirth-related anxiety
}

\author{
Katri Nieminen
}

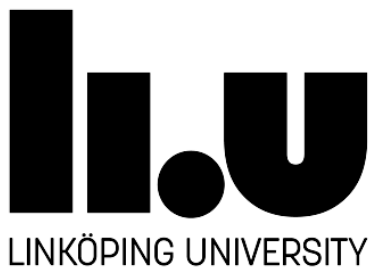

Medical Psychology

Department of Clinical and Experimental Medicine

Faculty of Medicine and Health Sciences

Linköping University, SE-581 83 Linköping, Sweden

Linköping 2016 
(C) Katri Nieminen 2016

katri.nieminen@liu.se

Cover illustration from 1965, made by an anonymous artist and published with permission of the owner of the illustration.

Reprints were made with permission of the publishers.

ISSN 0345-0082

ISBN: 978-91-7685-816-5

Printed in Sweden by LiU-Tryck, Linköping, Sweden 2016 
"Nothing in life is to be feared, it is only to be understood. Now is the time to understand more, so that we may fear less." Marie Curie 


\section{CONTENTS}

PREFACE - Personal starting point................................................. 1

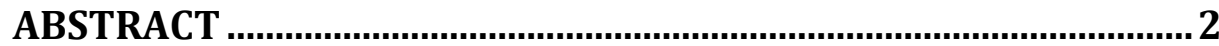

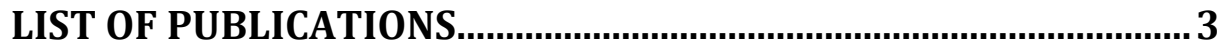

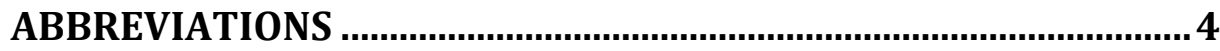

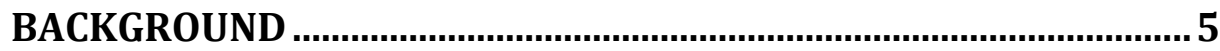

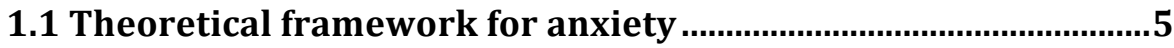

1.1.1 Emotions and cognitions .................................................................. 5

1.1.2 Psychological framework of phobic anxiety ...................................... 6

1.1.3 Psychological framework of PTSD ...................................................... 7

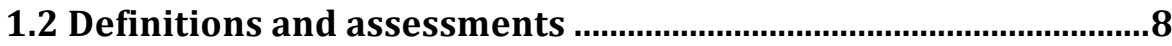

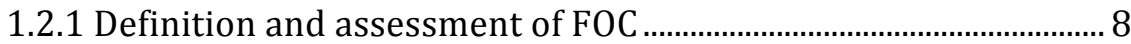

1.2.2 Definition and assessment of childbirth related PTSD.................. 9

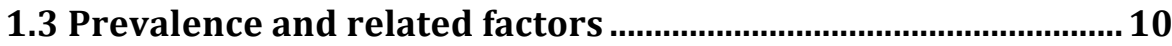

1.3.1 Prevalence of FOC................................................................................10

1.3.2 Prevalence of childbirth-related PTSD ..............................................11

1.3.3 Comorbidity of childbirth-related anxiety......................................11

1.3.4 Aetiology, vulnerability and risk factors for severe FOC .............12

1.3.5 Aetiology, vulnerability and risk factors for childbirth-related

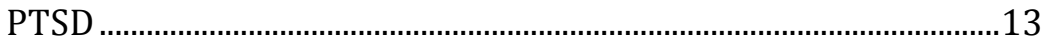

1.4 Consequences of severe FOC and childbirth-related PTSD ...... 14

1.4.1 Consequences of severe FOC …………….....................................15

1.4.2 Consequences of childbirth-related PTSD ………………………....15

1.4.3 Societal consequences of severe FOC................................................15

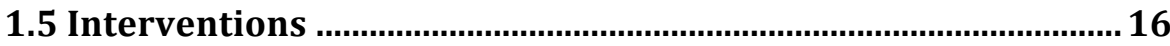

1.5.1 Treatment of anxiety problems …………………………………....16

1.5.2 Current knowledge of Internet interventions in the treatment of anxiety problems

1.5.3 Treatment of severe FOC and childbirth-related PTSD in obstetric care

1.5.4 Current knowledge of interventions with therapeutic elements in obstetric care.

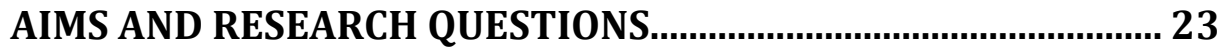

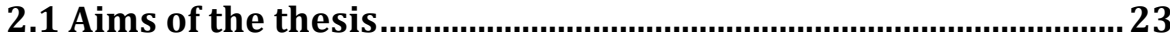

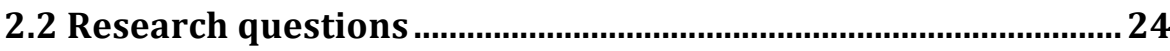

MATERIAL AND METHODS ............................................................ 25

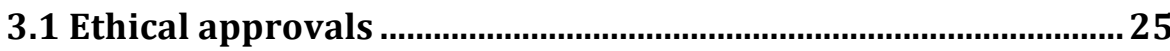




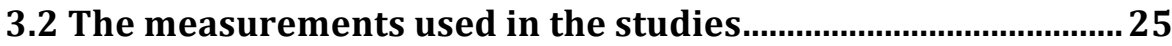

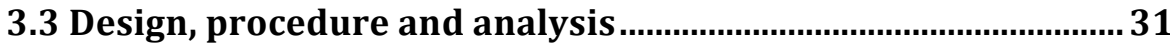

3.3.1 Prevalence of severe FOC and variables related to severe FOC and preference for CS (Study 1, Paper I) .........................................31

3.3.2 Cost of illness of severe FOC (Study 2, Paper II) .............................33

3.3.3 Treatment of severe FOC over the Internet (Studies 3 and 4, Papers III and IV).

3.3.4 Treatment of childbirth-related PTSD symptoms over the Internet (Study 5, Paper V)

RESULTS 50

4.1 Prevalence of severe FOC and variables related to severe FOC and preference for CS (Study 1, Paper I) 50

4.2 Cost of illness of severe FOC (Study 2, Paper II) ........................... 51

4.3 Treatment of nulliparous women with severe FOC over the Internet (Study 3 and 4, Paper III and IV) ..................................... 55

4.4 Treatment of childbirth-related PTSD symptoms over the

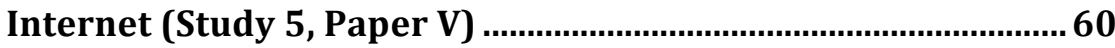

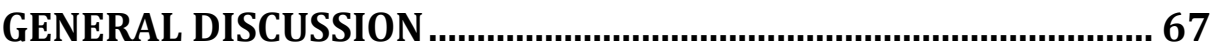

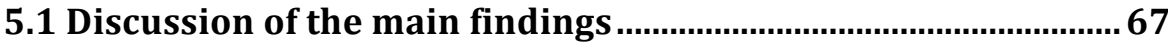

5.2 Methodological considerations - strengths and limitations .... 76

5.2.1 Study design: questionnaires ..........................................................76

5.2.2 Study samples and other methodological aspects .........................77

5.2 .3 Internet interventions ........................................................................78

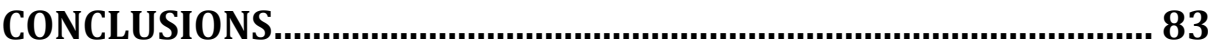

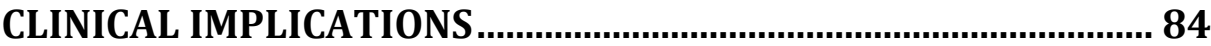

CONSIDERATIONS FOR FUTURE RESEARCH ................................ 85

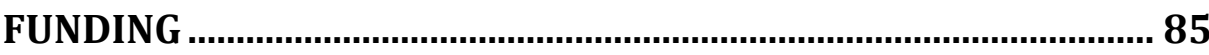

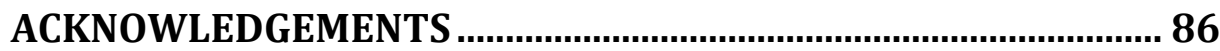

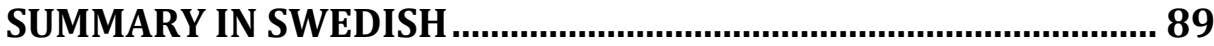

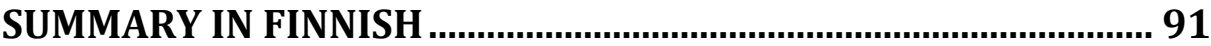

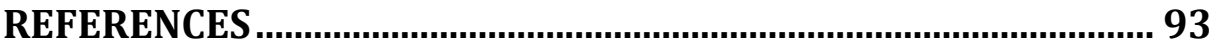

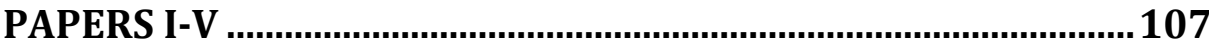


Preface 


\section{PREFACE - Personal starting point}

Since the beginning of the $21^{\text {st }}$ century there have been an increasing number of caesarean sections on maternal request in Western countries. In Sweden there is even an on-going discussion challenging the efficacy of the existing traditions within obstetrics concerning how to handle women who express their fear of giving birth. According to Swedish healthcare laws the pregnant women does not have the autonomy to request a CS, but can decline to have it performed. These urgent issues created the context of the questions that finally formed the basis of this thesis.

For most women, giving birth is one of the most significant events in life. My interest in the phenomenon of fear of childbirth (FOC) was trigged by the paradox of a physiologically autonomous event in the female body that in some women seemed to be obstructed by what happened in their minds. When meeting the women with severe FOC in the clinic, it struck me sometimes how strongly their fear could be felt in the delivery room and how it could even have an impact on the staff. I was also amazed at how some midwives, just through their physical presence could regain control of a chaotic situation and coach the birthgiving and frightened woman through the delivery, resulting in the woman achieving a new pride and a new self-confidence. These experiences awoke my interest in looking for common trends in successful ways of helping the women with severe FOC, which later on lead to a wish to develop even more helpful ways of meeting those women.

It is my hope that the knowledge collected in the studies reported in this thesis will open up new ways of approaching the problem of childbirthrelated anxiety and may help more women to gain access to psychological treatment.

Katri Nieminen

Linköping, April 2016 


\section{ABSTRACT}

Background: Although giving birth is a positive experience for many, some $10 \%$ of pregnant Swedish women suffer from severe fear of childbirth (FOC), which impairs their daily functioning and poses a risk for a negative delivery experience. This thesis focuses on the mental and health-economic effects of severe FOC, and explores new treatment options for childbirth-related anxiety.

Aims: (i) to investigate the prevalence of and variables associated with severe FOC, (ii) to estimate the cost of illness of severe FOC and (iii) to explore whether Internetbased cognitive behaviour therapy (ICBT) is feasible for treating pregnant women with severe FOC and those with childbirth-related symptoms of posttraumatic stress disorder (PTSD).

Design and Results: Study 1: In a cross-sectional study 1635 pregnant women were asked about their FOC via the Wijma Delivery Expectancy/Experience Questionnaire (W-DEQ), and provided socio-demographic data and information of their preferred mode of delivery. It was found that $15.6 \%$ of the participants had a severe FOC, which also strongly correlated with the preference of a caesarean section. Study 2: In a prospective case-control cohort study we mapped all visits, in-patient care, sick leave and delivery variables from medical records and estimated the societal costs in two groups of women; one group with severe FOC and one with low FOC. The costs for the group with severe FOC were 38\% higher than for the low FOC group. Study 3: Twenty-eight nulliparous women with severe FOC were self-recruited to an eight weeks ICBT program for severe FOC. Fifteen women followed the entire program. Their FOC decreased significantly after treatment (Cohen's $d=0.95, p<0.0001$ ), which means that ICBT is feasible and an option for treating women with severe FOC. Study 4: Fifteen participants in Study 3 wrote narratives of the imminent delivery before as well as after therapy. After treatment, the women had a more realistic attitude towards childbirth, more self-confidence and more active coping strategies. Partners and staff were perceived as more helpful, and the women were more aware of the child they were bearing. Study 5: Fifty-six women with a traumatic delivery experience were included in a randomized wait-list controlled study (RCT) of the effects of an eight week long ICBT program for childbirth-related PTSD symptoms. These symptoms decreased in both groups during active therapy, while the between-group effect size varied depending on measurements. Psychiatric comorbidity decreased in both groups after active treatment.

Conclusion: Severe FOC is prevalent among Swedish pregnant women, and the cost of illness of this marker of peripartum psychological vulnerability is considerable when treated using standard care. A new treatment option for this group with ICBT seems feasible and is associated with more realistic attitudes towards the imminent delivery. An RCT with eight weeks of ICBT for parous women with PTSD symptoms also had promising results.

As severe FOC is prevalent and associated with mental and economic burdens for the individual and the society, there is an urgent need to expand the research field. It is important to find feasible and effective treatments that can be applied on a large scale. 


\section{LIST OF PUBLICATIONS}

This thesis is based on Studies 1-5, which are published in the following original Papers I-V, referred to in the text by the roman numerals:

Paper I Nieminen, K., Stephansson, O., Ryding, E.L. (2009). Women's fear of childbirth and preference for cesarean section - a cross-sectional study at various stages of pregnancy in Sweden. Acta Obstetricia et Gynecologica Scandinavica, 88(7), pp. 807-813.

Paper II Nieminen, K., Wijma, K., Johansson, S., Kneckt Kinberger, E., Ryding, E.L., Andersson, G., Bernfort, L., Wijma, B. What is the price of severe fear of childbirth in Swedish women giving birth to their first child? Submitted manuscript.

Paper III Nieminen, K., Andersson, G., Wijma, B., Ryding, E.L., Wijma, K. (2016). Treatment of nulliparous women with severe fear of childbirth via the Internet: a feasibility study. Journal of Psychosomatic Obstetrics \& Gynecology, February (26), pp. 1-7.

DOI: 10.3109/0167482X.2016.1140143.

Paper IV Nieminen, K., Malmquist, A., Wijma, B., Ryding, E.L., Andersson, G., Wijma, K. (2015). Nulliparous pregnant women's narratives of imminent childbirth before and after Internet-based cognitive behavioural therapy for severe fear of childbirth: a qualitative study. BJOG, An International Journal of Obstetrics and Gynaecology 122(9), pp. 1259-1265.

Paper V Nieminen, K., Berg, I., Frankenstein, K., Viita, L., Larsson, K., Persson, U., Spånberger, L., Wretman, A., Silfvernagel, K., Andersson, G., Wijma, K. (2016). Internet-provided cognitive behaviour therapy of posttraumatic stress symptoms following childbirth - a randomized controlled trial. Accepted: Cognitive Behaviour Therapy. DOI: 10.1080/16506073.2016.1169626. 


\section{ABBREVIATIONS}

$\begin{array}{ll}\text { CA } & \text { Childbirth anxiety } \\ \text { FOC } & \text { Fear of childbirth } \\ \text { PTSD } & \text { Posttraumatic stress disorder } \\ \text { CS } & \text { Caesarean section } \\ \text { W-DEQ A } & \begin{array}{l}\text { Wijma Delivery Expectancy/Experience Question- } \\ \text { naire version A; measures fear of childbirth before } \\ \text { childbirth }\end{array} \\ \text { W-DEQ B } & \text { Wijma Delivery Expectancy/Experience }\end{array}$

Questionnaire version B; measures fear of childbirth after childbirth

Severe FOC W-DEQ sum score $\geq 85$; called intense FOC in Paper I

Phobic FOC W-DEQ sum score $\geq 100$; called tocophobic or very intense FOC in Paper I

Low FOC W-DEQ sum score $\leq 60$

Moderate FOC W-DEQ sum score 61-84

TES

Traumatic Event Scale

HADS

IES-R

Hospital Anxiety and Depression Scale

PHQ9

Impact of Event Scale Revised

BDI-II

Patient Health Questionnaire 9 items

BAI

QOLY

EQ5D

DSM-IV

DRG

MINI

CBT

ICBT

Exposure

in vivo

Exposure in vitro

Beck Depression Inventory-II

Beck Anxiety Inventory

Quality of Life Inventory

Euroqol 5 Dimensions

Diagnostic and Statistical Manual of Mental Disorders $4^{\text {th }}$ Edition

Diagnosis Related Groups

MINI International Neuropsychiatric Interview

Cognitive behaviour therapy

Internet-based cognitive behaviour therapy

Direct exposure - exposure in reality

Indirect exposure - imaginary exposure 


\section{BACKGROUND}

The title of this thesis includes the term "childbirth-related anxiety" to cover both (pre- and postpartum) fear of childbirth (FOC) and (postpartum) childbirth-related posttraumatic stress disorder (PTSD). When the ordinary obstetric care is discussed, the term refers to Swedish circumstances if no other context is mentioned.

The participants in the studies in the thesis are called parous women, when they have previously given birth (Studies 1 and 5). When the participants are pregnant with their first child they are called nulliparous women (Studies 1-4).

\subsection{Theoretical framework for anxiety}

\subsubsection{Emotions and cognitions}

Emotions can evolutionary be seen as a basic state of preparedness, assisting to act, with the purpose to motivate behaviours related to survival of the species (Barlow 2004 p. 54). Some of these behaviours include preparing for, avoiding or escaping from potentially life-threatening or dangerous events (e.g. emotions of fear or anxiety), or seeking protection and support from fellow members of the species (e.g emotions of pride, relief, envy, shame and guilt), gaining access to sexual partners (e.g. emotions of compassion, hope), engaging in sexual relations (e.g. emotions of love and happiness) and caring for offspring (e.g. emotions of compassion and love) (Nolen-Hoeksema, Frederickson, Loftus \& Wagenaar 2014 pp. 378-388).

Emotion activation is a complex neuro-bio-psycho-social process (Barlow 2004 pp. 62-63). In the creation of an emotion, components of subjective experience of the emotion, internal physical responses, thoughts and beliefs accompanying the emotion, facial expressions, reactions to the emotion, and action tendencies influence each other (NolenHoeksema et al. 2014 p. 349). The cognitive appraisal of the situation and the interpretation of the appraisal determine whether a person will experience fear in a given situation (Lazarus 1991). 
A usual response to the appraising of danger is anxiety, which is often divided into trait and state anxiety. Trait anxiety refers to a personal characteristic, and is mainly a tendency to respond with anxiety, while state anxiety is an emotional response in a specific situation, more like a transient reaction that depends on particular conditions (Lazarus 1991). Trait anxiety can be influenced by the individual's experiences in the past (Spielberger, Jacobs, Russell \& Crane 1983). Persons with high trait anxiety are more prone to react with anxiety, i.e. persons with higher trait anxiety exhibit state anxiety more frequently than those with lower trait anxiety, which makes trait anxiety self-stimulating (Lazarus 1991).

Individuals who have no or low anxiety reactions in situations that provoke fear in others, can turn their attention away from the given situation; probably because they neither interpret the situation, nor their own reactions of anxiety as problematic (Torgersen 1985).

According to Bandura (Bandura 1977), self-efficacy beliefs, i.e. how the individual perceives her capabilities in a future situation, will not only affect motivation to act, but will also influence the chosen behaviour in a given situation. Consequently, treatments designated to increase an individual's self-efficacy should focus on at least one of the four sources that influence self-efficacy, i.e. (i) a sense of mastering (being the most effective source); (ii) vicarious experiences, seeing successful role models; (iii) social persuasion; (iv) reduction of somatic and emotional stress responses (Bandura 1977).

\subsubsection{Psychological framework of phobic anxiety}

According to Barlow (2004 pp. 404-408) a specific phobia is developed when either a true or a false alarm is associated with a previously neutral event or object that emerges in immediate proximity and then is generalized to other previously neutral situations. The emotional learning by conditioning is fundamental to the development of anxiety reactions. (In this thesis, anxiety and fear are considered as synonyms).

Barlow assumes three pathways for fear; direct experience (by selfexperiencing), vicarious experience/observational learning (watching another person experiencing) and information/instruction (reading or 
hearing of the dangers) (Barlow 2004 pp. 404-408). According to Barlow's model of the aetiology of specific phobias, the development of a specific phobia is a combination of bio- and psychological vulnerability, interacting with specific life events. A true alarm can be awakened by a direct traumatic experience, giving rise to a learned alarm (learned anxiety) due to the dangerous event itself, and finally, by generalization, this can lead to a specific phobia (Barlow 2004 p. 408).

Negative life events may cause stress, resulting in a false alarm that, when associated with a specific situation, can develop to a specific phobia if the person has been sensitized to a specific phobic situation through early experiences (i.e. a specific psychological vulnerability). Even vicarious experience and misinformation in combination with bioand psychological vulnerability can lead to true or false alarms that can be associated with objects or events that become triggers of a phobia (Barlow 2004 pp. 404-408).

\subsubsection{Psychological framework of PTSD}

In his model of the aetiology of PTSD, Barlow (2004 p. 429) suggests that generalized bio- and psychological vulnerability influence the experience of a potentially traumatic stimulus, where a true alarm ("intense basic, automatically activated unconditioned emotions") leads to a learned alarm ("strong mixed conditioned emotions connected to originally neutral stimuli"). Learned emotions in turn occur during exposure to situations that symbolize or resemble the traumatic event (triggers). This leads to fear, avoidance, or numbing of emotions. Social support and the persons' coping strategies moderate the chain of the development of PTSD.

The emotional intensity of the experienced event (the trauma), together with the bio- and psychological vulnerability and the moderating variables in the context, determine whether the situation results in a specific phobia or in PTSD (Barlow 2004 pp. 428-431). 


\subsection{Definitions and assessments}

\subsubsection{Definition and assessment of FOC}

It is observed in several samples of women (Zar, Wijma \& Wijma 2001; Rouhe, Salmela-Aro, Halmesmäki \& Saisto 2009), that the intensity of FOC appears as a continuum, varying from almost no fear to a paralyzing specific phobia. FOC is regarded as clinically significant, i.e. needing extra attention from the health care system, when it interferes with the woman's daily routines, professional life, social activities or relationships, either before, during or after giving birth (Wijma \& Wijma 2016). As FOC is related to a specific situation, a vicious circle phenomenon has been observed (Zar, Wijma \& Wijma 2001; Alehagen, Wijma \& Wijma 2006; Sluijs, Cleiren, Scherjon \& Wijma 2012), where women's FOC, before, during and after delivery are closely related; i.e. women with severe FOC before delivery are also prone to have severe FOC during the delivery as well as postpartum.

FOC can become so severe that it meets the criteria of a specific phobia according to the Diagnostic and Statistical Manual of Mental Disorders $4^{\text {th }}$ edition (DSM-IV) (American Psychiatric Association (APA) 2000). DSM-IV describes a specific phobia as a "marked and persistent fear that is excessive or unreasonable, cued by the presence or anticipation of a specific object or situation" (APA 2002 pp. 157-159).

As the latest version of DSM, DSM-5 (American Psychiatric Association, APA 2013), was not yet published when this thesis was initiated, we have applied the criteria of DSM-IV in assessing childbirth-related specific phobia and PTSD.

According to Wijma and Wijma (2016) in clinical practice, FOC can be divided into four categories of severity:

1) Low FOC: the woman has almost no worry about giving birth;

2) Moderate FOC: the woman has troublesome thoughts about giving birth, but expects that she can handle the problem;

3) Severe FOC: the woman's FOC is so intensive, that it interferes with her private, social and working life and influences her willingness to be pregnant and/or ability to give birth;

4) Phobic FOC: the woman suffers from a paralyzing fear that meets the criteria of specific phobia according to DSM-IV (APA 2002). 
FOC can be assessed in different ways. In obstetric care, staff usually evaluate FOC by means of a short individual interview. When psychiatrists or clinical psychologists examine FOC they often use a structured clinical interview, guided by the criteria of e.g. a psychiatric diagnostic system like the DSM. In clinical research, self-report instruments are used for measuring prevalence and severity, but nowadays these even appear as screening- and assessment instruments in the clinical practice.

Today, the instrument that in many countries is used for measuring FOC is the Wijma Delivery Expectancy/Experience Questionnaire (W-DEQ) (Wijma, Wijma \& Zar 1998), both for research and screening. In this thesis, when we refer to the measurement of FOC in our studies, the assessment is performed with the W-DEQ. The W-DEQ will be described in detail in the section Material and methods, part 3.2.

\subsubsection{Definition and assessment of childbirth related PTSD}

Women with childbirth-related symptoms of posttraumatic stress may meet the criteria of PTSD, i.e. childbirth-related PTSD. According to DSM-IV (APA 2002 pp. 160-162), the diagnostic criteria that have to be met for a diagnosis of PTSD are: the stressor criterion (criterion A), i.e. a self-experienced or witnessed traumatic event, that is responded to with intense fear or horror; symptoms of re-experiencing the traumatic event (criterion B); symptoms of avoidance of stimuli associated with the event and numbing of general responsiveness (criterion $\mathrm{C}$ ); and symptoms of increased arousal (criterion D). The duration of the symptoms has to be more than one month (criterion E), and the disturbance has to cause a significant distress or impairment in social, occupational, or other important areas of functioning (criterion F).

Even women who do not fulfil the diagnostic criteria of PTSD can have highly distressing symptoms that negatively influence their everyday life and, when the stressor is a delivery, even the mother-child relationship (Ayers, Eagle \& Waring 2006; Ayers, Harris, Sawyer, Parfitt \& Ford 2009). In this thesis, such women with high levels of posttraumatic stress symptoms will be referred to as women with symptoms of PTSD.

In obstetric care, childbirth-related PTSD is explored by means of an 
interview, mostly conducted by obstetricians on a specialist antenatal care unit in two situations: when a pregnant parous woman refuses to give birth vaginally, and expresses her fear for the approaching delivery due to an earlier traumatic delivery or another traumatic event like sexual abuse; or postpartum when a woman mentally suffers from a traumatic delivery.

In a consultation with a psychiatrist or clinical psychologist, PTSD is mostly examined by means of a clinical interview, structured according to the criteria in a psychiatric diagnostic system like the DSM.

In research, PTSD and symptoms of PTSD are mostly estimated by means of a structured clinical interview or self-report questionnaires. In the studies included in this thesis, symptoms of childbirth related PTSD were measured with the Traumatic Event Scale (TES) in the version with childbirth as specified traumatic event (Wijma, Söderquist, Wijma 1997). The TES is a self-reported measurement for traumatic events, developed in accordance with the DSM-IV criteria for PTSD (for more details see Material and methods 3.2). In addition to the TES we also used the Impact of Event Scale-Reversed (IES-R) (Weiss 2007) to measure self-reported PTSD symptoms.

\subsection{Prevalence and related factors}

In order to give the reader an idea of the impact of childbirth-related anxiety on the society, a short description will be given of the magnitude of the phenomenon, as well as of various aspects related to the problem.

\subsubsection{Prevalence of FOC}

Fear of childbirth can vary from almost no fear at all to a severe phobia of childbirth. Therefore a definition of the measurement of FOC is essential when the prevalence of FOC is presented. When assessed with the W-DEQ A, the level of FOC is normally distributed in samples of both nulliparous and mixed (borth nulliparous and parous) pregnant women (Zar 2001; Rouhe et al. 2009). For clinical purposes, it is relevant to relate the level of FOC to the extent that the fear contributes to the woman's dysfunction and suffering (Areskog, Uddenberg \& Kjessler 1981; Wijma \& Wijma 2016). 
As studies in this field have used different ways of measuring FOC, it is problematic to compare figures on prevalence from various studies. When FOC is operationalized psychometrically and measured with the W-DEQ A, the prevalence of severe FOC (W-DEQ A sum score $\geq 85$ ) varies between 4.8 and $11 \%$ in mixed samples in Western countries (Zar 2001; Kjaergaard, Wijma, Dykes \& Alehagen 2008; Lucasse, Schei \& Ryding 2014; Toohill et al. 2014b), while the observed prevalence of phobic FOC (W-DEQ A sum score $\geq 100$ ) varies between 2.4 and $8.1 \%$ (Zar, Wijma \& Wijma 2001; Rouhe, Salmela-Aro, Toivanen, Tokola, Halmesmäki \& Saisto 2013).

\subsubsection{Prevalence of childbirth-related PTSD}

Similar to FOC, and as described above, comparison of figures on the prevalence of childbirth-related PTSD from different studies is problematic, as studies have used a variety of measures of PTSD. It has been shown that childbirth related PTSD symptoms in groups of women after delivery vary from almost none to being present to such an extent that the criteria of PTSD are fulfilled (Ayers, Joseph, McKenzie-McHarg, Slade \& Wijma 2008). A meta-analysis shows that up to $3.1 \%$ of parous women in community samples in Western countries suffer from childbirth-related PTSD (Grekin \& O'Hara 2014). This prevalence can be compared with a lifetime prevalence of PTSD related to other events than childbirth being $5.2 \%$ in the US in the non-pregnant female population (Kessler 2000). It is generally considered that there is a high comorbidity with other psychiatric problems among persons with PTSD, both in treatment samples from psychiatric care and non-selected community samples (Kessler, Sonnega, Bromet, Hughes \& Nelson 1995; Kessler 2000).

\subsubsection{Comorbidity of childbirth-related anxiety}

Women with severe FOC (Ryding, Wirfelt, Wängborg, Sjögren \& Edman 2007; Hall et al. 2009; Rouhe, Salmela-Aro, Gissler, Halmesmäki, \& Saisto 2011; Storksen, Eberhard-Gran, Garthus-Niegel \& Eskild 2012; Lucasse, Schei \& Ryding 2014) as well as women suffering from childbirth-related PTSD (Grekin \& O'Hara 2014; Ayers, Bond, Bertullies \& Wijma 2016) have a clear comorbidity with other mental health problems. Such problems seem to be twice as common in women with 
severe FOC as in women with low FOC (Rouhe et al. 2011). The most common mental health problems for women with severe FOC are anxiety and depression disorders (Zar, Wijma \& Wijma 2002; Rouhe et al 2011). In a mixed sample of pregnant women anxiety disorders were diagnosed in $11 \%$ of women with severe FOC (Zar, Wijma \& Wijma 2002 ), and in $73 \%$ of women with phobic FOC. Mood disorders have been diagnosed in $11.2 \%$ of pregnant women referred to consultation because of fear of vaginal delivery in a Finnish study by Rouhe et al. (2011). Söderquist, Wijma \& Wijma (2006) found that $65 \%$ of women with postpartum PTSD also had depression.

The psychiatric dimension of childbirth-related anxiety as well as its high comorbidity with other psychiatric problems demands diagnostic and therapeutic competence in staff caring for women with these problems.

\subsubsection{Aetiology, vulnerability and risk factors for severe FOC}

The aetiology of FOC is considered to be identical to the aetiology of anxiety problems in general (Wijma \& Wijma 2016). What makes FOC unique in comparison with other strong fears and phobias is that the avoided threatening situation is approaching and is inevitable, and that the woman therefore feels trapped in her situation (Wijma 2003).

There is not always a clear distinction between the terms 'vulnerability factors' and 'risk factors' when different studies are compared. In this thesis we use the term 'vulnerability factors' for associated psychological factors and the term 'risk factors' for associated social and medical factors

Mental health problems, especially anxiety disorders and depression, have been labelled as vulnerability factors for FOC (Zar, Wijma \& Wijma 2002; Hall et al. 2009; Ryding et al. 2007; Storksen et al. 2012; Lucasse, Schei \& Ryding 2014). Women with high levels of trait anxiety seem to be more prone to developing FOC and the aforementioned vicious circle phenomenon (Zar, Wijma \& Wijma 2001; Alehagen, Wijma \& Wijma 2006; Sluijs et al. 2012). Other vulnerability factors associated with FOC are having been a victim of recent and/or earlier 
(childhood) sexual abuse and physical abuse (Heimstad, Dahloe, Laache, Skogvoll \& Schei 2006; Lucasse, Schei \& Ryding 2014; Lucasse et al. 2010), whereas high childbirth self-efficacy (i.e. how the woman perceives her capability to give birth) is consistent with low FOC (Carlsson, Ziegert \& Nissen 2015).

Risk factors for which associations with severe FOC have been reported are low educational level (Laursen, Hedegaard \& Johansen 2008), lack of a social network (Saisto, Salmela-Aro, Nurmi, Halmesmäki 2001; Laursen, Hedegaard \& Johansen 2008; Lucasse, Schei \& Ryding 2014), and dissatisfaction with the partner (Saisto et al. 2001). Some women develop FOC after hearing other women's dramatic stories (Fisher, Hauch \& Fenwick 2006; Melender 2002). Because of their anxiety, women can be especially attentive to and selectively hear dramatic stories (Areskog, Uddenberg \& Kjessler 1984). Anxious women are often vigilant for horrifying stories, and interpret them as warnings that something frightening can happen, whereas women who do not have severe FOC also hear these stories, but interpret them as "just as stories" and therefore do not give them much attention (Areskog, Uddenberg, Kjessler 1984; Wijma \& Wijma 2016). For parous women, risk factors for severe FOC during a future pregnancy seem to be a previous negative birth experience (Nilsson, Lundgren, Karlström \& Hildingsson 2012; Lucasse, Schei \& Ryding 2014), an instrumental delivery (Rouhe et al. 2009; Lucasse, Schei \& Ryding 2014), and an emergency CS (Ryding, Wijma, Wijma \& Rydhström 1998; Rouhe et al. 2009; Nilsson et al. 2012; Lucasse, Schei \& Ryding 2014).

\subsubsection{Aetiology, vulnerability and risk factors for child- birth-related PTSD}

The aetiology of childbirth-related PTSD is similar to the aetiology of PTSD following other traumatic events (Wijma 2006; Ayers, McKenzie-McHarg \& Eagle 2007; Ayers et al. 2016). The unique aspect of childbirth-related PTSD is that the distress does not just affect one person (the woman); it also affects the woman's relationship with her newborn child and her partner. As the obstetric care has the responsibility for the care of pregnant women during pregnancy, birth-giving and the period postpartum, there is a unique opportunity to follow the whole course of childbirth-related PTSD from risk factors, through the event, 
to long-term consequences, even offering a unique possibility to develop a research model for prospective studies on the onset of childbirthrelated PTSD (Ayers 2004).

During pregnancy strongly associated vulnerability factors with childbirth-related PTSD are previous and on-going mental health problems (i.e. especially anxiety and postpartum depression) (Ayers et al. 2016), a prior history of trauma (PTSD) (i.e. especially a history of sexual abuse) and primiparity (Ayers et al. 2016). Furthermore, high levels of negative emotions, a perceived threat and a negative birth experience are associated with PTSD following childbirth (Olde, Van Der Hart, Kleber \& Van Son 2006; Grekin \& O’Hara 2014).

Event-related risk factors during delivery can be for example interventions and complications during pregnancy and delivery as well as poor social support or lack of support from the staff (Ayers et al. 2016). Also, (self-reported) dissociation during delivery has been found to be associated with postpartum PTSD (Ayers et al. 2016).

Maintaining factors postpartum related to the development of PTSD are insufficient support after delivery, maladaptive coping and additional psychosocial stress (Ayers et al. 2004).

The vulnerability factors seem to interact with events during labour and delivery to determine the appraisal of the delivery as traumatic (Ayers et al. 2016). Over time the event factors seem to become less important for the woman, while the individual vulnerability and psychosocial circumstances become more relevant in maintaining the PTSD symptoms (Ayers et al. 2016).

\subsection{Consequences of severe FOC and childbirth-related PTSD}

When advantages of potential interventions for childbirth-related anxiety are considered it is important to identify the negative consequences of the anxiety that could be prevented with the intervention. 


\subsubsection{Consequences of severe FOC}

In mixed samples of nulliparous and parous women, severe FOC is found to be associated with prolonged labour (Sydsjö et al. 2014, Johnson \& Slade 2003), more use of instrumental deliveries (Ryding 1993; Sjögren \& Thomassen 1997), and more pain relief (Sjögren \& Thomassen 1997; Alehagen, Wijma \& Wijma 2006) and CS (Ryding et al. 1998; Gottvall \& Waldenström 2002; Sydsjö et al. 2013; Räisänen et al. 2014; Ryding et al. 2015). In similar samples the aforementioned vicious circle has been reported: the phenomenon of finding women who report high FOC before, during and after delivery (Zar, Wijma \& Wijma 2001; Alehagen, Wijma \& Wijma 2006; Sluijs et al. 2012), which thus augments the woman's risk for experiencing the delivery as traumatic.

\subsubsection{Consequences of childbirth-related PTSD}

The consequences of having childbirth-related PTSD can be severe and can have long-lasting effects on the women's personal life and their relationships with their partner and children (Söderquist, Wijma \& Wijma 2006; Wijma, Saita \& Fenaroli 2010; Ayers et al. 2016). Women with a traumatic experience of childbirth often avoid further pregnancies or wait longer to have the next pregnancy compared with other women (Gottvall \& Waldenström 2002; Czarnocka \& Slade 2000). The traumatic experience affects these women's intimate relations negatively, leading even to sexual problems (Fenech \& Thomson 2014). When pregnant again, they prefer CS as method of giving birth more often than women without childbirth-related PTSD (Waldenström, Hildingson \& Ryding 2006; Pang, Leung, Lau, Chung \& Kwok 2008). There are indications that childbirth-related PTSD can influence the women's attachment to their offspring and the relationship with their partners (Nicholls \& Ayers 2006; Ayers, Eagle \& Waring 2006; Ayers, McKenzie-McHarg \& Eagle 2007).

\subsubsection{Societal consequences of severe FOC}

Previous studies indicate that nulliparous and parous women with severe FOC during pregnancy consume more health care and have a higher risk of a traumatic delivery (Saisto \& Halmesmäki 2003; Söderquist, Wijma \& Wijma 2006) than women with low or moderate FOC, which postpartum implies potential mental problems and consequently more 
extensive further use of the health care system. Even though severe FOC thus can be associated with additional costs to society, no cost of illness studies of severe FOC have been published. A responsible utilization of health care resources requires health-economic evaluations besides clinical outcome-evaluations (Bijen 2012). The objective of a cost of illness analysis is to evaluate the economic burden of a given illness for society as a whole by combining the costs of health care utilization and production losses (Drummond, Sculpher, Torrance, O'Brien, Stoddart 2005 pp. 7-11). The economic cost of a certain illness is presumed to represent the economic benefits of a health care intervention that would eradicate the illness (Tarricone 2006). In the only recent health-economic study on the cost-effectiveness of an intervention for pregnant women with severe FOC (by means of group psychoeducation with relaxation), the extra costs for the intervention were compensated by a higher number of uncomplicated spontaneous vaginal deliveries, fewer CSs and better postpartum wellbeing among those in the intervention group than among the women in the control group (Rouhe et al. 2015a).

\subsection{Interventions}

In Sweden there does not exist a recommendation for obstetric care staff regarding treatment of childbirth-related anxiety. Therefore, knowledge retrieved from treatments of other anxiety problems can constitute the basis for new psychological interventions for childbirth-related anxiety.

\subsubsection{Treatment of anxiety problems}

There exists a consensus that exposure to feared objects or situations is both necessary and sufficient for treating the majority of persons with specific phobias (Barlow 2004 p. 408). In vivo (in reality) exposure to feared situations has been found effective for a wide range of specific phobias (Barlow 2004 p. 409). Studies show that the effects of exposure are robust, irrespective of the duration of treatment and the extent of involvement of the therapist (Barlow 2004 pp. 410-411). Treatment of specific phobias has been done both with groups and in traditional, individual therapy contexts, but also by means of self-help manuals with minimal therapist involvement (Barlow 2004 p. 410). When the effects of in vivo and in vitro (imaginary) exposure are compared, there is evidence that in most patients, vicarious exposure (observational learning, 
i.e. watching another person being exposed) alone is not sufficient to initiate clinically significant changes (Barlow 2004 p. 410).

It is a common practice in treatment protocols to take advantage of technology (like videotapes) as a part of the exposure. Combining cognitive strategies (e.g. psycho-education and cognitive restructuring) with exposure-based therapies has shown to lead to an additional decrease of anxiety both in the treatment of general anxiety and of specific phobias (Craske \& Rowe 1997; Antony \& Swinson 2000, Barlow 2004 pp. 408417).

There is a long tradition of treating PTSD with exposure-based therapies (Barlow 2004 pp. 441-453). To handle avoidance, the main element in maintaining PTSD, exposure is applied in two ways, in vivo and in vitro. In vivo exposure involves mostly, within a prepared situation, returning to the site of the traumatic event, or to situations that initiate the symptoms (so-called trigger points), in order to reduce avoidance and to promote mastery over the memories associated with the event. In vitro exposure, which has the same goal to reduce avoidance and promote mastery, is mostly used when in vivo exposure is not possible, as in cases of abuse (Barlow 2004 p. 443).

\subsubsection{Current knowledge of Internet interventions in the treatment of anxiety problems}

Internet-based cognitive behaviour therapy has been widely tested in the treatment of anxiety disorders and has shown good effectiveness, even over a lengthy period of time (Andersson 2010; Cuijpers, Van Straten \& Andersson 2008a; Gun, Titov \& Andrews 2011).

Many ICBT interventions can be seen as online bibliotherapies with elements of audio, video or interactive files. The modules consist of text chapters, and require minimal (10-15 minutes/week) therapist input, mostly short feedback (Andersson \& Titov 2014b). Other programs, such as Interapy (Lange et al. 2003), have more text exchange over the Internet and therefore require more therapist involvement. There are also real-time, chat-based Internet treatments, with continuous therapist input (Kessler et al. 2009). Studies show that therapist guidance generates greater effects than unguided programs (Andersson 2009). So far, 
there is no evidence that the highly technological solutions to supply therapy are more effective than the self-help texts (Bergström et al. 2010; Hedman, Ljóttson \& Lindefors 2012).

The components of an Internet intervention are similar to those of traditional CBT, but are provided over the Internet. Assessing the client's problems before starting of the treatment is an important part of an Internet intervention, in order to decide whether or not the treatment is suitable for the client. According to CBT principles, a central part of the treatment is to follow its effects, which can be done through weekly assessments by questionnaires (Hedman, Carlbring, Ljótsson \& Andersson 2014). It is recommended to use semi-structured diagnostic interviews before the start of a treatment, preferably at a live appointment, but these can also be done over the telephone or via a video meeting. The correct pre-treatment assessment of the individual's problems is important in order to find an appropriate treatment, as the modules cannot be changed during the therapy in contrary to non-standardized treatments. It is often recommended that the inclusion criteria for Internet treatments are the same as for ordinary psychological therapies, with the addition that the person needs to be able to read and write the language used in the therapy, and needs to have access to the Internet (Hedman et al. 2014).

The rationales for the therapy, and advice on the behavioural changes needed to achieve the anticipated effect, are given in the written modules once a week using an encrypted e-mail system, normally over 8-15 weeks. The modules always comprise homework. The homework is the most important part of CBT, with the function of stimulating the client to start and consolidate her behavioural changes. All through the therapy the client has her own therapist, mostly a clinical psychologist or someone with therapist competence, who gives feedback on the reported work during the past week. The therapeutic contact between the client and the therapist takes place completely in the encrypted e-mail system, without any real-time contact (Hedman et al. 2014). To promote compliance, reminder SMS-messages or short telephone calls can be used in between sessions. After completed therapy, it is customary to have a follow up, for example over the telephone (Hedman et al. 2014). The existence of support and feedback from a therapist has been seen to diminish dropouts and to correlate positively with the effect of the 
treatment (Johansson \& Andersson 2014). It is important that the therapist is familiar not only with the treatment method but also with the treated problems (often psychiatric disorders) and eventual comorbidity, as during the therapy even complex clinical matters can appear regarding the client's mental state, her psychiatric condition or other on-going treatments (as medication). It is also important that the therapist evaluates the potential for improvement of the protocols used, which is another essential reason why therapists need to have adequate theoretical and clinical competence.

\subsubsection{Treatment of severe FOC and childbirth-related PTSD in obstetric care}

As stated earlier, the obstetric care in Sweden has no specific recommendations for treatment of severe FOC or childbirth-related PTSD. As the degree of FOC can appear as a continuum from almost no fear to a severe mental illness, the needs of interventions vary accordingly. In Sweden, 98\% of pregnant women follow the antenatal care program offered to all pregnant women (National Board of Health and Welfare 2015). As the majority of the pregnant women express low to moderate FOC, it makes sense that most of them cope well during pregnancy and delivery, supported by their own antenatal care midwife whom they meet several times during pregnancy. When pregnant women express troublesome thoughts about delivery or a wish for a CS, most women are referred to support teams for women with childbirth-related difficulties, often FOC. The goal of such teams is to support the pregnant woman in her troublesome considerations, guide her through pregnancy, and prepare her for birth-giving, irrespective of mode of delivery (Ryding, Persson, Onell \& Kvist 2003; Larsson et al. 2015). Most often pregnant women with FOC pay 1-4 visits to a support team (Ryding et al. 2003; Sydsjö, Sydsjö, Gunnervik, Bladh \& Josefsson 2012; Larsson, Karlström, Rubersson \& Hildingsson 2015). Concluding from the organization of the existing support teams, their psychological/psychiatric competence and the number of visits, these contacts are more supportive than psychotherapeutic. In this thesis these visits to support teams considered as a part of ordinary antenatal care (care as usual). 


\subsubsection{Current knowledge of interventions with therapeutic elements in obstetric care}

Trials on the effect of interventions on FOC in obstetric care are limited. It is therefore impossible to conclude which kind of treatment should be recommended for the treatment of severe FOC or childbirth related PTSD. Moreover, the aim of most studies limits or prioritises improvement of women's motivation to choose a vaginal delivery.

The need for therapeutic interventions was identified already some decades ago. In 1993, Ryding studied the effect of individual short-term psychotherapy in a mixed group of 33 women demanding CS (85\% were parous). The results after the intervention showed that almost half $(14 / 30)$ of the women, wishing a CS and with absence of a medical reason, changed their mind and were delivered vaginally without complications, and all apart from one person (suffering from serious psychiatric illness) had a positive delivery experience. In this study, the level of FOC was not measured.

In a randomized controlled trial, a Finnish research group has studied several aspects of a psycho-education involving relaxation in a group (the LINNEA project) (Rouhe et al. 2013; 2015a; 2015b) with pregnant women suffering from phobic FOC (W-DEQ A sum score $\geq 100$ ). Half of the participants were offered treatment in a group and half followed their ordinary antenatal care program including the possibility of psychosocial support. The protocol comprised six group sessions during pregnancy, and two postpartum follow up meetings, one with a psychologist, and another with a midwife. In three reports from the RCT, Rouhe et al. $(2013 ; 2015 \mathrm{a} ; 2015 \mathrm{~b})$ showed that women in the treatment group had more spontaneous vaginal deliveries, a lower prevalence of CSs, and lower levels of FOC postpartum as measured with the W-DEQ $\mathrm{B}$ than women in the control group. The women in the psychoeducation group also had fewer depressive symptoms postpartum and a better maternal adjustment than the women in the control group. In an additional study from this trial, Salmela-Aro et al. (2012) showed that the intervention increased the preparedness for the transition to motherhood and the motivation to parenthood among women with severe FOC in the psycho-educational group compared with the control group. The increased preparedness for the transition to parenthood was seen as a 
mediator between the observed decrease of FOC (W-DEQ A sum score) and the later experience of a positive parenthood (measured with the Maternal Adjustment and Maternal Attitudes Scale, MAMA) (SalmelaAro et al. 2012).

An Australian research team studied antenatal psycho-education in a group of pregnant women, having a W-DEQ A sum score $\geq 66$. (Toohill et al. 2014b) All received a decision-aid booklet on mode of delivery. Half of the participants were randomized to two simple telephone counsellings at 24 and 34 weeks of pregnancy, conducted by midwives. The other participants had the possibility to study the booklet by themselves. When FOC was measured at 36 weeks of pregnancy, counselling was associated with lower FOC, as measured with the W-DEQ A, and higher self-efficacy in the pregnant women receiving the extra counselling than in women only reading the information booklet without the telephone contact. This study design neither revealed the effect of the intervention on women with $\mathrm{W}$-DEQ A sum score $\geq 85$, nor reported the effect of the intervention on the participants' FOC postpartum.

Until lately, debriefing interventions were frequently used postpartum in women with potentially traumatic delivery experience of the delivery, in order to prevent PTSD. Bastos, Furuta, Small, McKenzie-McHarg \& Bick (2015) analysed in a Cochrane database review eight publications on debriefing after a traumatic delivery. They concluded that there is little or no evidence to support neither a positive nor an adverse effect of psychological debriefing in order to prevent psychological trauma in birth-giving women. The Cochrane review also suggests that improved emotional care from health professionals may be needed in some delivery settings with high rates of obstetric interventions to reduce the risk of experiencing giving birth as traumatic (Bastos et al. 2015).

Eye-movement desensitization and reprocessing (EMDR) for the treatment of childbirth-related PTSD has been described in one pilot study (Sandström, Wiberg, Wikman, Willman, \& Högberg 2005) as well as in one case study (Stramrood et al. 2012). The EMDR method (Shapiro \& Maxfield 2002) consists of a structured treatment concept for traumatic experiences. In the pilot study of Sandström et al. (2005), all four participants reported a reduction of PTSD symptoms. In the case study of Stramrood et al. (2012), the three participants had reduced levels of 
PTSD symptoms after treatment. According to Barlow (2004 pp. 447450), studies of PTSD in general show that the effects of EMDR are not better than those of already existing treatment methods that on the contrary have a good integration with existing psychological models of psychopathology and psychotherapy.

Clinical psychologists and psychotherapists, meeting pregnant women with a childbirth phobia or women suffering from traumatic childbirth experiences, have used cognitive behaviour therapy (CBT). There are no trials reporting on such treatments, but two case reports suggest the feasibility of using CBT in such situations (Ayers, McKenzie-McHarg \& Eagle 2007; Petit 2015). 


\section{AIMS AND RESEARCH QUESTIONS}

\subsection{Aims of the thesis}

The aims of this thesis were:

-To study the prevalence of severe fear of childbirth (FOC) in pregnant women in Sweden and to analyse variables related to severe FOC and to preferred mode of delivery.

-To calculate the cost of illness of severe FOC in Swedish women giving birth to their first child.

-To develop an Internet-based self-help therapy (ICBT) for the treatment of severe FOC and to evaluate its feasibility for the treatment of nulliparous women with severe FOC.

-To improve the understanding of how ICBT may influence nulliparous women's appraisals of the imminent childbirth as explored through their narratives before and after ICBT in late pregnancy.

-To evaluate the feasibility and the therapy effect of an Internet-based trauma-focused self-help program for the treatment of women with posttraumatic stress symptoms following childbirth. 


\subsection{Research questions}

The following research questions were derived from the aims to be examined in the Studies 1-5 and reported in Papers I-V:

1 What is the prevalence of severe FOC in Swedish pregnant women? (Study 1, Paper I)

2 How is severe FOC related to education, maternal age, gestational age, parity and preferred mode of delivery? (Study 1, Paper I)

3 What is the cost of illness of severe FOC in Swedish women giving birth to their first child? (Study 2, Paper II)

4 What is the feasibility of an Internet-based therapist-supported selfhelp program based on cognitive behaviour therapy to treat severe FOC in nulliparous pregnant women? (Study 3, Paper III)

5 How do nulliparous pregnant women with severe FOC describe their expectations of the imminent delivery before and after treatment with Internet-based cognitive behaviour therapy (ICBT)? (Study 4, Paper IV)

6 Is Internet-based cognitive behaviour therapy feasible for treating women with posttraumatic stress symptoms following childbirth? If so, what is the effect of the therapy? (Study 5, Paper V) 


\section{MATERIAL AND METHODS}

\subsection{Ethical approvals}

Studies in this thesis were performed according to the Helsinki declaration.

This thesis has received four ethical approvals; the study protocol for Study 1 was approved by the Regional Ethical Review Board in Stockholm (Dnr 2006/354-31). Study 2 was approved by the Regional Ethical Review Board in Linköping (Dnr 2012-375-31) and registered in Clinical Trials (ClinicalTrials.gov ID: NCT02266186). Studies 3 and 4 were approved by the Central Ethical Review Board of Sweden (Dnr 182011). The Regional Ethical Review Board in Linköping approved Study 5 (Dnr 2013/459-31).

\subsection{The measurements used in the studies}

The psychological questionnaires used in the studies were chosen in order to measure FOC and childbirth-related PTSD, along with measures of general anxiety and depression, and quality of life. The applied questionnaires will be described in detail.

Wijma Delivery Expectancy/Experience Questionnaire (W-DEQ) (Wijma, Wijma \& Zar 1998) is a self-assessment scale to measure FOC, validated for Swedish-speaking nulliparous and parous women. It can be used to assess FOC but also to follow the level of FOC over time. The scale includes 33 statements about childbirth; each statement is rated from "not at all" (zero) to "extremely" (five). Sum scores can vary from zero to 165 . The higher the score, the more severe is the FOC. WDEQ version A measures FOC before and during pregnancy, W-DEQ version $\mathrm{B}$ measures postpartum FOC and is used in connection to a delivery. The Cronbach's alpha in a previous study was 0.89 (Wijma, Wijma \& Zar 1998).

A W-DEQ sum score $\geq 85$ is applied as a cut-off for severe FOC, and a sum score $\geq 100$ for phobic fear (Wijma, Wijma \& Zar 1998; Zar, Wijma \& Wijma 2001). In comparison with a diagnostic interview as the golden standard, a cut-off sum score $\geq 85$ gave a sensitivity of $91 \%$, 
a specificity of $96 \%$ and Likelihood Ratio of 5.4 to find women with severe FOC in a sample with a prevalence of severe FOC of $11 \%$ and phobic FOC of 2.4\% (Zar 2001). W-DEQ A and B were used in Studies $1-4$ as screening tools, as well as for the weekly measurements of the level of FOC during therapy and at follow up.

Hospital Anxiety and Depression Scale (HADS) (Zigmond \& Snaith 1983 ) is a self-report questionnaire developed to assess the presence of anxiety and depression in patients in somatic health care. HADS consists of 14 items, seven items for each subscale; HADS-D (depression) and HADS-A (anxiety). Each item is scored between 0 and 3, stating how often the person, during the previous week, has felt in the specific way. A person can have sum scores between 0 and 21 on each of the subscales. The sum scores above 11, on either of the two subscales, are seen as clinically important signs of anxiety and depression respectively. The mean Cronbach's alpha in previous studies has been 0.83 for HADS-A and 0.82 for HADS-D (Bjelland, Dahl, Haug \& Neckelmann 2002). The sensitivity and specificity for the two subscales, when compared to the General Health Questionnaire (GHQ), were around 0.80 (Bjelland et al. 2002). HADS was used in Study 3 at inclusion to assess symptoms of anxiety and depression.

Traumatic Event Scale (TES) (Wijma, Söderquist \& Wijma 1997) is a self-assessment measure for traumatic events, which has been developed in accordance with the DSM-IV criteria for PTSD. Thus, the subjects can be screened for PTSD by means of the same criteria as in DSM-IV (APA 2000). We used the version of the TES specific for childbirth as the traumatic event. TES can be used as a dichotomous scale to diagnose PTSD (including all criteria A-F of PTSD), or as a continuous scale using a sum score of the 17 questions concerning symptoms questions (criteria B-D) in order to assess the frequency of traumatic stress symptoms (Wijma, Söderquist \& Wijma 1997). The scale consists of 24 questions, with four questions for criterion A, 17 symptom frequency questions for criteria B-D, and one question for time since the trauma (criterion E), and finally one question on the impact of the experiences of trauma on everyday life (criterion F). All questions for criteria B-D are followed by four answer alternatives concerning frequency, giving 0-3 points respectively. The symptom sum score (criteria B-D) can thus vary between 0 and 51. A cut-off symptom 
score of $\geq 30$ is recommended for estimating a PTSD diagnosis when TES is used as a screening instrument (Wijma, Söderquist \& Wijma et al. 1997).

By means of a diagnostic interview as the golden standard for the PTSD diagnosis, a preliminary validation of the TES symptom sum score $\geq 30$ showed a Cronbach's alpha 0.92 with a sensibility of $94.4 \%$ and a specificity of $84 \%$, and for TES as a diagnostic tool a sensitivity of $83 \%$ and specificity of $96 \%$ with a kappa coefficient of 0.81 In the study sample the prevalence of a PTSD diagnosis was 2\% (Spånghagen 2010).

The TES was used in Study 5 as a diagnostic tool to assess PTSD at inclusion and post-treatment, and to follow the participants' PTSD symptoms (symptom scores) weekly. In Study 5 the scores for criteria A $\mathrm{E}$ and $\mathrm{F}$ were assessed only at inclusion.

Impact of Event Scale-Reversed (IES-R) (Weiss 2007) is a self-report measure, comprising 22 trauma-related statements, divided into three subscales: avoidance, intrusion and hyper-arousal, mostly following the DSM-IV criteria. Each item is followed by five answer alternatives on the frequency of symptoms, giving 0-4 points each. The cut-off score $\geq$ 33 is used for the estimation of a PTSD diagnosis. In a community sample the Cronbach's alpha was 0.96 , and, depending on the time since the trauma and other factors, the test-retest correlation was 0.5-0.89 (Weiss 2007). The IES-R was used in Study 5 to measure self-reported symptoms of posttraumatic stress at inclusion and at the post-treatment follow up.

Beck Depression Inventory-II (BDI-II) (Beck, Steer \& Brown 1996) is a self-report measure for assessing depression symptoms. It can be used to measure the severity of depression, but also to follow change in symptoms. It consists of 21 items with 4-point (0-3) scales of the severity of symptoms. Sum scores above 20 indicate moderate to severe depression. Studies in a community sample with women and men show an internal consistency according to a Cronbach's alpha of 0.93 and a testretest reliability of 0.77 (Furlanetto, Mendlowich \& Bueno 2005). The BDI-II was used in Study 5 at inclusion and in the post-treatment follow up. 
Beck Anxiety Inventory (BAI) (Beck, Epstein, Brown \& Steer 1988) is a 21 item self-report measure of anxiety symptoms with four point scales from 0 ("not at all") to 3 ("very much"). A sum score above 16 indicates moderate to severe anxiety. Beck et al. (1988) found an internal consistency in a non-pregnant community sample, as estimated with a Cronbach's alpha, of 0.92, and a test-retest reliability of 0.75 (Beck, Epstein, Brown \& Steer 1988). The BAI was used in Study 5 to assess symptoms of anxiety at inclusion and at post-treatment follow up.

Patient Health Questionnaire 9 items (PHQ9) (Kroenke, Spitzler \& Williams 2001) is a self-report measure for assessing severity of depression. It consists of nine questions scoring $0-3$, providing a $0-27$ severity score that indicates sensitivity for change. A sum score above 15 indicates depressive symptoms with a need of treatment. The internal consistency according to the Cronbach's alpha in a non-pregnant community sample was 0.94 (Cannon et al. 2007). PHQ-9 was used in Study 5 for weekly measurements of depressive symptoms during the treatment.

Quality Of Life Inventory (QOLI) (Frisch, Cornell, Villanueve \& Retzlaff 1992) is a self-report measure of subjective satisfaction within 16 areas, considered important for quality of life. The measure has 32 items consisting of item-pairs, where the satisfaction is rated on a sixstep scale from -3 to +3 , while the importance of these areas is rated from 0 to 2. The areas reported not to be important are not included in the sum score. The internal consistency as calculated with the Cronbach's alpha was 0.77-0.89 in a non-pregnant community sample; the test-retest reliability was 0.81-0.91 (Frisch et al. 1992). QOLY was used in Study 5 to measure life satisfaction at inclusion and at posttreatment follow up.

EuroQol 5 Dimensions (EQ5D) (EuroQoL group 1990) is a standardized instrument for measuring health outcome, applicable to a wide range of health conditions not connected to a specific diagnosis. It provides a simple descriptive profile and a single index value for health status. The five dimensions included are mobility, self-care, usual activities, pain/discomfort, and anxiety/depression. Each dimension is rated as one of three levels of severity (no problems/some or moderate problems/extreme problems). The health profile is then converted to an index (EuroQoL group 1990). EQ5D was used in Study 5 to measure 
health-related quality of life at inclusion and at post-treatment follow up.

The MINI-International Neuropsychiatric Interview (MINI) The MINI-International Neuropsychiatric Interview version 6.0) (Sheehan et al. 1998) is a brief diagnostic interview developed to determine the presence of current and lifetime Axis I disorders according to the diagnostic criteria from DSM-IV (APA 2000). In our trial of the Internet intervention of childbirth related PTSD symptoms (Study 5) the MINI was accomplished via telephone. The MINI was used to assess the clinical diagnoses of comorbidity, at inclusion and, for both groups, when the (un-postponed) treatment in the treatment group was finished, and in addition for the control group after their deferred treatment.

Telephone interview A short structured telephone interview was conducted in the feasibility studies (Studies 3 and 4) as a complement to the self-report assessments, in order to check that the participant was serious in her intention to participate in the treatment, and was not psychotic or suicidal. In the same studies, a short interview was also conducted as a follow up by telephone with questions about the participants' wellbeing and delivery, and was completed with a W-DEQ B measurement, also by telephone. 
Material and methods

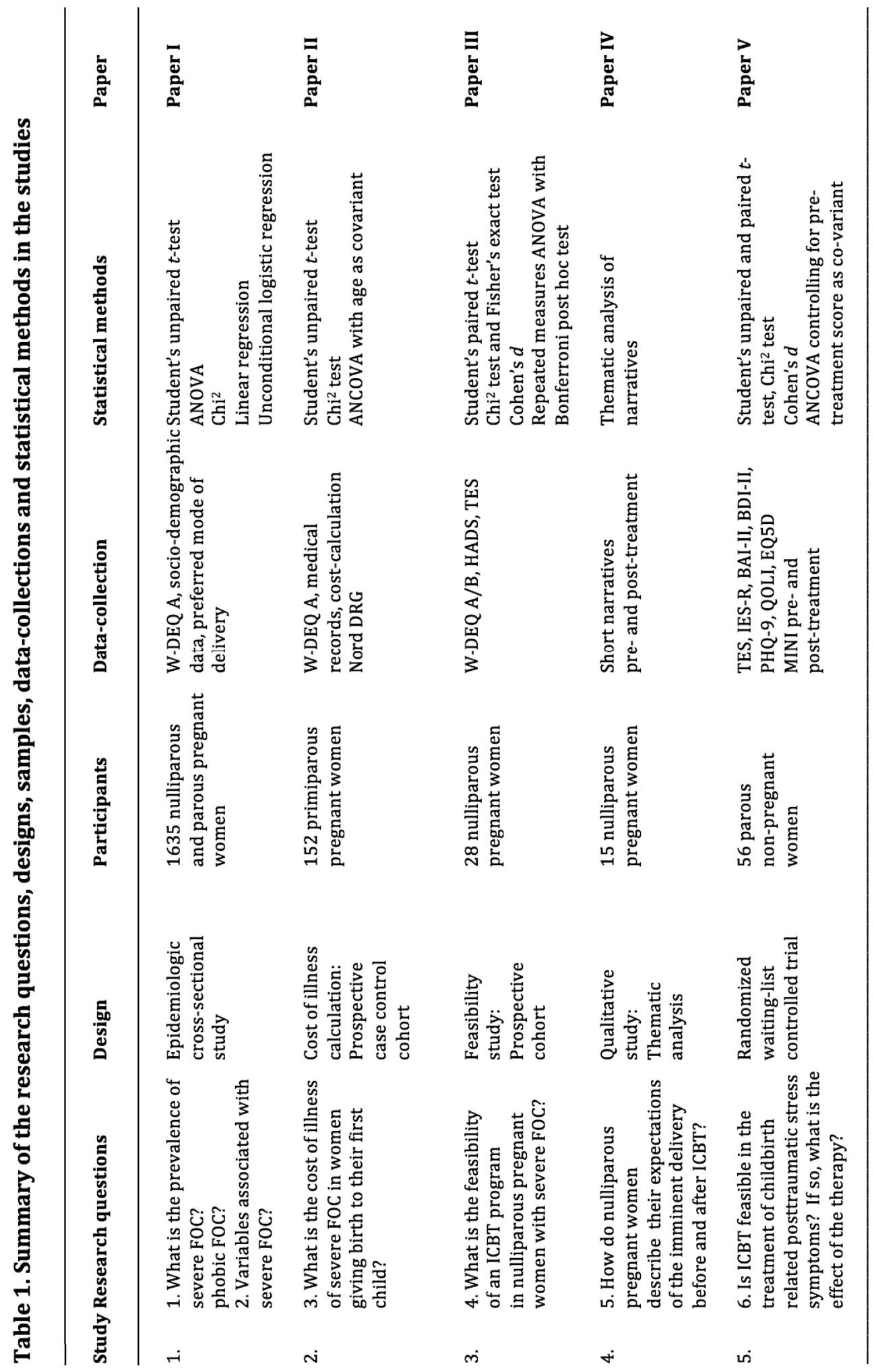




\subsection{Design, procedure and analysis}

The designs, procedures and analysis methods in the studies are summarized in Table1.

\subsubsection{Prevalence of severe FOC and variables related to severe FOC and preference for CS (Study 1, Paper I)}

\section{Research questions 1-2}

What is the prevalence of severe FOC in Swedish pregnant women? How is severe FOC related to education, maternal age, gestational age, parity and preferred mode of delivery? (Study 1, Paper I)

\section{Design and procedure}

We recruited in total 1635 pregnant women (861 nulliparous, 769 parous and five with unknown parity) to a cross-sectional study in order to study the prevalence of severe FOC and variables related to severe FOC. The participants came from four different regions of Sweden (the Northwestern part of Stockholm, Norrköping, Motala and Helsingborg) and were in various stages of pregnancy, attending their ordinary antenatal care unit during September-October 2006. The study protocol included a measurement of FOC (W-DEQ A) and a questionnaire with questions on socio-demographic data, previous obstetric history and preferred way of delivery. The internal drop out varied between 0 and 22. 


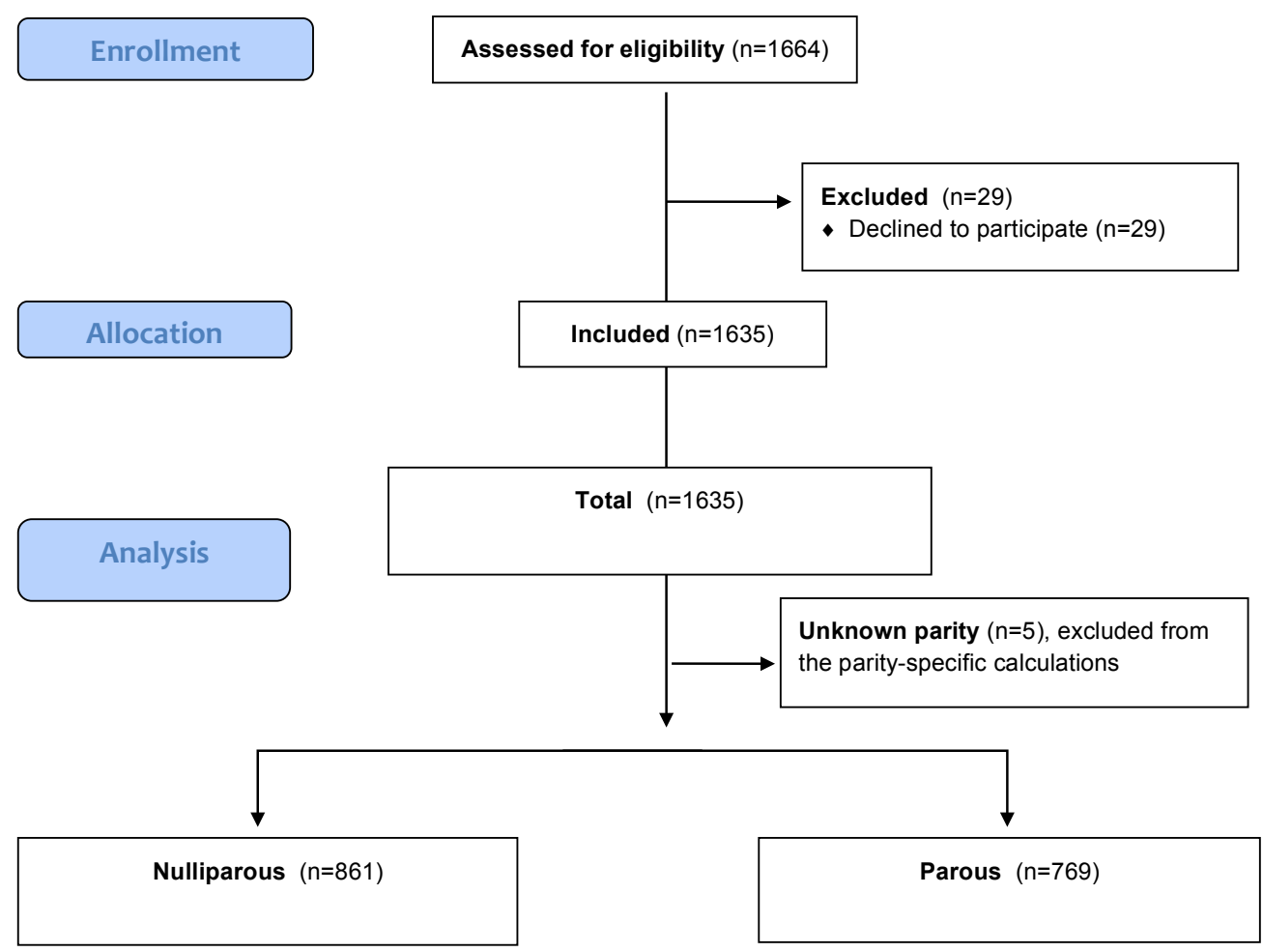

Figure 1. Flowchart of participants in Study1.

\section{Statistical analyses}

Statistical analyses were performed with unpaired $t$-test or analysis of variance (ANOVA) for continuous variables, a $\mathrm{Chi}^{2}$ test for categorical variables and a linear regression analysis for correlation between gestational age and level of FOC (W-DEQ A). Unconditional logistic regression analysis was used to model the risk of severe FOC and preference for CS as a function of maternal characteristics and previous reproductive history. Isolated missing data (less than $2 \%$ ) were replaced with the mean of the existing data of each variable. Nulliparous and parous women were analysed separately. 


\subsubsection{Cost of illness of severe FOC (Study 2, Paper II)}

\section{Research question 3}

What is the cost of illness of severe FOC in Swedish women giving birth to their first child? (Study 2, Paper II)

\section{Design and procedure}

In five different regions of Southern Sweden (Jönköping, Kungsbacka, Lund, Norrköping and Göteborg), we recruited 303 nulliparous women attending their routine ultrasound examination at 18-20 weeks of pregnancy at their ordinary antenatal care clinic between May 2013 and December 2014. The participants filled in the W-DEQ A, offered sociodemographic data and gave their informed consent to the researchers' abstraction of data from the medical records into a protocol three months after the delivery. All obstetric visits to the antenatal and postnatal care system, hours on sick leave, in-patient care, and delivery parameters were mapped during pregnancy, delivery and until three months postpartum. In order to calculate the cost of illness of severe FOC we followed a group of 43 women with severe FOC and compared their costs with those of a group of 107 women with low FOC. We also recorded data from a random sample of 21 women from the excluded group of women with moderate FOC (W-DEQ A sum score 61-84), in order to control for exclusion bias. Figure 2 shows a flowchart of the study. 


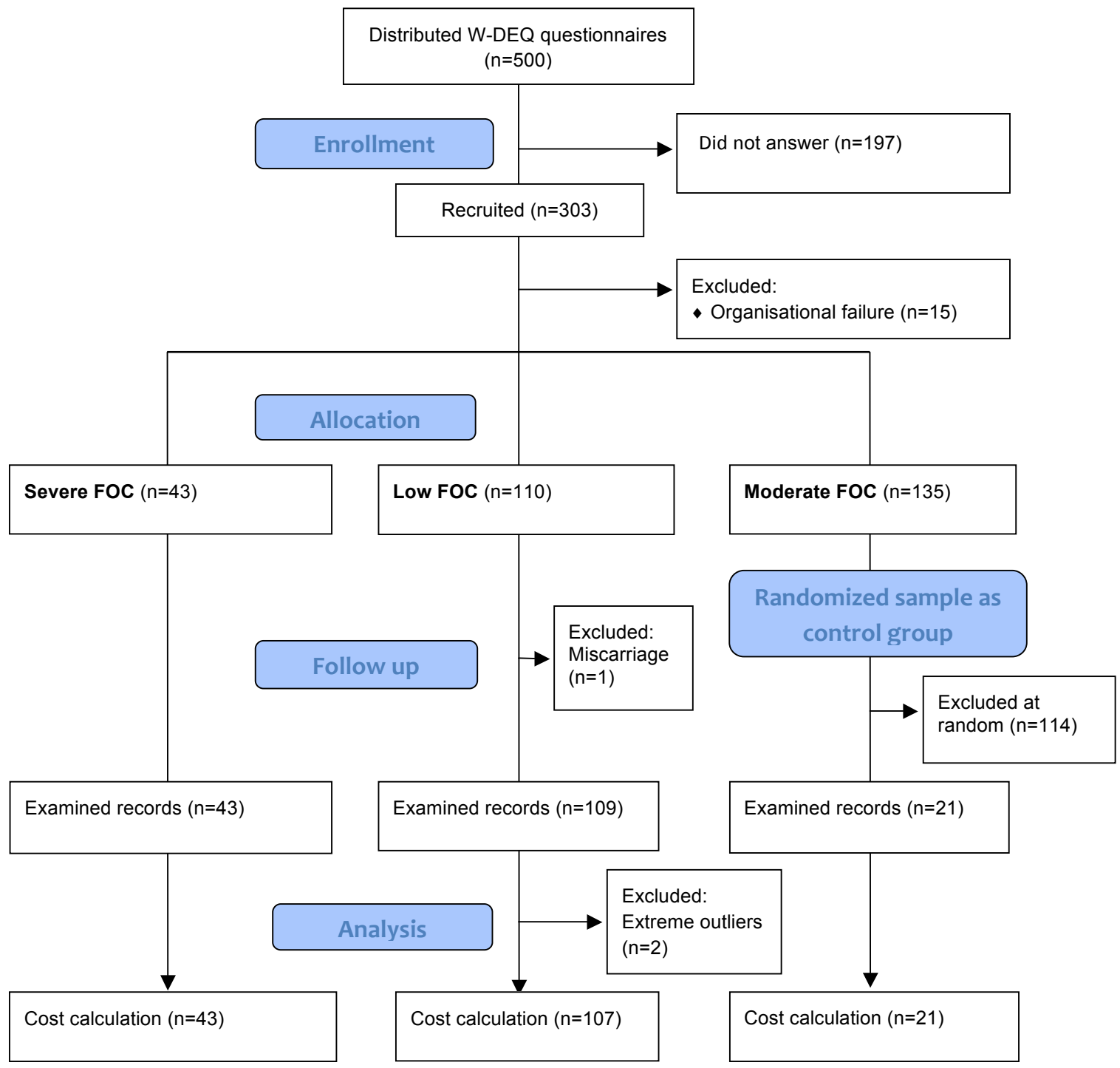

Figure 2. Flowchart of the sampling process in Study 2. 


\section{Statistical analyses}

Statistical analyses were performed with a Student's unpaired $t$-test to compare parametric measurements between the groups. To compare nonparametric measurements between groups we used a Chi ${ }^{2}$ test. Missing values of single items (due to missing parts of the medical record; approximately $2 \%$ ) were replaced with the mean of the existing measurements of each item per group. As the age in the compared groups was significantly different, age-adjusted comparisons of health care efficacy, such as visits, hours on sick leave and medical parameters, were calculated using analysis of covariance (ANCOVA) with age as a covariate. Differences were assumed to be statistically significant at $p<0.05$.

\section{Health economic calculations}

The health economic cost calculations were based on the age-adjusted comparisons. The costs for health care visits and delivery costs were calculated following the outlines for NordDRG (Nordic Diagnosis Related Groups) (Bellanger, Quentin \& Tan 2013; Fetter \& Freeman 1986), using Diagnosis Related Groups (DRG) tariffs for 2014 in the South-Eastern Health Care Region of Sweden. Delivery costs were counted individually for every participant assigned by a "DRG-grouper" program based on diagnoses classified by the International Classification of Diseases, 10th revision (ICD-10) and procedures classified by the Nomesco Classification of Surgical Procedures, a system that takes into account the presence of complications or comorbidities but also the age and sex of the patient. Patients within each category are supposed to be clinically similar and are expected to use the same level of hospital resources. The computerized DRG system is based on the international Health Care Financing Administration version 12 (HCFADRG-12) (Nordic Casemix Centre). The sick leave cost/hour calculation was based on the mean income per month for Swedish women aged 2534 in 2013 , with $31.42 \%$ in taxes and social contribution costs added (Statistics Sweden 2013). 
Table 2. The unit costs for different items taken from the medical records and used in the calculations in Study 2

\section{Antenatal variables}

Visit to antenatal unit midwife (30 min)

Ultrasound (30 min)

Visit to specialized midwife (60 min)

Obstetrician outpatient visit (30 min)

In patient care during pregnancy ${ }^{\mathrm{a}}$ (per day)

\section{Delivery variables}

Spontaneous vaginal delivery -non complicated (per procedure)

Complicated vaginal delivery $\mathbf{b}$ (per procedure)

Non-complicated caesarean section (per procedure)

Complicated caesarean section (per procedure)

\section{Postpartum readmission}

Postpartum in-patient stay a (per day)

Outpatient visit obstetrician (30min)

\section{Indirect costs}

Sick leave (per hour)c $528.8-680.8^{\mathrm{a}}$

227.1

Unit cost ( $€$ )

124.1

146.2

248.2

227.1

$169.4-408.2^{a}$

2642.5

3922.6

5407.5

6681.6

22.1

\footnotetext{
a Depending on Nord DRG 2014.

b Including instrumental deliveries with complications, laserations of $3^{\text {rd }}$ or $4^{\text {th }}$ degree, requiring suturing in the operation theatre, removal of placenta by means of surgical evacuation, or bleeding $>1000 \mathrm{ml}$.

c Calculated with a mean income of $€ 2851$, for Swedish women aged 25 to 34 in 2013 ( $31.42 \%$ in social security contribution costs added).
} 


\subsubsection{Treatment of severe FOC over the Internet (Studies 3 and 4, Papers III and IV)}

\section{Research question 4}

What is the feasibility of an Internet-based therapist-supported self-help program based on cognitive behaviour therapy to treat severe FOC in nulliparous pregnant women? (Study 3, Paper III)

\section{Design and procedure}

We developed an Internet-based self-help therapy manual for the treatment of severe FOC, based on common CBT principles for treatment of anxiety disorders. Information about the project was disseminated by advertisements in national newspapers, articles in regional newspapers, notes in the national midwifery magazine as well as social media, and by a link from the national home page for on-going psychological treatments over the Internet (www.studie.nu) to the project home page.

Thirty women with severe FOC recruited themselves directly via the home page that had been created for the study (www.kbt.info/Frida). We assessed their eligibility for the study before the treatment start, by a short telephone interview (conducted by a research midwife not involved in the treatment). The W-DEQ A was used weekly during the treatment period to follow changes in FOC. Three months after delivery, again using a short telephone interview, we followed up participants' wellbeing and the W-DEQ B was filled in. Participants were anonymous during the project. 


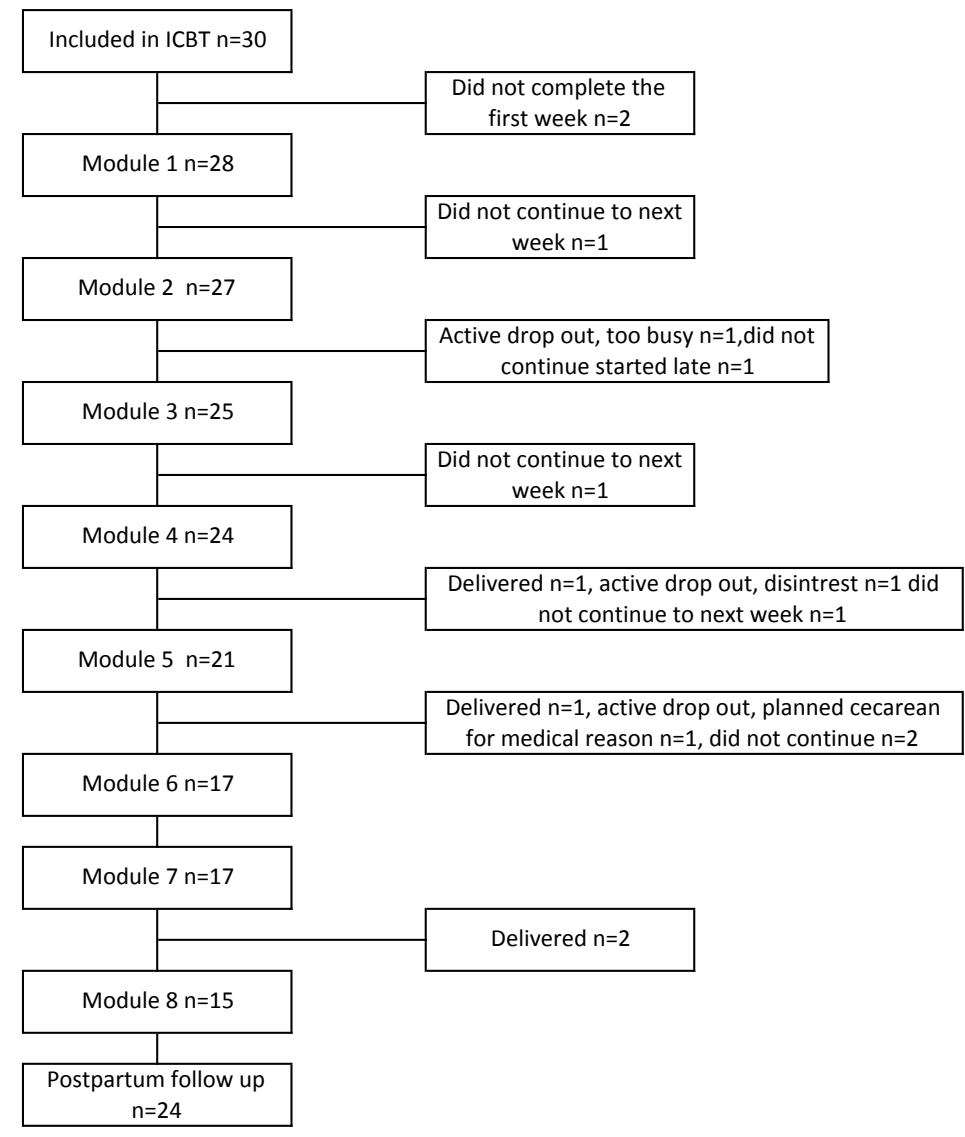

Figure 3. Flowchart of the participants completing the modules in the Internet intervention for the treatment of severe FOC in Study 3.

\section{The intervention - ICBT for the treatment of severe FOC}

The study manual was presented to the participants via the Internet. The manual had eight modules, each module with three parts - an information track, a therapy track and a homework track. The information track comprised the physiology of normal pregnancy, labour and delivery, as well as possible complications and treatments. The therapy track included psycho-education, breathing retraining, cognitive restructuring, exposure in vitro and in vivo, assertiveness training, and relapse prevention. For details see Table 3. Each module included questions about the 
information track and the homework tasks for the following week. Control questions were intended to encourage learning and to enable the research coordinator $(\mathrm{KN})$ to assess whether the participants had assimilated the material. Participants were presented with one module per week and short individual feedback was given every week by a personal therapist, using the project's secure contact management system. The participants were able to contact the therapist using the contact system whenever they wanted. Four MSc psychology students in their graduation class and the research coordinator served as therapists in the project. The recruitment process took more time than planned, which was why, after the first six months with only five participants, the research coordinator continued as the only therapist. 
Table 3. Outlines of the modules in the ICBT program for the treatment of severe FOC in Study 3

Information path

Module $1 \quad$ Normal pregnancy: first trimester

Module 2 Normal pregnancy: second trimester

Module 3 Normal pregnancy: third trimester

Module $4 \quad$ Normal labour: preparations and start

Module $5 \quad$ Normal labour: pain relief

Module $6 \quad$ Normal labour: first and second stage

Module $7 \quad$ Normal labour and delivery: acute situations

Module $8 \quad$ Normal labour and delivery: third stage
CBT path

CBT as treatment method. Psycho-education concerning fear and anxiety in general and FOC especially. How physical conditions (e.g. sleep deprivation, hunger etc.) can influence people? Description of own expectations of the imminent labour and delivery.

Goal setting - what can be realistic to expect during labour and delivery. Participants set their own goals for the therapy. Exposure to other women's stories about labour and delivery.

Instruction in and practice with tools to deal with the physical reactions to fear e.g. breathing retraining, focusing techniques. Testing the tools in everyday situations.

Difference between thoughts and feelings and how they interact. Participants identify and challenge own fearful thoughts and then produce alternative, more helpful thoughts about labour and delivery.

Exposure in vivo (i.e. pictures, films etc).

How to manage situations one cannot influence? What is control? How to control one's own thoughts?

Advantages of different modes of delivery for one's own situation.

Summary of the program.

How to deal with setbacks? Participants work out an individual program for maintaining their progress. Description of own expectations of the imminent labour and delivery. 


\section{Statistical analyses}

Statistical analyses were conducted according to the intention to treatprinciple, bringing the last reported result forward when measuring within group effects. A Student's paired $t$-test was conducted when comparing the W-DEQ sum scores before treatment with the last reported W-DEQ sum scores before delivery. Cohen's $d$ was used to measure the within group effect size. A Chi ${ }^{2}$ test and Fishers' exact test were used to compare nonparametric measurements at inclusion. With a Completed Cases Principle, a repeated measures ANOVA was conducted on the 15 participants who had completed all eight weeks of therapy with a Bonferroni post hoc test to identify the point in the therapy at which a significant change occurred. To minimize type-1 errors, we did not correct for the missing values, and therefore chose to interpret the results more carefully. Differences were assumed to be statistically significant at $p<0.05$. The minimum sample size was determined to $\mathrm{n}=14$ with the following calculation: by applying $80 \%$ power and $p<0.05$ in a sample initially experiencing severe FOC (approximately mean W-DEQ sum score 95), we assumed we would be able to observe a mean reduction of the W-DEQ sum score of around 25 points after the treatment.

\section{Research question 5}

How do nulliparous pregnant women with severe FOC describe their expectations of the imminent delivery before and after treatment with Internet-based cognitive behaviour therapy (ICBT)? (Study 4, Paper IV)

\section{Design and procedure}

In order to improve our understanding of how ICBT may influence participants' appraisals of an imminent childbirth, we collected short written narratives pre- and post-treatment, from 15 of the nulliparous participants belonging to the ICBT treatment program in Study 3. They received a structured task, i.e. to imagine that they were in five different situations during the process of labour and delivery, and then to describe how they imagined these situations (see Table 4). These narratives before (first part of module one) and after the ICBT (last part of module eight) were analysed separately, using thematic analysis (Braun $\&$ Clarke 2006). After this procedure, the pre- and post-treatment narratives were compared to find the domains in which the participants' attitudes might have changed. In total, the written texts amounted to 7957 words. Figure 4 shows the design of the study. 
Table 4. Tasks given to women in order to describe their expectations of the imminent delivery in Study 4

Below follows a short description of some situations during childbirth. After you have read the short description of the situation, start by closing your eyes in order to visualize the situation properly, and then write down your answers to the five questions.

1) Imagine that you have just arrived at the Delivery Ward and you are waiting for the midwife to admit you.

2) You are now in your own delivery room; your are there with your partner or an other support person, nobody else is there.

3) Your contractions are underway. The midwife has just left and after her examination told you that your cervix has dilated $5 \mathrm{~cm}$; there are still some hours to go.

4) You're at the end of delivery; the final contractions are at their most intensive and you're pushing.

5) The baby has just arrived and been placed on your stomach.

For every situation: describe specifically:

-What do you see?

-Who else is in the room?

-What are they doing?

-What happens?

-What are you thinking about?

-What do you feel?

-What are you doing?

-How is the situation developing? 


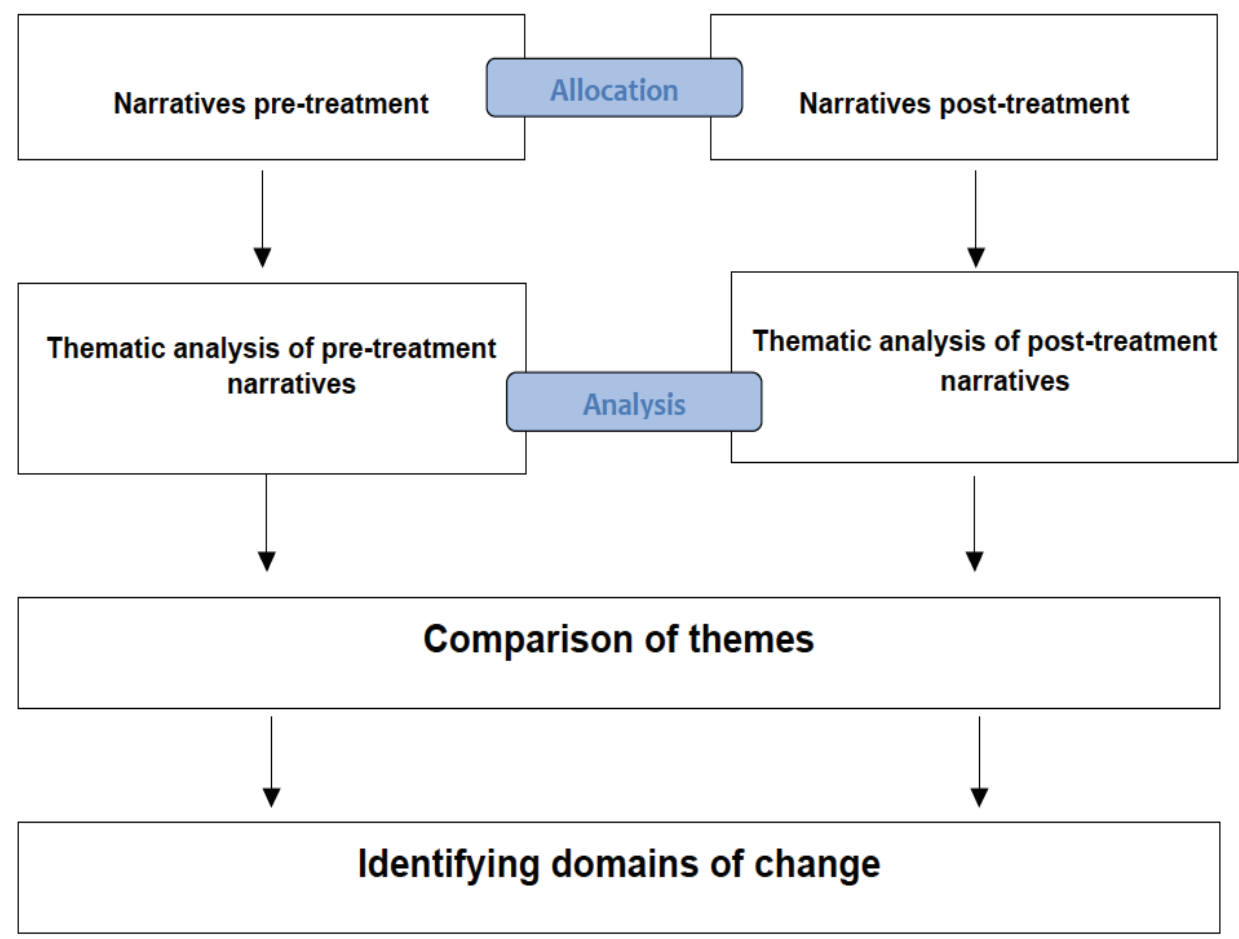

Figure 4. Model of the analysis of the 15 informants' narratives of the imminent delivery in Study 4.

\section{Data analysis}

Thematic analysis, used in this study to analyse the short narratives, is a method for identifying, analysing and reporting patterns (themes) within texts. A theme is considered to capture something important in relation to the research question. According to Braun and Clarke (2006) the thematic analysis method proceeds in six phases:

1) becoming familiar with the data;

2) generating initial codes;

3) searching for themes;

4) reviewing themes;

5) defining and naming themes;

6) producing the report.

In our study the texts were read and reread four times before creating initial codes. These codes were then analysed by searching for and re- 
viewing themes. The narratives before and after ICBT were first analysed separately. Thereafter the pre- and post-treatment narratives were compared to identify the domains where attitudes might have changed. The procedure of generating codes and searching for themes was initially implemented by two persons separately, and then discussed in detail until agreement was reached.

\subsubsection{Treatment of childbirth-related PTSD symptoms over the Internet (Study 5, Paper V)}

\section{Research question 6}

Is Internet-based cognitive behaviour therapy feasible for treating women with posttraumatic stress symptoms following childbirth? If so, what is the effect of the therapy? (Study 5, Paper V)

\section{Design and procedure}

We developed a trauma-focused Internet based CBT manual based on exposure components for childbirth-related PTSD. The components were inspired and partly derived from previous Internet interventions for PTSD (Ivarsson et al. 2014), based on prolonged exposure (Foa Frances \& Davidson 1999) in combination with ideas from narrative exposure (Robjant \& Fazel 2010). During a period of four weeks between the beginning of February and the beginning of March 2014, 56 women were self-recruited directly on the project-specific website (laura.iterapi.se). Information about the study was announced on a website (www.studie.nu), which offers information about participation in Internet-based psychological research trials in Sweden. Advertisements were also placed in national daily newspapers. Information was spread in social media and via local TV stations and the national public service radio. A newsletter was sent by e-mail to all obstetricians and midwives in charge of antenatal clinics in Sweden, to inform the staff, so they could encourage patients to register directly on the homepage. Initially, 101 women showed interest by completing the application form. Of these, 74 filled in the complete registration and were assessed via a telephone-administered diagnostic structured MINI interview. Before inclusion, all candidates were discussed at an intake conference. Finally 56 women that fulfilled the inclusion criteria (see Table 5) were included 
and randomized either to a treatment group or to a control group. The control group started on a waiting list and received their (delayed) treatment when the first group had completed their therapy. The randomization was conducted by an independent person, not involved in the project, using an online true random-number service (www.random.org).

Table 5. Inclusion criteria for the trauma-focused ICBT program in Study 5

(i) Self-reported posttraumatic stress symptoms related to a traumatic childbirth and TES sum score $\geq 30$;

(ii) Age of at least 18 years;

(iii) Access to a computer and the Internet;

(iv) Able to read and write Swedish;

(v) Not being pregnant;

(vi) No problems requiring more urgent care;

(vii) Not currently participating in psychotherapy;

(viii) Not currently having a serious problem that would be better treated with psychiatric care;

(ix) If under medication, having taken the same dose for at least one month, with no intention to change the dose during the course of the program;

(x) Minimum three months since the traumatic delivery. 


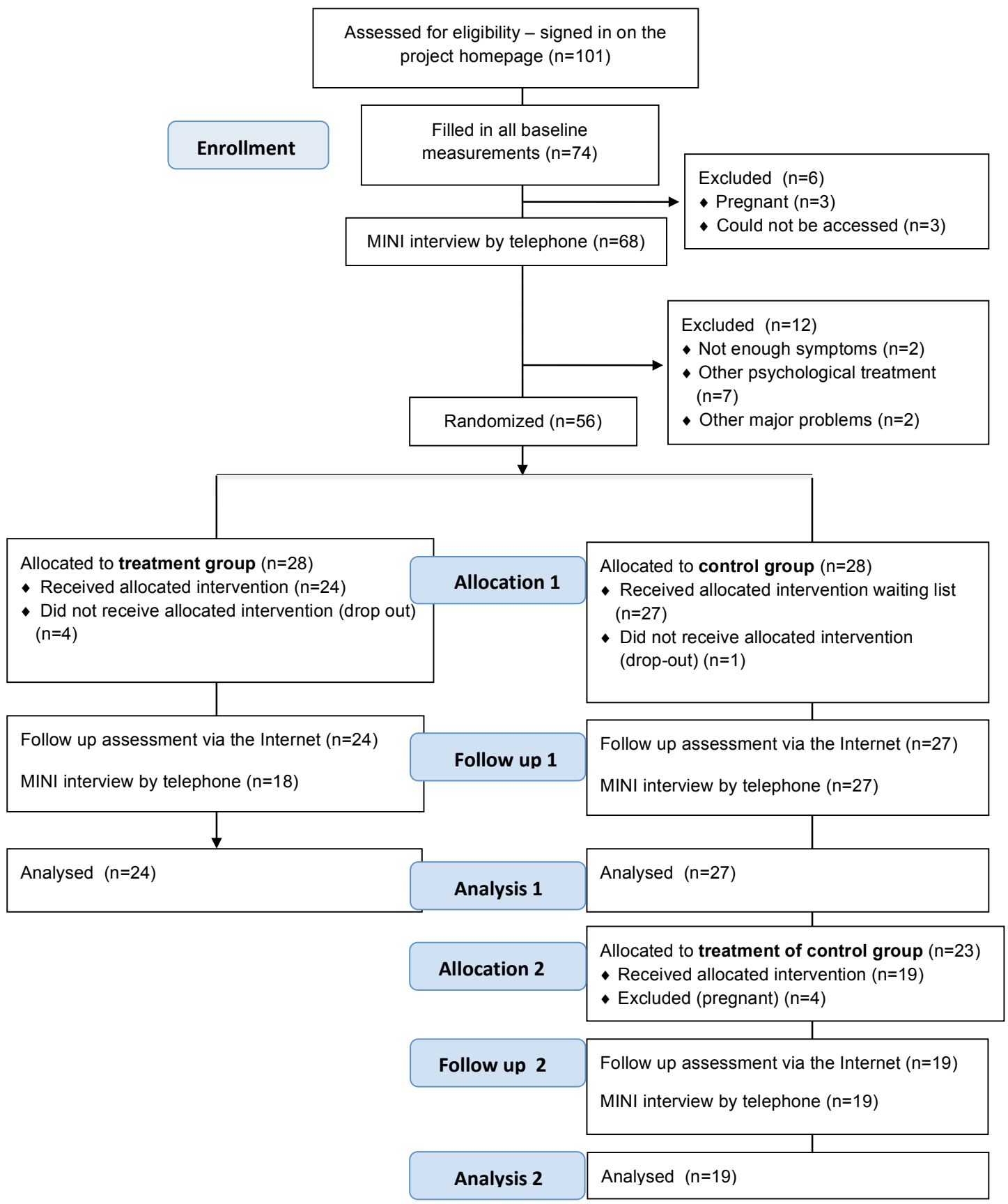

Figure 5. Flowchart of participants and assessments in Study 5. 


\section{Intervention}

The therapy included psycho-education, anxiety coping methods and skill training, imaginary- and in vivo exposure, and cognitive restructuring. The outline of the modules is presented in Table 6. During the therapy the participants were presented with one module per week. Individual feedback was given every week by a personal therapist, using the project's secure contact management system (Andersson \& Titov 2014). At inclusion the participants were asked to prioritize their participation during the treatment period, as the treatment was restricted to eight consecutive weeks. Participants were able to contact their therapist via the contact system whenever they wanted. The therapists in the project were seven MSc psychology students in their final term of a five-year course, and an obstetrician from the project management team. All were subject to continuous clinical supervision and tutoring by one of the seniors in the research team. Weekly during their waiting list period, the control group filled out measurements of the TES and PHQ-9 using the project's secure contact system. The treatments for the two groups were identical during their respective active treatment periods.

\section{Statistical analyses}

Statistical analyses were conducted with an intention-to-treat design in all analyses, meaning that participants were analysed in accordance with their randomization group. Missing data were addressed by a multiple imputation model (Sterne et al. 2009). Differences in sociodemographic data and pre-treatment measures between groups were analysed with independent samples Student's $t$-tests and $\mathrm{Chi}^{2}$ tests. Within-group changes (from pre- to post-treatment) were analysed using paired $t$-tests. The effect sizes (ESs) (Cohen's $d$ ) were calculated using pooled standard deviations. Between-group effects were analysed using univariate analysis of covariance (ANCOVA) while controlling for pre-treatment scores as a covariate (Vickers \& Altman 2001). According to Cohen's standards for research in the behavioural sciences, an ES $d \geq 0.80$ between-group for treatment effects in psychotherapy is considered large, $d=0.80-0.5$ moderate, and $d=0.50-0.20$ small (Spence et al. 2011). Clinical relevance was counted as a change in prevalence of DSM-IV disorders based on the results from the MINI interviews at inclusion and at post-treatment follow up. 


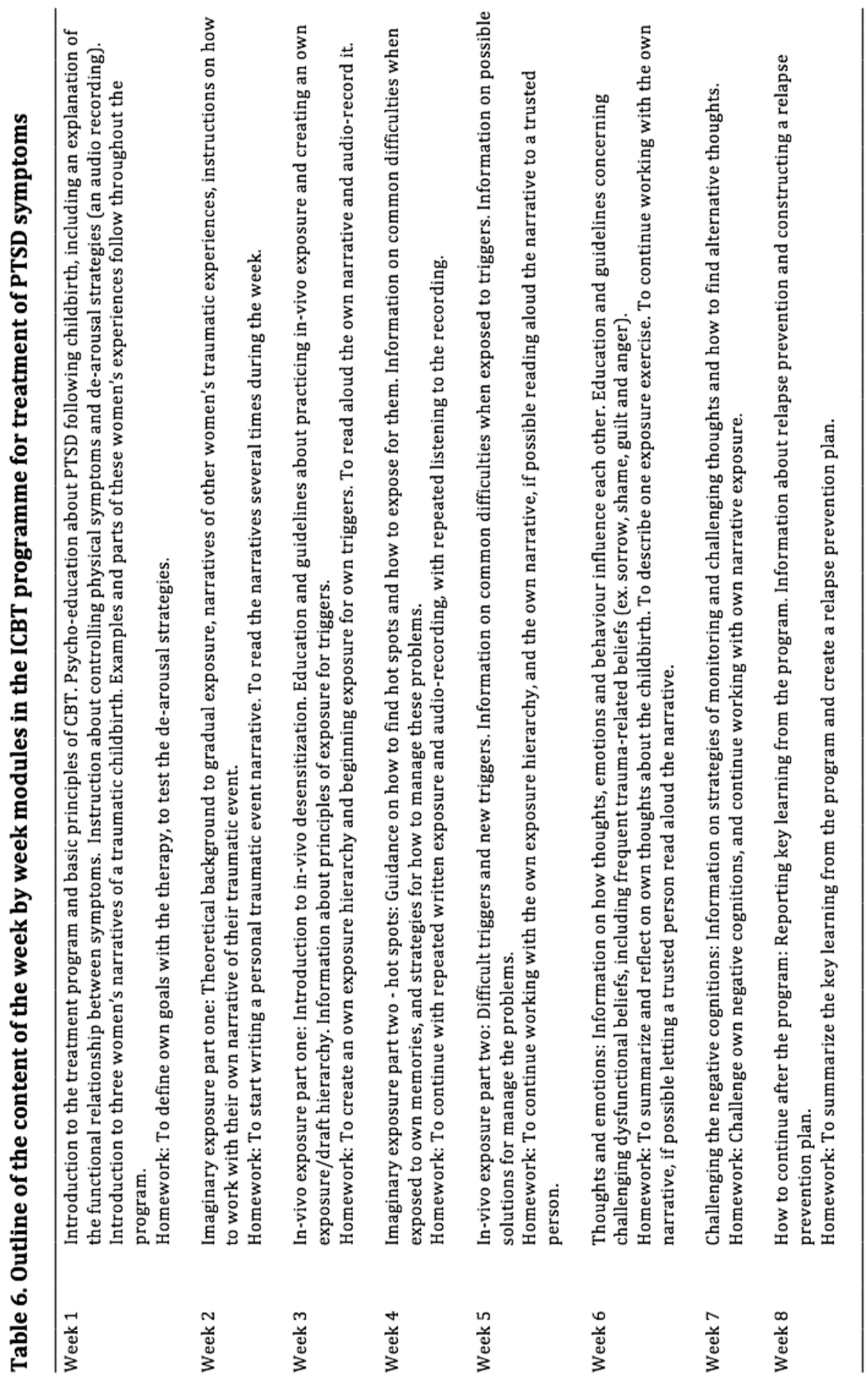




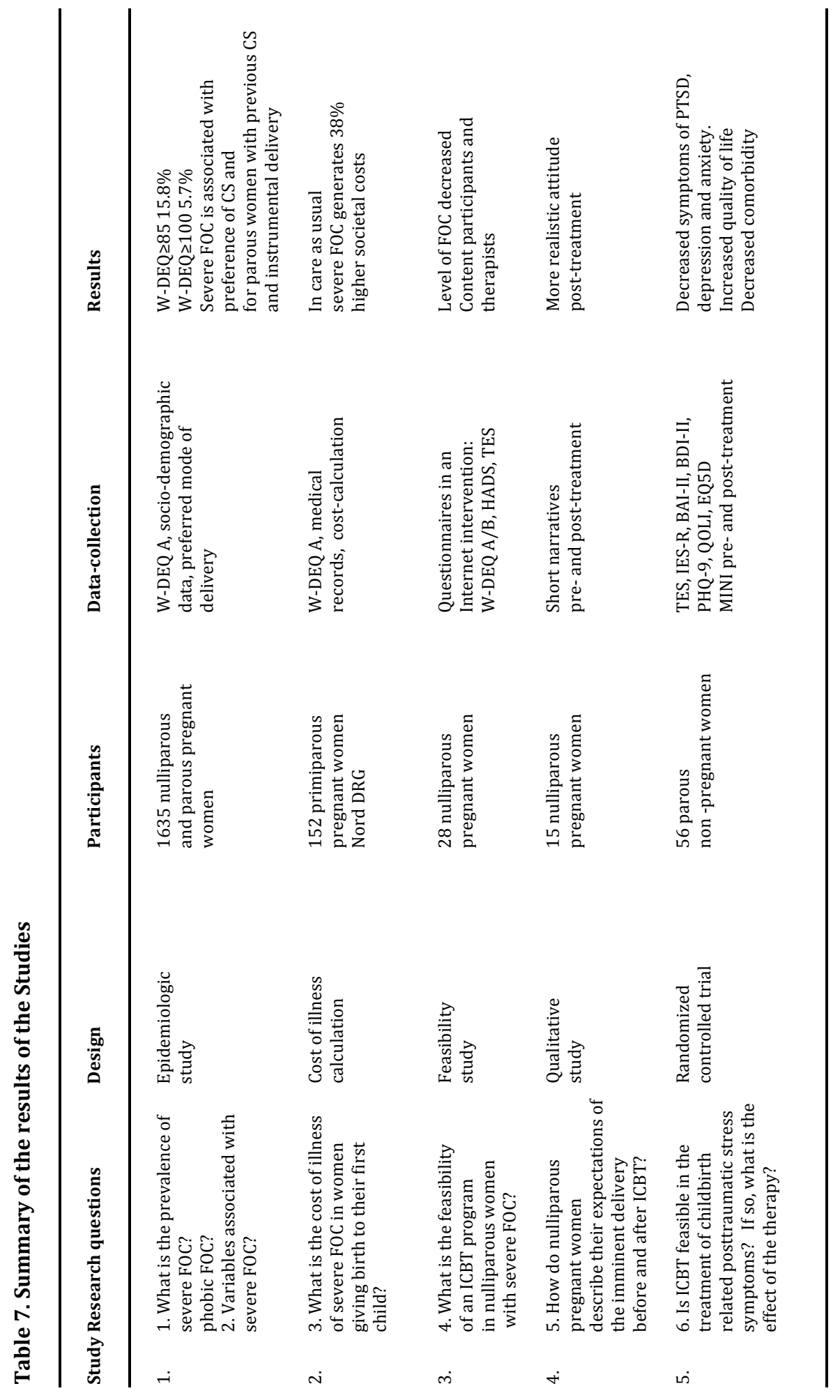




\section{RESULTS}

The main results of the Studies are summarized in Table 7.

\subsection{Prevalence of severe FOC and variables related to severe FOC and preference for CS (Study 1, Paper I)}

\subsubsection{Results corresponding to research question 1}

What is the prevalence of severe FOC in Swedish pregnant women? (Study 1, Paper I)

The prevalence of severe FOC for the mixed (both nulliparous and parous women) sample of 1635 pregnant women was $15.6 \%$, while the prevalence of phobic FOC was 5.7\%. The mean level of W-DEQ in the study sample was 62.8 (SD 23.3). Nulliparous women as a group had a higher mean W-DEQ sum score (mean 64.5, SD 21.6) than the group of parous women (mean 60.7, SD 24.9) $(p=0.0009)$. The W-DEQ sum score was normally distributed in the mixed pregnant sample (see Figure 6).

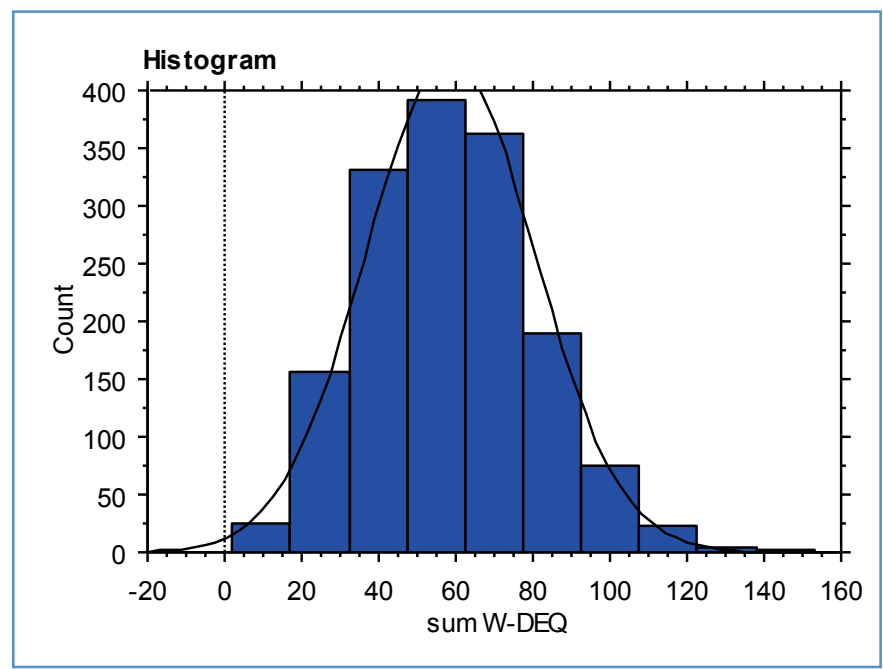

Figure 6. Distribution of the W-DEQ sum scores in the study sample of 1635 nulliparous and parous women in Study 1. 


\subsubsection{Results corresponding to research question 2}

How is severe FOC related to education, maternal age, gestational age, parity and preferred mode of delivery? (Study 1, Paper I)

For parous women, severe FOC and a previous CS correlated strongly $(p<0.0001)$. In nulliparous women, belonging to the age group 30-34 years (i.e. older than the majority) was associated with having severe FOC (OR 2.06 when compared with the reference group of 25-29-yearsold nulliparous women, $p=0.029)$. Education, marital status or gestational age were not associated with severe FOC $(p=0.13-0.95)$, neither for parous nor for nulliparous women.

Women who preferred CS had a higher mean W-DEQ sum score (88.8) than those preferring vaginal delivery (60.6). When compared according to the previous mode of delivery, parous women with a previous CS had a higher mean W-DEQ sum score (76.6), than women with a history of instrumental delivery (65.6) or an uncomplicated vaginal delivery (57.5).

Preferring CS correlated strongly with having severe FOC $(p<0.0001)$ in both parous and nulliparous women. For parous women, even having a history of CS $(p<0.0001)$ or of instrumental delivery $(p=0.045)$ correlated with the preference for CS as mode of delivery.

We found that $9.4 \%$ of parous women and $5.5 \%$ of nulliparous women preferred a CS as the mode of delivery. In the group of 1635 women, $3.1 \%$ of those without a severe FOC (W-DEQ sum score $<85$ ) preferred a CS, slightly more parous women $(4.0 \%)$ than nulliparous women $(2.2 \%)$.

\subsection{Cost of illness of severe FOC (Study 2, Paper II)}

\section{Results corresponding to research question 3}

What is the cost of illness of severe FOC in Swedish women giving birth to their first child? (Study 2, Paper II)

All visits to antenatal- and postpartum health care units as well as delivery clinics, hours on sick leave noted in antenatal records, medication, and hospitalization during pregnancy, delivery and postpartum were 
mapped for the group of women with severe and low FOC respectively, after which the two groups were compared (Table 8). We found a clear difference in health care consumption between the groups. Those with severe FOC had more visits during pregnancy for psychosocial support, and they had more hours on sick leave. Uncomplicated deliveries were more frequent in the group with low FOC. Women with severe FOC stayed longer at the maternity ward and paid more visits postpartum due to complications, both to midwives and obstetricians, than those with low FOC. Women with severe FOC also had more visits due to adverse birth experiences. There was no evidence that the difference in postpartum visits between women with severe and low FOC was related to having/not having had a CS. During pregnancy, only one third of the women with severe FOC (14/43) were identified by the caring system as having troublesome thoughts concerning childbirth and were offered psychosocial support. Table 8 shows in detail the mapped parameters and the differences between the groups.

The societal costs associated with severe FOC were 38\% higher than those associated with low FOC. In Sweden this would generate a yearly extra cost of 13.43 million Euros (SEK 122 million) when following the ordinary obstetric care. Table 9 shows the cost calculations for the group of pregnant women with severe FOC and the group of women with low FOC. 
Table 8. Variables from medical records in the two groups of pregnant women with severe and low FOC in Study 2

$\begin{array}{llll}\text { Severe FOC } & \text { Low FOC } & \text { Statistical } & p \text {-value } \\ \text { W-DEQ } \geq 85 & \text { W-DEQ } \leq 60 & \text { test df (1) } & \\ \mathbf{n}=43 & n=107 & \text { 1) ANCOVA } & \\ \begin{array}{l}\text { Mean (SD) } \\ \text { or } n(\%)\end{array} & \text { Mean (SD) } & { }^{2)} \text { Chi }^{2} & \\ \text { or } n(\%) & & \end{array}$

PREGNANCY VARIABLES

Visits at the Antenatal Care Unit (number of visits)

Visits to midwife, obstetrician,

ultrasound unit, physiotherapist, nutritionist, psychologist

Visit to specialized midwife/counsellor for FOC

$0.72(1.29)$

or n (\%)

Outpatient visit at Maternity Clinic (nr of visits)

Visits to midwife, obstetrician,

telephone consults, days of inpatient care

Medical history (nr of patients)

Lung disease, endocrine disease,

chronic disease (diabetes, heart disease, stroke),

other somatic health problems, psychiatric disease,

previous miscarriage, interruption of pregnancy

\section{Ongoing medication (nr of patients)}

Medication for a somatic problem

Psychotropic medication

$180.9(346.7)$

Hours on sick leave (hours (h))

\section{DELIVERY VARIABLES}

External cephalic version (nr of visits),

inductions ( $\mathrm{nr} /$ patients), bleeding during delivery $(\mathrm{ml})$,

time at delivery ward (h), time from established

contractions to delivery $(\mathrm{h})$

Time at maternity ward $(\mathrm{h})$

Pain relief during delivery ( $\mathrm{nr}$ of patients)

Use of nitric oxygen, epidural anaesthesia

\section{Mode of delivery ( $\mathrm{nr}$ of patients)}

Vaginal delivery with complications,

instrumental delivery, elective cesarean section on

medical indication, emergency cesarean section

Diagnosed as normal spontaneous delivery ${ }^{3}$

Elective cesarean section on maternal request

$\begin{array}{ll}24 & (55.8 \%) \\ 3 & (7.0 \%)\end{array}$

80

$(74.8 \%)$

2) 5.2

2) 7.62

POSTPARTUM VARIABLES (nr of patients*) Outpatient visit to midwife at Maternity Clinic (nr of patients)

Routine

Complication

Psychosocial

Postpartum check-up at the Antenatal Care Unit (nr of patients)

Midwife

Obstetrician

Visit at midwife/counsellor/psychologist postpartum because of negative delivery experience

$\begin{array}{llllll}43 & (100 \%) & 105 & (97.2 \%) & \text { 2) } 3.5 & 0.06 \\ 9 & (20.9 \%) & 8 & (7.5 \%) & \text { 2) } 5.5 & 0.03 \\ 20 & (46.5 \%) & 15 & (14.0 \%) & \text { 2) } 18.1 & 0.001\end{array}$

\section{FOC=fear of childbirth.}

* Number of patients reported instead of number of visits, as the distinct visits per woman were few, often none.

1) Ancova with age as covariant; ${ }^{2)} \mathrm{Chi}^{2} ;{ }^{3}$ ) diagnosis according to ICD-10. 


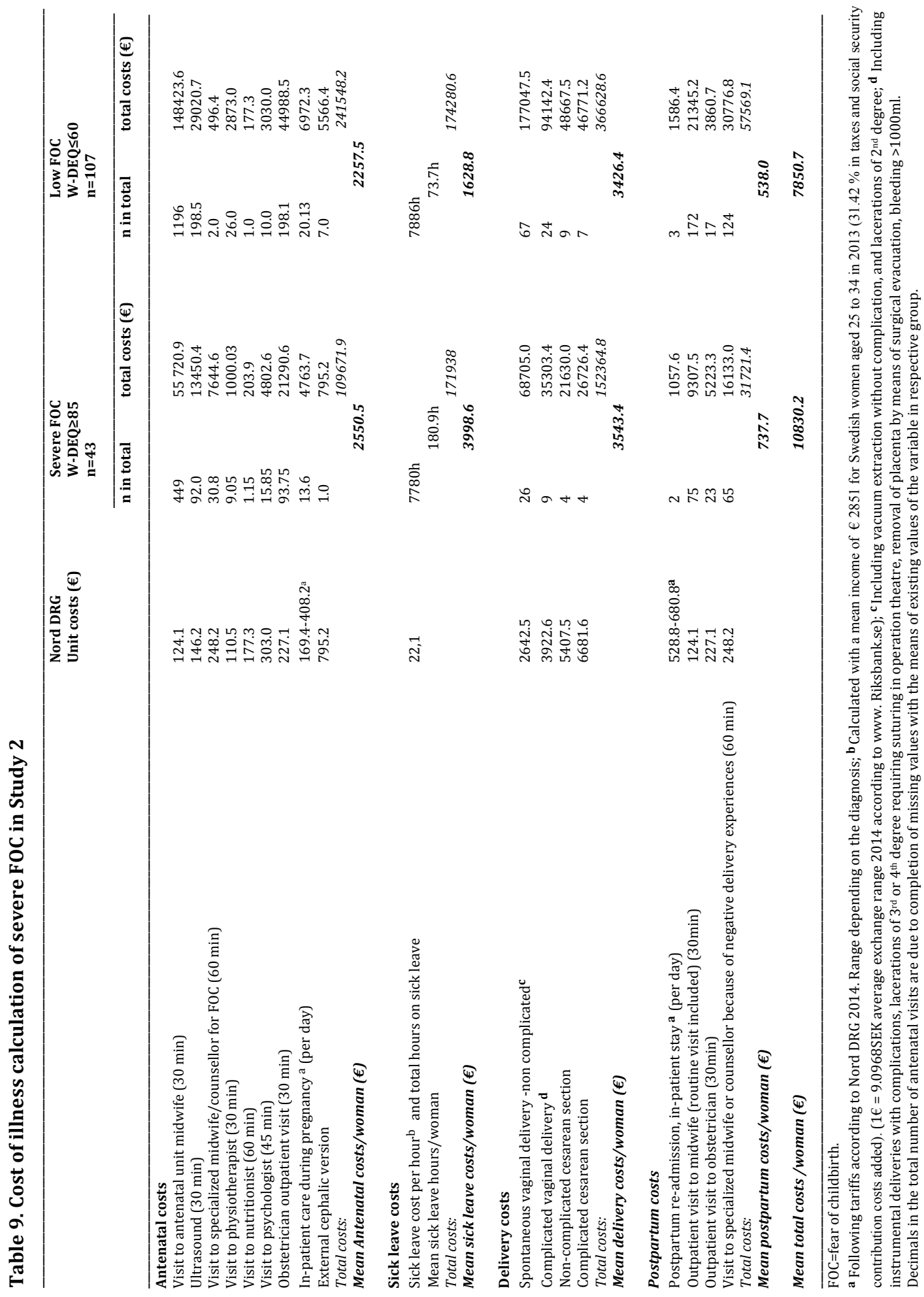




\subsection{Treatment of nulliparous women with severe FOC over the Internet (Study 3 and 4, Paper III and IV)}

\section{Results corresponding to research question 4}

What is the feasibility of an Internet-based therapist-supported self-help program based on cognitive behaviour therapy to treat severe FOC in nulliparous pregnant women? (Study 3, Paper III)

At inclusion, the participants $(\mathrm{n}=28)$ had a mean W-DEQ sum score of 125 (min-max 90-159). The majority (86\%) had a phobic FOC (W-DEQ sum score $\geq 100$ ). The mean age of the participants was 30.5 years and the majority had a university degree and were cohabitant.

Fifteen women completed all the eight weeks of therapy. We found that $75 \%$ of the participants $(21 / 28)$ followed at least five modules $(63 \%$ of the program). Of the women who did not complete the therapy $(n=13)$ three gave birth prior to completion, three announced their discontinuation and seven did not respond to the appeals to continue.

By means of the data collected at inclusion, women who had completed all the eight weeks of ICBT $(n=15)$ could be compared with those later discontinuing $(n=13)$. No statistically significant differences appeared in the number of participants with severe anxiety $(p=0.8)$ or depression $(p=1.0)$ as measured with the HADS. The discontinuing group had a mean W-DEQ A 130.5 (min-max 108-159) at inclusion.

When the effect of the therapy was counted for the group of all participants, from pre- to post-treatment (as the last reported result carried forward) the effect size of the treatment was large (Cohen's $d=0.95$ ). The mean last reported W-DEQ A sum score for all the participants was 95 (min-max 34-158).

At the follow up, three months postpartum, 24 women could be contacted for a telephone interview. Their mean W-DEQ B score was then 53 (min-max 8-138, SD 26.6). Two of the participants described an adverse experience of the delivery. One had a vaginal delivery and the other a trial of vacuum extraction, which ended with an urgent CS. The first woman had a blood phobia in addition to her severe FOC and the other 
woman had a history of sexual abuse. At follow up, $86 \%$ ( 24 of the 28 women that could be contacted) reported that they had had a vaginal delivery, two a vacuum extraction, three an elective caesarean section, and one an urgent caesarean section. Four women could not be contacted (women who actively declined to continue were excluded $n=3$ and one could not be reached).

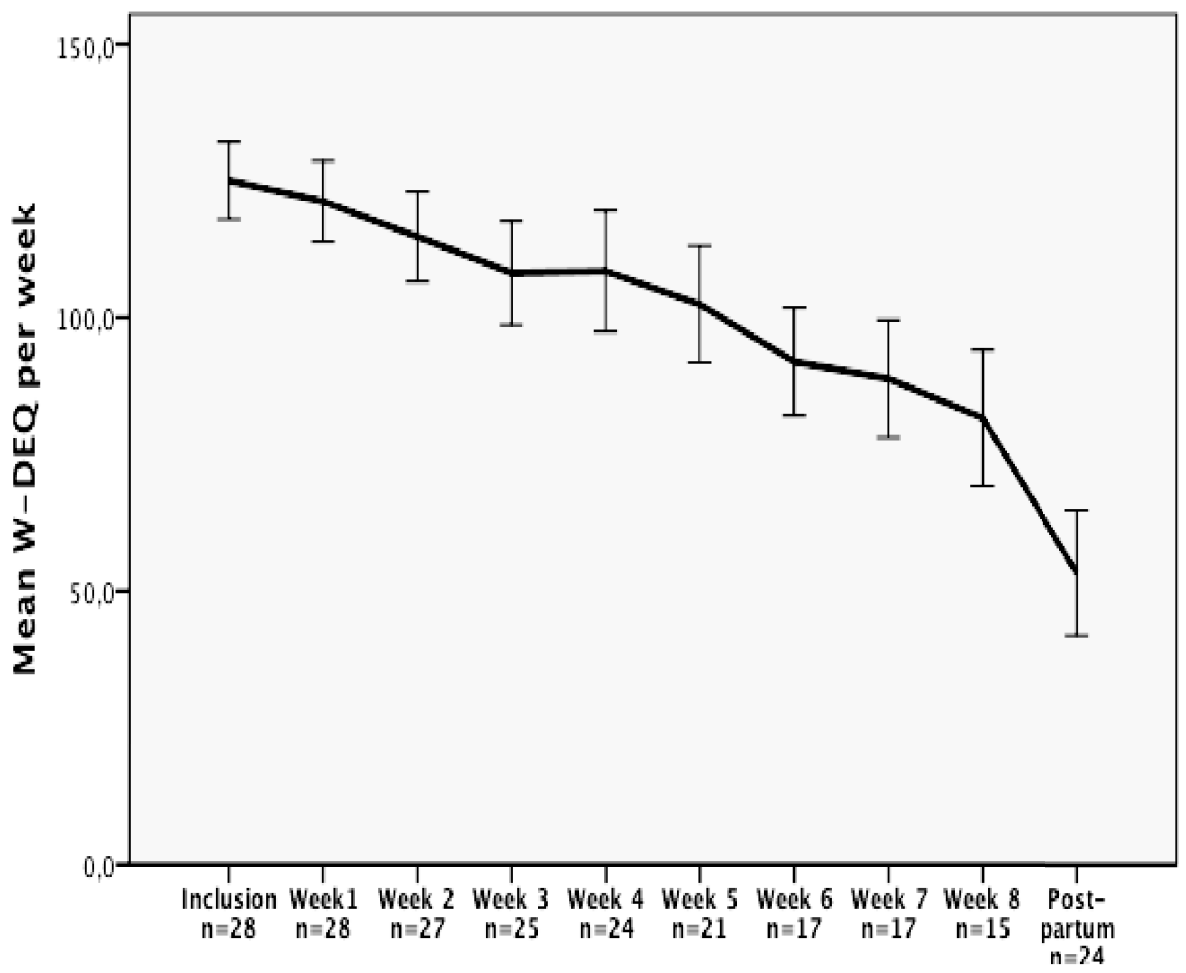

Figure 7. The mean W-DEQ sum scores week by week during the treatment with ICBT in a group of nulliparous women with severe fear of childbirth in Study 3. W-DEQ A sum scores during pregnancy, W-DEQ B sum score postpartum. Participants worked with the modules between the weekly W-DEQ measures.

The results for the 15 participants, completing the whole program, were also studied separately. In this group, the mean W-DEQ A sum score after treatment was 81.6 (min-max 31-122). When the weekly measures of the level of FOC were analysed with ANOVA (the degree of freedom was corrected using Greenhouse-Geisser estimates of sphericity) the 
results showed a statistically significant decrease of FOC during treatment $(\mathrm{F}(3.4,48.2)=27.35, p<0.0001)$. The Bonferroni post hoc correction revealed that the decrease started after module three, which introduced the exposure tasks (the difference in W-DEQ A sum score from pre-treatment to module four $16.6+/-6.4, p=0.02)$. At the posttreatment measure, $53 \%$ of the participants (eight women) no longer had severe FOC (W-DEQ B sum scores 31-78), 27\% (four women) had reduced their FOC from phobic to severe FOC (W-DEQ A sum scores 9499), and 20\% (three women) had still phobic FOC (W-DEQ A sum scores 100-120), but had decreased their W-DEQ A sum scores by 1922 points.

In the follow up telephone interview the participants were asked about their experiences of working with the program. They reported that they highly appreciated the brief feedback received from their Internettherapist and the possibility to work with the program when it was most convenient for themselves, without the need to make an appointment or to travel to a clinic. Yet one woman had preferred a weekly live therapy visit. Even though in the introduction participants had been advised to allocate at least two to three hours per week for working with the program, many were surprised about the time needed to complete the homework. The majority $(86 \%, 24 / 28)$ of the participants could be contacted at the three-months postpartum follow up. They reported that the program had been helpful during pregnancy and labour. One woman found it frightening to read about the delivery, and therefore did not find the program useful. She said that participation in half of the program made her realize that she needed help, which prompted her to tell her midwife at the antenatal clinic about her FOC.

The participants had the opportunity to contact their therapist whenever they wanted. Nevertheless, there were only a few contacts beyond the weekly correspondence concerning the homework.

The therapists used 5-22 minutes for one session (mean 12 minutes), per patient and week. For the therapists the secure contact system became a virtual therapy room, and the contact with the patients resembled a traditional therapist relationship, but based on text. 


\section{Results corresponding to research question 5}

How do nulliparous pregnant women with severe FOC describe their expectations of the imminent delivery before and after treatment with Internet-based cognitive behaviour therapy (ICBT)? (Study 4, Paper IV)

The 15 pregnant nulliparous women who completed all eight weeks of the ICBT program for treatment of severe FOC (Study 3, Paper III), were included as informants in this qualitative study. Their short narratives were based on the tasks presented in Table 4 and dealt with their expectations of the imminent delivery before treatment. These narratives were analysed with thematic analysis to find domains and themes common in the texts. The same analysis was carried out on the narratives similarly retrieved after therapy had been completed. When preand post-treatment narratives were compared, three domains of change could be identified; the participant's own role, the role of the others, and the attitude towards the baby. In these domains six common themes of change from pre- to post-treatment could be observed: fear, selfconfidence, coping, my partner, the staff, my baby.

Prior to therapy, the 15 informants described chaos in their expectations of pain and panic. They felt alone despite their partners or the staff being present in the labour room. They described a poor self-confidence and often used avoidance as a coping strategy. They regarded their partners as uncertain or lost in the unfamiliar situation of the delivery ward and did not think they could be helpful. Many informants imagined the staff to be people who were distant and who did not listen or were not available to help them. The majority of informants did not mention thinking of the baby at all during labour, until they were asked to describe the first moment when they would be with the baby. When the baby was mentioned prior to therapy, it was in relation to concern about serious incidents.

After therapy, the informants described a more realistic attitude (based on facts) towards their imminent childbirth; they could still have doubts as they were going to face a new challenge, but they were more selfconfident and described how they would use more active coping strategies. They perceived their partners as more active, competent and supportive, while the staff was expected to be more helpful and to be pre- 
sent when needed. They were also more aware of the approaching meeting with their baby all through labour and delivery. They described thoughts of the baby, which could help them to cope with the long course of labour. Table 10 shows the domains and themes pre- and posttreatment.

Table 10. Main domains with themes prior to and after an eight-week ICBT programme via the Internet in a nulliparous group of women with severe fear of childbirth in Study 4

\begin{tabular}{lll}
$\begin{array}{l}\text { Main domains } \\
\text { and themes }\end{array}$ & Before treatment & After treatment \\
\hline
\end{tabular}

My own role

$\begin{array}{lll}\text { Fear } & \begin{array}{l}\text { Anxiety, uncertainty, } \\ \text { loneliness, hopelessness }\end{array} & \begin{array}{l}\text { Doubt and hope } \\ \text { simultaneously }\end{array} \\ \text { Self-confidence } & \text { Lacking self-confidence } & \text { Myself as an active subject } \\ \text { Coping } & \begin{array}{l}\text { Avoidance as coping } \\ \text { strategy }\end{array} & \text { Active coping with labour }\end{array}$

The role of others

$\begin{array}{lll}\text { My partner } & \begin{array}{l}\text { My partner as } \\ \text { uncertain/lost }\end{array} & \begin{array}{l}\text { My partner as an } \\ \text { active supportive person }\end{array} \\ \text { Staff } & \begin{array}{l}\text { The staff is not listening to } \\ \text { helping me }\end{array} & \begin{array}{l}\text { The staff is present, and } \\ \text { supporting, available }\end{array}\end{array}$

Attitude towards my baby

\begin{tabular}{|c|c|c|}
\hline My baby & $\begin{array}{l}\text { Focus on the baby only } \\
\text { after the delivery }\end{array}$ & $\begin{array}{l}\text { Focus on the baby } \\
\text { throughout labour and } \\
\text { delivery }\end{array}$ \\
\hline
\end{tabular}




\subsection{Treatment of childbirth-related PTSD symptoms over the Internet (Study 5, Paper V)}

\section{Results corresponding to research question 6}

Is Internet-based cognitive behaviour therapy feasible for treating women with posttraumatic stress symptoms following childbirth? If so, what is the effect of the therapy? (Study 5, Paper V)

All participants $(\mathrm{n}=56)$ in this RCT of Internet-based trauma-focused cognitive behaviour therapy for the treatment of childbirth-related posttraumatic stress symptoms reported a previous delivery as the traumatic event, and had PTSD symptoms of important magnitude, as measured both with the TES and the IES-R. At inclusion, 46.4\% of the participants met all criteria for PTSD as measured with the TES (Table 11), and $25 \%$ when assessed with the MINI interview (Table 12).

The comorbidity was assessed with the clinical MINI interview and showed that $68 \%$ of all participants $(n=56)$ had a present psychiatric disorder, and $80.3 \%$ had a lifetime experience of suffering from psychiatric disorders. At inclusion the most frequent comorbidity disorders were major depressive disorder (MDD) (54\%), social phobia (18\%) and generalized anxiety disorder (GAD) (11\%). After their treatment, 33.3\% of the women in the index group still met all the criteria of PTSD as measured with the TES, and $66.7 \%$ suffered from PTSD symptoms (Table 11). In the index group, after their treatment, when the clinical relevance of the treatment for the comorbidity was assessed with the MINI interview, 22\% (vs. 64\% pre-treatment) had an on-going psychiatric diagnosis; $11 \%$ (vs. $54 \%$ pre-treatment) had MDD, 5.6\% (vs. 22\% pre-treatment) had social phobia and $5.6 \%$ (vs. $11 \%$ pre-treatment) had GAD. For more details of comorbidity see Table 13 . 


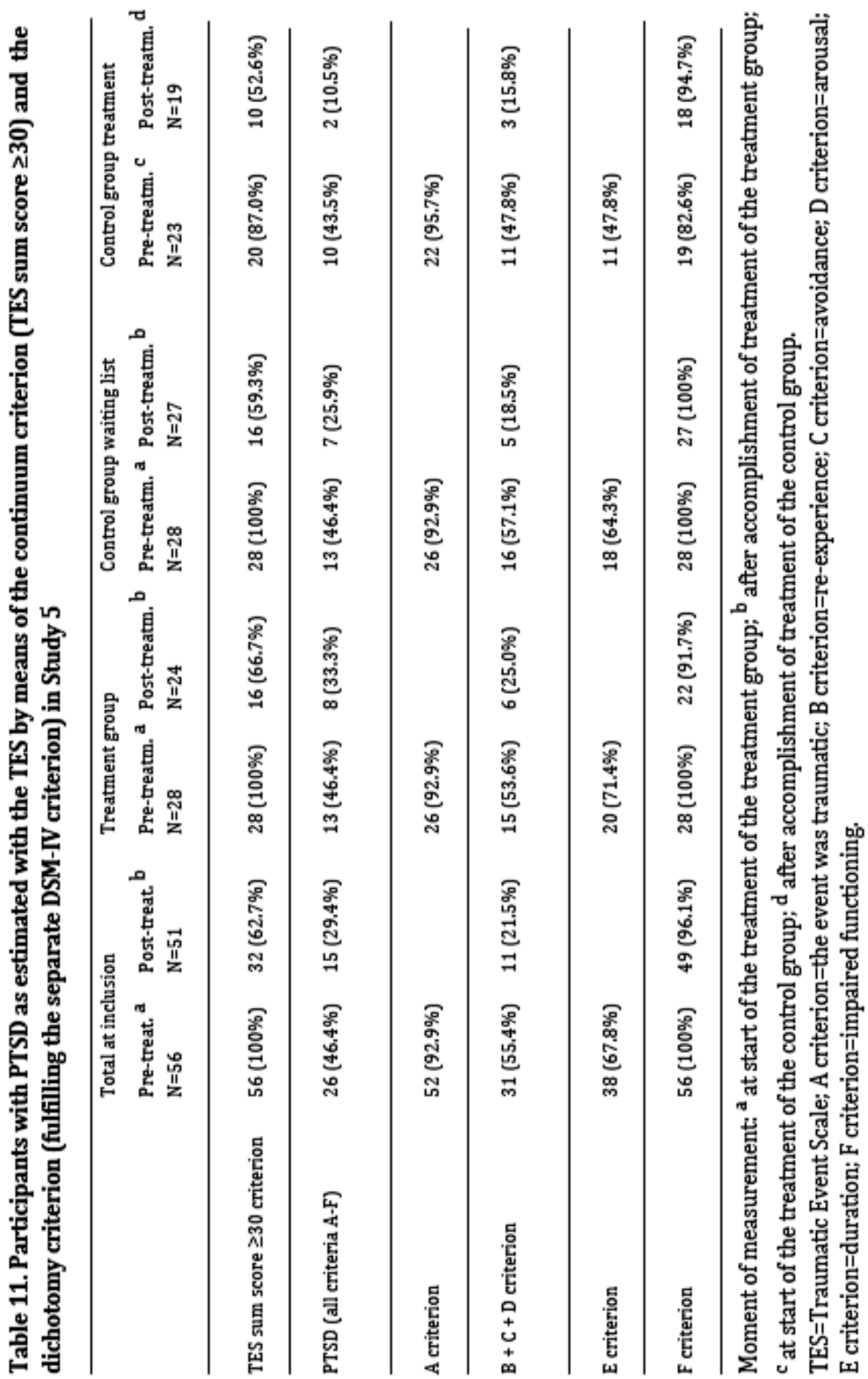


Results

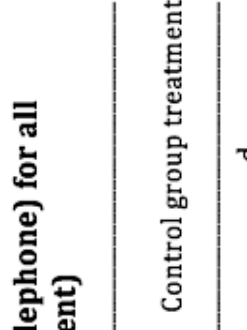

|

$\Phi$

웡

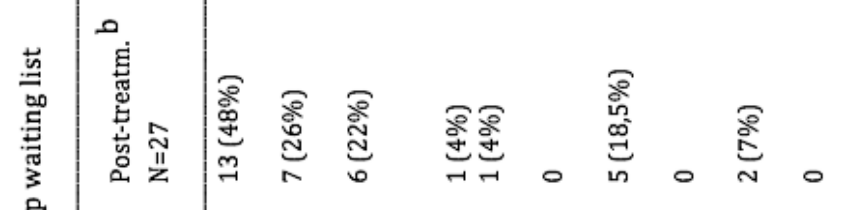

竞莣

효

"⿹

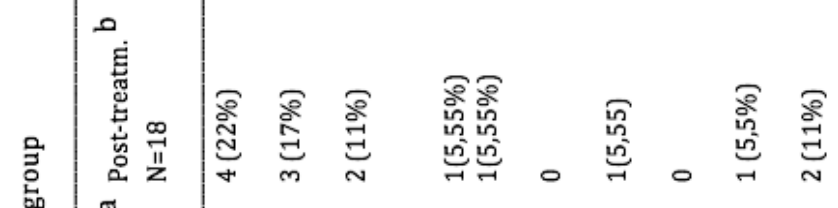

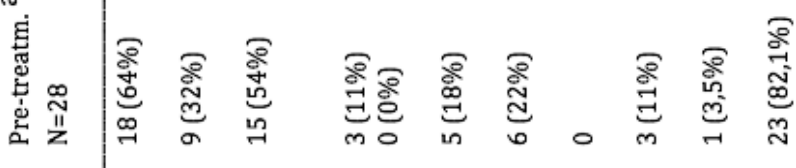
مـ.

离 范

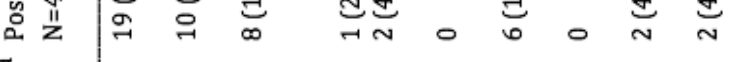

焉

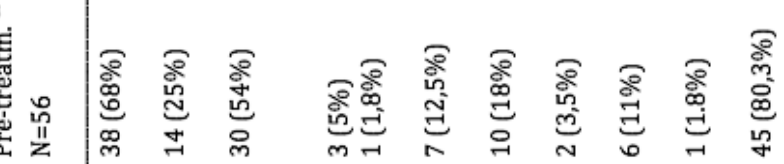




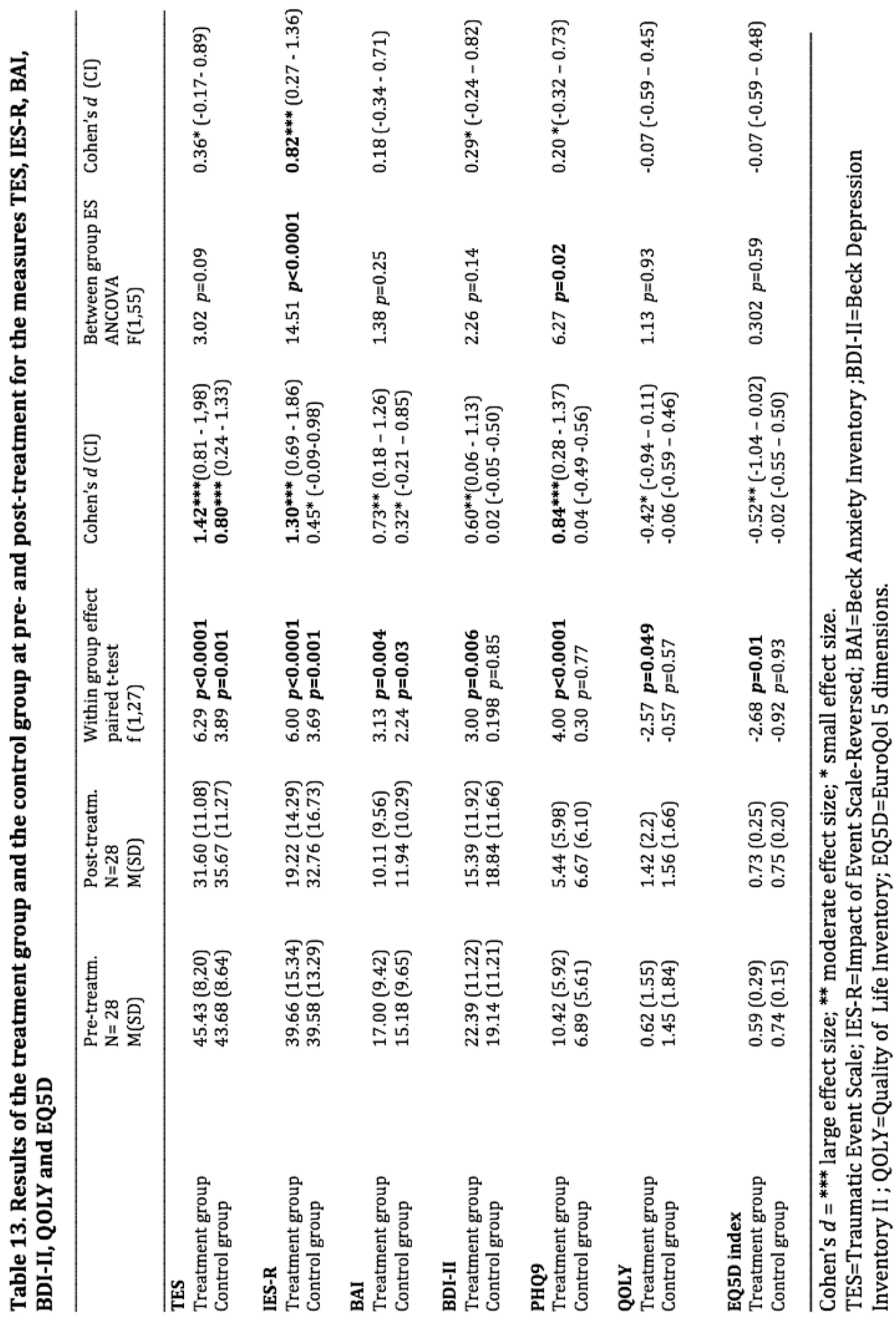


When comparing the index group after their treatment with the control group after their waiting list period, for the main outcome measure PTSD symptoms, there was a large between-group effect size (ES) as measured with IES-R $(d=0.82, p<0.0001)$ and a small ES, when measured with TES $(d=0.36, p=0.09)$. In this comparison, for the secondary outcome measure of depression, there was a small ES measured with PHQ-9 $(d=0.2, p=0.02)$ but not for BDI-II $(d=0.29, p=0.14)$. The other secondary outcome measures did not show any between-group ES.

For the index group, the within group ESs were large for PTSD symptoms (measured with both TES $d=1.42$ and IES-R $d=1.30, p<0.0001$ ) and for depression (measured with PHQ-9 $d=0.84, p>0.0001$ ). The within group ESs were moderate for anxiety (measured with BAI $d=$ $0.73, p=0.004$ ) and for depression (measured with BDI-II $d=0.60$, $p=0.006$ ). The within group ES for quality of life was moderate when measured with EQ5D $(d=0.52, p=0.001)$ and small measured with QOLI $(d=0.42, p=0.049)$.

During the treatment period of the index group, the control group was in a waiting list condition, but received weekly measures with the TES and the PHQ-9. For the control group, during this period, it appeared that there was a large within group ES for PTSD symptoms according to the TES $(d=0.8, p=0.001)$, and a small ES for PTSD symptoms according to the IES-R $(d=0.45, p=0.001)$, and for anxiety symptoms on the BAI $(d=0.32, p=0.03)$. The detailed results of the treatment (index) and control groups are shown in Table 13.

When the control group had received its deferred treatment, a large within-group ES appeared from inclusion to post-treatment for the main outcome measures of PTSD symptoms (TES $d=0.9, p=0.003$; IES-R $d=1.33, p=0.0001)$. For the secondary outcome measures there was a small ES for depression (BDI-II, $d=0.44, p=0.05$ ), a moderate effect size for anxiety (BAI, $d=0.75, p=0.005$ ), and a large ES for quality of life (measured with EQ5D $d=-1.65, p<0.0001$ ). The detailed results of the control group are shown in Table 14. 


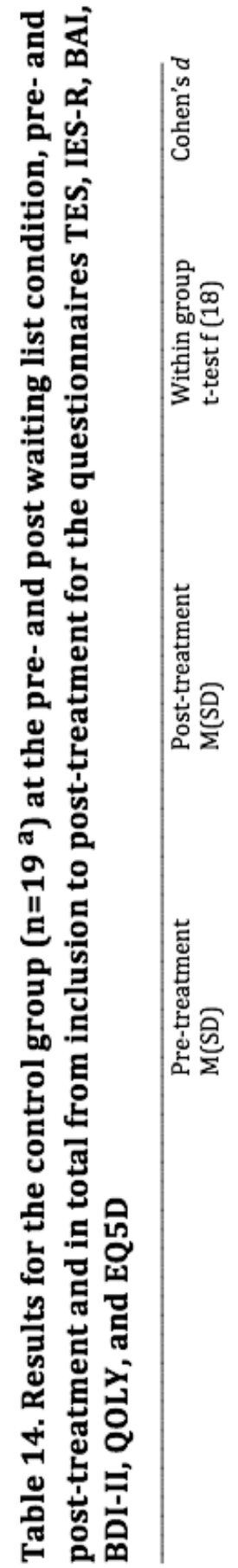

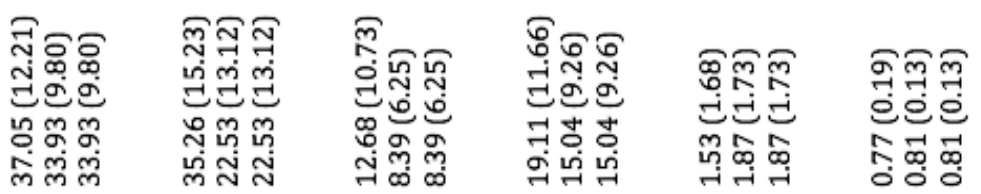

ㅈํำ ำ

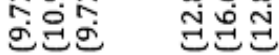

舟웅

견워

응요

बंत

ले ल

离

淢节

焉

옵.

官言言

造战

궁이

解言言言

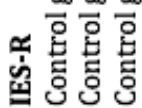
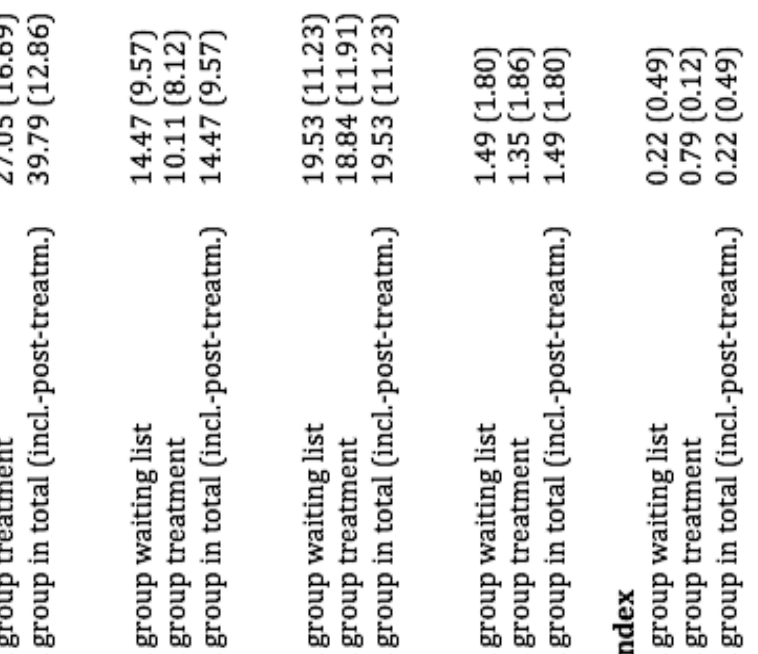

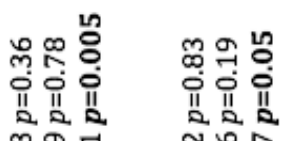

ตำ

ㄱํํ융

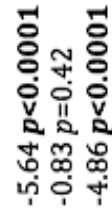


In the index group 54\% (13/24) completed all eight weeks of treatment and $67 \%(16 / 24)$ accomplished at least four modules. In the control group, 26\% (5/19) completed all eight weeks of treatment, and $61 \%$ (11/18) finished at least four modules during the eight weeks treatment period. In the index group participants completed on average 5.8 modules $(72.5 \%$ of the treatment) whereas the control group completed on average 4.7 modules ( $59 \%$ of the treatment). The index group reported an average time of 3.4 hours (min-max 0.6-7 hours, median 3 hours) spent on working with their homework, whereas in the control group, the participants reported 5.4 hours per week (min-max 1-10 hours, median 4 hours).

Participants who had not participated in all modules but had completed the follow up questionnaire, gained access to the missing modules, and thus had the opportunity to complete the program on their own.

Almost all the participants (92.3\%) found the modules easy to read and understand, but for the majority it was demanding to work with their trauma. There were many participants in the control group who regretted having agreed to wait for the treatment. They described that the long waiting time had minimized their hope and the motivation they had felt at inclusion. Many of them had difficulty completing one module per week, as they felt so bad. Several would have preferred more time to complete the therapy, or the possibility to follow an individual schedule. Regardless of all the difficulties, the majority in both groups found the therapy helpful for their problems $(83.3 \%$ in the index group and $82.4 \%$ in the control group) when asked at the post-treatment follow up. 


\section{GENERAL DISCUSSION}

\subsection{Discussion of the main findings}

\subsubsection{Prevalence of severe FOC and variables related to severe FOC and preference for CS (Study 1, Paper I)}

\section{Research questions 1-2}

What is the prevalence of severe FOC in Swedish pregnant women? How is severe FOC related to education, maternal age, gestational age, parity and preferred mode of delivery? (Study 1, Paper I)

The prevalence of $15.6 \%$ of severe FOC (measured with the W-DEQ) in our mixed Swedish sample from 2006 (among parous women 16.5\% and among nulliparous women 14.8\%) was at time of Study 1 higher than in previous comparable studies (9.1-11\%) (Ryding et al. 1998; Zar, Wijma \& Wijma 2002; Spice, Jones, Hadjistavropoulos, Kowalyk \& Stewart 2009). In a recent study, Lucasse, Schei \& Ryding (2014) found in a Swedish sample a similar prevalence of severe FOC $(14.9 \%$ in a mixed sample; $14.6 \%$ for nulliparous and 15.2 for parous pregnant women). The prevalence of phobic FOC in our study (5.7\%) was at that time double the number seen previously (2.7\%) (Zar, Wijma \& Wijma 2002) but lower than in more recent Finnish studies with nulliparous pregnant women (7.0-8.1\%) (Rouhe et al. 2009; 2013).

The mean level of the W-DEQ A sum score in our mixed Swedish pregnant sample was 62.8 (SD 23.3) (for nulliparous 64.5 (SD 21.6.) and for parous 60.7 (SD 24.9). Similar levels have been seen in a mixed Finnish (mean W-DEQ A sum score 68.3) and in a nulliparous Swedish sample (mean W-DEQ A sum score 68.5) (Rouhe et al. 2009; Salomonsson, Gullberg, Alehagen \& Wijma 2013). Studies in other Western countries have reported lower mean W-DEQ A sum scores in mixed samples (mean W-DEQ A sum score 49.5-57.0) (Toohill, Fenwick, Gamble \& Greedy 2014a; Lucasse, Schei \& Ryding 2014). 
In accordance with what previous studies (Zar, Wijma \& Wijma 2001; Rouhe et al. 2009) have shown, we found that FOC was normally distributed in the pregnant sample.

Our results support the findings that severe FOC is associated with a previous CS and instrumental delivery in parous women (Ryding et al. 1998; Rouhe et al. 2009; Nilsson et al. 2012; Lucasse, Schei, Ryding 2014; Söderqvist, Wijma \& Wijma 2002), and with elevated maternal age in nulliparous women (Räisänen et al. 2014). We did not find any correlation between gestational age, social support (measured as marital status in our study) or educational level, as has been suggested by others (Saisto et al. 2001; Laursen, Hedegaard \& Johansen 2008; Lucasse, Schei, Ryding 2014).

Preceding studies (Söderquist, Wijma \& Wijma 2006; Ayers et al. 2016) have shown, that severe FOC is one of the most important predictors for postpartum PTSD symptoms. In our study, severe FOC was associated with a history of CS and instrumental delivery, which could indicate, that these women had experienced their delivery as traumatic. This could therefore explain why the prevalence of severe FOC was higher in the group of parous women than in the group of nulliparous women, in accordance with Swedish and Finnish studies. In material from Australia, and other European countries (Toohill et al. 2014a; Lucasse, Schei \& Ryding 2014) parous women as a group do not have higher FOC than nulliparous women, which may reflect the different countries legislations and traditions, where the pregnant woman can decide for herself about the mode of delivery, and thus does not need to face the feared situation again if she is anxious.

The discussions in Nordic countries about CS on maternal request have raised the question of whether there are women without severe FOC preferring a CS as the mode of delivery. Our results showed that this applied to only a fraction (3.1\%) of all pregnant women $(2.2 \%$ of nulliparous and $4.0 \%$ of parous). This is supported by the strong correlation between a severe FOC and a request for CS as seen in our results $(p<0.0001)$, and is in line with the results in previous studies conducted both in Sweden (Wiklund, Edman, \& Andolf 2007; Salomonsson et al. 2013) and in a multi-centre study conducted in five European countries (Ryding et al. 2015). 


\subsubsection{Cost of illness of severe FOC (Study 2, Paper II)}

\section{Research question 3}

What is the cost of illness of severe FOC in Swedish women giving birth to their first child? (Study 2, Paper II)

The health-economic aspects of severe FOC have been little studied. A recent study from United Kingdom conducted by Bauer, Knapp and Parsonage (2016) calculated the combined societal lifetime cost of perinatal anxiety and depression as $£ 8500$ (SEK 102000 or $€ 11213$, when counted $£ 1=$ SEK $12=€ 9.0968$ ) per woman giving birth/year. For women with peripartum depression, the lifetime cost was calculated as $£$ 75728 and for peripartum anxiety as £ 34811. Most of the incremental costs $(60 \%)$ were related to negative impact on children (Bauer, Knapp $\&$ Parsonage 2016). Perinatal anxiety and depression cover broader aspects than FOC only, but give an indication that mental illness during this life period is associated with major economic consequences for the society. In our cost of illness comparison of women attending care as usual during pregnancy, delivery, and postpartum we could see that severe FOC was associated with $38 \%$ additional costs to the society for women with severe FOC compared with those with low FOC. Our study design did not include the eventual additional costs of a negative impact of the FOC on the baby, which probably would have increased the difference.

There is a high comorbidity between FOC and other psychological problems. Therefore, it is not possible to state that all the costs we have seen are due to FOC solely, but FOC could be seen as an indicator of psychological vulnerability that influences societal costs during this period.

Not all women with severe FOC are identified during pregnancy, but a demand for a CS might indicate that severe FOC is present. In our sample, one third of the women with severe FOC were referred to supportive counselling. As there are seldom any systematic ways of screening for FOC, many nulliparous women will not be discovered in time and will continue to use avoidance as their coping strategy for handling FOC, as long as they manage to deny the progressing pregnancy. 
Pregnant women in Sweden have great trust in their obstetrically wellfunctioning antenatal care provider (National Board of Health and Welfare 2015). Most antenatal clinics have limited capacity to offer therapeutic counselling to the extent that a woman with severe or phobic FOC will need. The interventions used in obstetric care may often help the women with severe FOC to manage the delivery itself, but do not influence the women's anxiety, or psychological trauma. This was also seen in a study evaluating the effect of interventions in the ordinary obstetric care, suggesting that more effective methods are needed (Larsson et al. 2015).

Psychological problems should be addressed with psychological methods in order to help the women, not only through the pregnancy, labour and delivery, but also in order to facilitate the start of the woman's parenthood and a close relationship to the child. There have been promising results of interventions to address severe FOC (Rouhe et al. 2013; 2015a; 2015b). According to our study, in Sweden the additional societal cost of severe FOC managed in the conventional obstetrical care is around 13.43 million Euros. This considerable sum raises the question of whether the Swedish society really can afford not to offer adequate therapy to women with severe FOC.

\subsubsection{Treatment of nulliparous women with severe FOC over the Internet (Papers III-IV)}

\section{Research question 4}

What is the feasibility of an Internet-based therapist-supported self-help program based on cognitive behaviour therapy to treat severe FOC in nulliparous pregnant women? (Study 3, Paper III)

Due to the strong evidence for the effectiveness of cognitive behavior therapy (CBT) in the treatment of anxiety disorders (Barlow 2004 pp. 408-418; Foa, Frances \& Davidson 1999; Rosqvist 2012) we developed our treatment protocol in accordance with standard CBT methods. As ICBT is widely studied in the treatment of various psychological problems, especially of anxiety disorders, and shows high effectiveness (Andersson 2009; Cuijpers Van Straten \& Andersson 2008a; Cuijpers et 
al. 2008b; Hedman, Ljóttson \& Lindefors 2012), we wanted to test this new way of providing therapy in the context of childbirth anxiety.

Our results show that ICBT can be used for childbirth anxiety, and that it is well accepted by the participants and therapists. ICBT is particularly suitable for persons with obstacles to treatment, such as difficulties to getting access to treatment because of geographical distance or lack of therapists, difficulties with office-hour appointments, lack of money or fear of being stigmatized.

Following the program was associated to a clear decrease in the level of FOC in the participants, when compared from pre- and post-treatment (mean 30 points on the W-DEQ sum score) and further postpartum (mean decrease by 72 points on the W-DEQ sum score). There was a large with-in group effect size of the treatment before delivery (Cohen's $d=0.95$ ). Postpartum the level of FOC decreased additionally, and showed levels comparable with the normal Swedish sample postpartum. In the group following the entire eight weeks program the level of FOC (measured with the W-DEQ A) was reduced for all participants.

At inclusion, the majority of participants had higher levels of FOC (mean W-DEQ sum score 125; SD 18.2) than we expected (a mean WDEQ sum score 95). This was surprising as we assumed that women with very high levels of FOC would avoid searching for information or help. Probably, the design had attracted pregnant women who coped with their FOC by processing, i.e. by obtaining all available information (Eriksson, Westman \& Hamberg 2005). This might have biased the recruitment, attracting more motivated participants.

Our modules were built on anxiety theories and followed evidence based CBT methods for treatment of anxiety disorders. It was shown to be important to assess the women's comorbidity, as two of the participants, after decreased levels of FOC pre-partum, had again high FOC postpartum. By retroactive inspection, the pre-treatment interview showed that one had a history of sexual abuse and the other, in addition to her severe FOC, had also blood and injection phobia. Neither of these two problems was addressed specifically in the standardized therapy. 
In a clinical sense, the most optimal effect of a treatment should be to achieve a level of FOC comparable to normal population. This happened for more than half $(53 \%, n=8)$ of the completers of all eight weeks of treatment. But even reducing fear from very high levels of FOC gives the woman a considerable alleviation of the suffering in her everyday life. The women with only slightly reduced but still very high (phobic) FOC, could quantitatively be seen as non-responders. Nevertheless, when their descriptions of the imminent delivery were analysed (see section below Study 4, Paper IV), although still describing serious doubts when facing the unknown imminent delivery, they now could handle the uncertainty in a more realistic way compared to their description of the event before treatment. Given that our sample was small the results needs to be further studied in larger trials, even studying the long-term effects. Therefore this study is followed by an on-going trial comparing ICBT with traditional, therapist-lead therapy.

\section{Research question 5}

How do nulliparous women with severe FOC describe their expectations of the imminent delivery before and after treatment with Internetbased cognitive behaviour therapy (ICBT)? (Study 4, Paper IV)

For a woman expecting her first child, the imminent delivery is an unknown situation she has not faced before, and is experienced by many even as unavoidable and uncontrollable (Wijma 2003). Without any previous personal experiences to rely on, this may create doubts about one's capability of coping with the unknown. High prenatal anxiety has been related to lower confidence in one's own ability to cope with labour and delivery (Beebe, Lee, Carrieri-Kohlman \& Humphreys 2007). This was seen also in the short pre-treatment narratives in our study, when the informants described the given situations as chaotic and dominated by their fear.

According to Bandura (1977), a treatment of choice for severe FOC should be to work through distressing elements about childbirth and encourage positive anticipations of the same. In order to prevent a negative childbirth experience the treatment should also include the elements of affirming that negative events can be managed. The aim of the ICBT program in our study was to reduce anxiety, but also to strengthen the 
individual's ability to cope with the unknown. This seems to have given the participants a more realistic attitude towards their own ability, and a more realistic attitude to the child, the partner and the staff, all of which helped them during labour and delivery. The ICBT program could be presumed to have promoted the participant's self-efficacy beliefs during pregnancy. Unfortunately we did not measure this during the program.

\subsubsection{Treatment of childbirth related PTSD symptoms over the Internet (Study 5, Paper V)}

\section{Research question 6}

Is Internet-based cognitive behaviour therapy feasible for treating women with posttraumatic stress symptoms following childbirth? If so, what is the effect of the therapy? (Study 5, Paper V)

Women with childbirth-related PTSD seldom receive adequate treatment as their contact with their maternity clinic has often ended when their problems become manifest, and they have not been identified by the primary service as suffering from childbirth-related PTSD (McKenzie-McHarg et al. 2015). This was seen in our study, as the majority of the applicants had not been identified in this way by ordinary maternity and primary care services. Because there are no previous reports on ICBT, we wanted to study the feasibility of Internet-based treatment in this group. We developed and tested a trauma-focused ICBT program focusing on childbirth as the traumatic event. The modules were built on evidence-based principles from trauma- focused CBT therapies (Foa, Frances \& Davidson 1999; Robjant \& Fazel 2010) and inspired and partly derived from previous ICBT projects for treatment of PTSD (Ivarsson et al. 2014).

Our results show that trauma-focused ICBT is feasible in the treatment of women who have experienced birth giving as a traumatic event, and it seems to be effective in decreasing childbirth-related PTSD symptoms. The effect was clear in the index group receiving treatment immediately after inclusion. There was also a decrease of PTSD symptoms in the control group, already during the waiting list period. This was probably the reason why the between-group ESs were small. When it 
was their turn, the control group showed more modest treatment effects than the treatment group.

The decrease of PTSD symptoms in the control group during their waiting list period surprised us, but could probably be explained by the fact that they had been promised to receive the same therapy afterwards (socalled exaggerated expectation). The decrease in the PTSD symptoms may also partly be due to the weekly reminder of their traumatic experience by the delivery-specific items in the TES, probably also explaining why the ES for the TES (as a delivery-specific measure) was larger than for IES-R (not developed for delivery-related problems specifically) in connection to the waiting list period.

After their respective therapy, symptoms of depression measured with BDI-II decreased in the index group (within-group ES $d=0.6, p=0.006$ ) but not in the control group $(d=0.36, p=0.19)$; the between-group ES (index vs control group) was not statistically significant $(d=0.29$, $p=0.14$ ). It is possible that the follow up time in general for the groups was too short to see clear effects on depression. After treatment, in both groups, the MINI interview showed a decrease in the number of women with MDD according to DSM-IV (54\% for the index group pretreatment to $11 \%$ post-treatment, and for the control group from $54 \%$ pre-treatment to $5 \%$ post-treatment). Anxiety symptoms measured with BAI decreased in both the index group $(d=0.73, p=0.004)$ and in the control group $(d=0.32, p=0.03)$, but the ES did not differ between the groups in any significant way after treatment of the index group and waiting list period of the control group $(d=0.18, p=0.25)$. However, according to the MINI clinical interview, there were fewer women with anxiety related disorders after the treatment in the index group (pretreatment $62 \%$ vs. post-treatment $22 \%$ ) compared with the control group (pre-treatment $42.9 \%$ vs. post-waiting list $33 \%$ ). The quality of life was increased in the index group from pre- to post-treatment (EQ5D; $d=0.52, p=0.01$ and QOLY $d=0.42, p=0.049$ ).

When the control group received their treatment, they also had the positive within-group effects of the treatment, though more modest than in the treatment group after their treatment. We presume that the waiting list period, with the weekly repeated "pseudo-exposure to traumatic memories" by means of the TES items (without any help for assimila- 
tion), might have strengthened their pre-existing coping strategies, which made the deferred therapy more difficult to manage during the fixed eight weeks of program. This could also explain why there were $54 \%$ in the index group and only $28 \%$ in the control group who completed all eight weeks of treatment. The same trend was seen when participants in the index group completed on average $73 \%$ of the treatment, and in the control group on average $59 \%$ of the same during the given time. At the follow up, after their respective treatment, the majority in both groups found the program helpful for their problems $(83 \%$ for both groups).

In accordance with previous studies, we found that treating PTSD influences the comorbidity in an ameliorative way (Bradley, Schwartz \& Kaslow 2005). The clinical relevance of the treatment, evaluated as presence of any DSM-IV diagnosis (MINI interview), showed half as many diagnoses in the index group after treatment as in the control group while still on the waiting list. After the treatment of the control group, there was only a small difference between the groups.

Eight women in the control group were excluded from the deferred treatment, as they appeared to be pregnant when their treatment was to start. It is possible that these traumatized women were planning to get pregnant and therefore were interested in participating in the study. Six of these pregnant women were given the possibility to test the modules, but all decided to discontinue after two to four weeks, as they found the therapy too laborious. The on-going pregnancy may have made the treatment more demanding for the women. As they declined to continue, it was not possible for us to follow them over the course of the actual delivery.

Phobic FOC and childbirth-related PTSD are serious psychiatric disorders, and their management requires specific competence. There is a high risk of continued impairment of the pregnant women's mental health if such problems are not identified and adequately treated. These problems also have a high comorbidity with other psychiatric problems (Rouhe et al. 2011; Andersson, Sundström-Poromaa, Wulff, Åström \& Bixo 2006), and thus are easily overlooked if the possibilities of collaboration with psychiatric care and clinical psychologists are not are established within obstetric care. A recent clinical report of Patel and Hol- 
lins (2015) describes the multidisciplinary joint management of mental health problems in pregnancy, and recommends case training of the maternity staff in identification of severe childbirth phobia and prompt referral for shared psychiatric and maternity care. More studies are needed to show the effect of this kind of interventions, including in a Swedish health care context.

\subsection{Methodological considerations - strengths and limitations}

In this thesis, a variety of different methodological approaches have been applied. This includes an epidemiological approach (Study 1), as well as a health economic calculation (Study 2). There are also two trials of ICBT concerning different aspects of childbirth related anxiety. The feasibility study analysed aspects on of FOC treatment, both with a quantitative method (Study 3), and in a qualitative study (Study 4). In the latter, women's narratives before and after therapy were scrutinized with a qualitative approach. The RCT on trauma-focused ICBT examined aspects of the treatment of childbirth-related PTSD with a quantitative method, but also discussed aspects of the study design in light of our experiences (Study 5).

\subsubsection{Study design: questionnaires}

Assessing anxiety-related symptoms has challenges, as different assessing methods do not always correlate well. Also the number of childbirth-specific questionnaires or specific clinical interviews is restricted.

Of the questionnaires used in our studies, only the W-DEQ (Study 1-4) was developed and validated especially in Swedish pregnant women. The TES (Study 5) was developed having childbirth as the traumatic event, but the questionnaire has only received preliminary validation in a Swedish context. The other questionnaires were validated in mixed community samples in other settings, and not tested especially in the context of childbirth, which might have influenced the results, especially when comparing the results of different questionnaires (Study 5). We used mostly self-reporting questionnaires for the assessment of the men- 
tal health problems. Only in Study 5 was a clinical interview (MINI) included. A majority of studies in the field of childbirth-related anxiety rely on questionnaires with self-reported assessment. This should be taken into account when different results are compared.

\subsubsection{Study samples and other methodological aspects}

Our studies have been conducted as multi-centre studies, recruiting in four (Study 1, Paper I) to five (Study 2, Paper II) geographical areas or without geographical restrictions (Study 3-5, Paper III-V) via the Internet. All studies were restricted to Swedish-speaking women in Sweden, limiting the interpretation of the results to this population.

In Study 1, 98.3\% of the eligible women participated, with a good representativeness from the participating areas. A direct comparison of whether the prevalence of FOC had changed was not possible, as the samples in previous studies were not comparable. Only a limited number of socio-demographic variables were studied, and we did not have medical records to analyse, with the result that only a restricted number of variables could be correlated with FOC. The data collection took place already in 2006 , a fairly different time period compared to today, but nevertheless, the results were in line with more recent numbers from a prevalence study in a Swedish sample (Lucasse et al. 2015).

The modest participation in Study 2, i.e. a $60.6 \%$ return of the questionnaires, cannot have influenced the results of comparisons of mean costs in the different groups, although it might have affected the distribution of women over the groups with severe or low FOC.

The cost of illness calculation of severe FOC is based on medical records from the obstetric care services, which do not cover all possible care during the study period. Neither are all societal costs revealed, as the design of our study only included obstetric care, and e.g. did not cover other factors such as the loss of income during the visits. Moreover, costs for the care of the child were not included in the calculations, which possibly also has flattened the difference. But as the parameters generating societal costs were measured in an identical way in the two groups, this should minimize the bias in comparisons although not all 
costs are included. The study was carried out in five different areas, mostly urban regions in the southern part of Sweden. The results should therefore be interpreted with some caution when generalized to the Swedish population.

The way of calculating costs, by grouping in DRG, hided the presumably psychologically more demanding deliveries in bigger groups. For example, vacuum extractions (without other complications) were categorized in the same DRG group as normal vaginal deliveries without complications.

\subsubsection{Internet interventions}

The aim of Studies 3 and 4 was to test the feasibility of a new therapeutic method in the context of obstetrics. However, because the samples were small and we lacked a comparison group, the results should be interpreted with caution. We also wanted to improve our understanding of how the treatment influenced nulliparous women with severe FOC, and therefore, notwithstanding the small samples, there is now a better basis for working further with the method. Fortunately, in Study 5, the RCT, we compared two different conditions, which is considered to be the most reliable approach for such studies, enabling the possibility to include the results in systematic reviews on RCTs.

As there are few studies on treatment of severe FOC and almost no studies on the treatment of postpartum PTSD, the trials offer good information not only about Internet interventions, but also about cognitive behaviour therapy in general in these contexts.

The challenge to inform about a new method when not having direct contact with staff in the recruiting antenatal clinics might have been the reason for the extended enrolment in Studies 3 and 4. Although we spread information about the project widely via various public media to potential participants, and to staff at all Swedish clinics, there was certain scepticism about the program, and some participants received discouraging advice from their midwives at the beginning of the study. Most nulliparous women in Sweden have a good relationship with their midwife on the antenatal care unit. They trust their "own" midwife and 
expect to have the help they need from the antenatal unit. Moreover, pregnant women are probably not prepared to spend extra time on working with mental problems, and as the worrying thoughts can be avoided at the beginning of the pregnancy, many prefer not to think about the approaching delivery until the body reminds them of the inevitable fact.

Self-recruitment might have especially attracted women who were motivated to find information on their problems, and to work on them; many of the participants said that they had heard of the program from an acquaintance, seen an advertisement, or read an article. The bias of selfrecruitment might explain the high level of education among the participants, who probably were used to reading written texts and working via the Internet.

We used self-assessment questionnaires and no structured clinical interview but only a short telephone interview, to assess and measure FOC, depression and anxiety in Study 3, which may have weakened the assessment of these problems.

In the qualitative Study 4, the narratives were sent via the Internet, which may have minimized the interviewer bias, as the informants did not meet an interviewer. The written narratives, based on semistructured questions asked via the Internet, gave a fairly good idea of the informants' expectations. In comparison, to meet an interviewer face-to-face might have offered more extensive information.

In Study 4, the treatment comprised fixed module-based programs increasing the internal validity. This means that all participants were confronted with the same elements of therapy. The advantage of modulebased therapies is that all essential elements are presented; however the possibilities for customizing the therapy to the client's individual needs are limited. Utilization of such standardized programs makes the assessment of the individual's personal problem-profile extra important, which was illustrated by the two participants in whom comorbidity and previous negative life events may have influenced their postpartum results. In clinical practice it is a challenge to balance patients' individual needs and the available treatment possibilities, when the resources are limited. 
CBT requires hard work from the patient, and ICBT is no exception from this, the therapy itself is as demanding over the Internet as face-toface. Because comorbidity with psychiatric disorders is frequent in the group of pregnant women with severe FOC and in women with childbirth related PTSD, ICBT should be provided by professionals with competence in and experience of taking care of a wide spectrum of psychological/psychiatric problems.

Generally speaking, self-report questionnaires are widely used in psychological studies, and are found reliable, especially when they are well validated. In Study 5 we used self-assessment questionnaires to assess and measure symptoms of PTSD, depression, anxiety, and quality of life. Self-reporting may have implied accuracy difficulties in diagnosing the mental problems, which may explain the different numbers of participants meeting all criteria of PTSD, according to the involved questionnaires. In Study 5 we also used the structural clinical MINI interview to assess comorbidity (diagnoses according to DSM-IV) and thus augmented the accuracy of the assessment.

In the trial protocol (Study 5) both modules and treatment time were fixed. This gave the participants eight weeks to complete the program. Many women with severe PTSD symptoms had difficulty keeping up with the pace. A possibility to individualize the pace of the schedule might have been beneficial for at least some women and might have helped more women to complete the entire program. Participants who did not manage to complete one module per week, and thus did not finish the program in time, had access to the remaining modules three months after the study period, and thus had the possibility to continue their therapy work on their own.

At inclusion, a surprisingly large number of participants were depressive. Modules, specifically addressing depression, might also have helped for some women to carry through the entire program.

For the therapists in Studies 3 and 5 the Internet became a virtual therapy room. The possibility of easy accessibility and non-dependence of geographical location enabled continuity to carry on for the therapist also. The written feedback from the therapist dealt mostly with validation, and encouragement to continue working on the therapy tasks. The 
text communications were often short (especially compared with traditional sessions), which enabled a therapist to attend to several participants at a time. The written texts often gave a detailed insight and understanding of the participants' way of thinking about their problems, which probably facilitated the working alliance between the woman and the therapist. One of the challenges in Internet therapy for PTSD is participants' high level of anxiety, because the central coping strategy of PTSD is avoidance. In order to prevent discontinuation, it is important to prepare the potential participant with adequate information and to encourage participation with reminder telephone calls or SMS. In Study 3, we had the possibility to send SMS messages when a participant did not log in during the week, whereas in our trauma-focused ICBT for childbirth-related PTSD symptoms, we did not offer such support. In future trials the possibility to issue reminders may facilitate adherence to the therapy. 


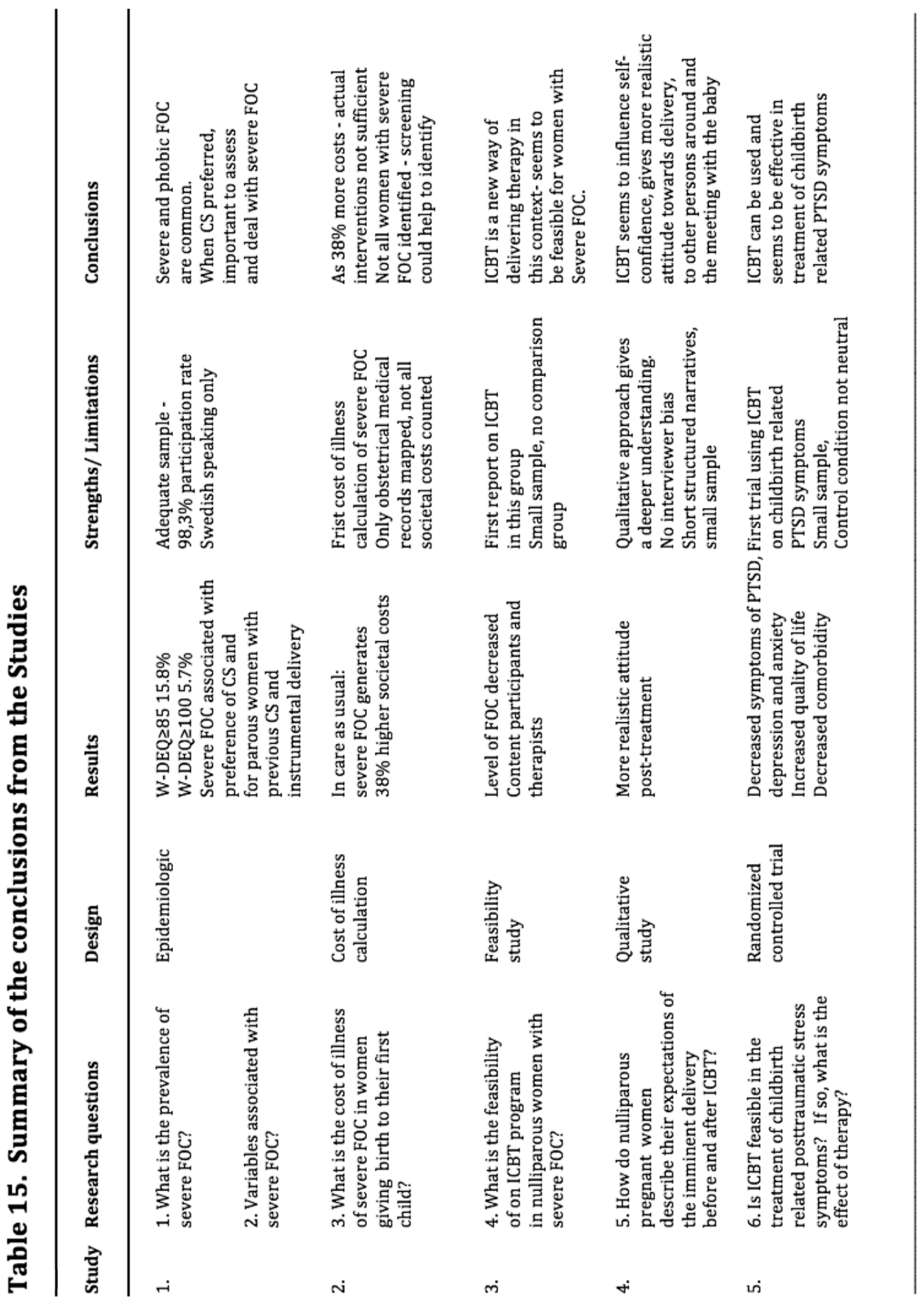




\section{CONCLUSIONS}

Considering the prevalence of severe FOC and variables related to severe FOC and the preference of CS:

- Severe FOC is common in Sweden; at least one out of ten pregnant women is affected by FOC in a clinically significant manner.

- Preference for CS and severe FOC correlate strongly. When a pregnant woman wishes CS as the mode of delivery, it is important to assess possible severe FOC and offer adequate support.

Considering the cost of illness of severe FOC

- The additional societal costs of severe FOC in women giving birth to their first child and managed in ordinary obstetric care are substantial when compared to women with low FOC.

- Severe FOC can be seen as a marker of psychological vulnerability in the perinatal period and is associated with obstetric consequences. Even though not all morbidity can be eradicated by treating severe FOC, it is realistic to expect that there should be significant individual and societal benefits of adequate treatment of severe FOC.

\section{Considering Internet interventions for childbirth anxiety}

- Internet-based CBT is feasible and well accepted by pregnant women as a way of providing treatment even in the obstetric context. The preliminary promising results indicate that ICBT can be one option in future for treating severe FOC.

- CBT seems to affect the attitude of pregnant women with severe FOC towards the imminent delivery, transforming an overwhelming chaotic anxiety into more realistic expectations regarding themselves, their partner, their future child and the staff caring for them.

- Internet-based trauma-focused CBT can be used for the treatment of childbirth-related posttraumatic stress symptoms. The preliminary results are promising, indicating decreasing symptoms of posttraumatic stress. There seem to be positive effects even on symptoms of depression and anxiety as well as on quality of life. 


\section{CLINICAL IMPLICATIONS}

The studies included in this thesis indicate that ICBT can be used in the treatment of severe FOC and of posttraumatic stress symptoms following childbirth.

In some parts of Sweden, ICBT is already established as part of the mental health care system, which could also include women with childbirth anxiety. Since geographical distance is no barrier to treatment via the Internet, such care could be offered even to women in rural areas, who otherwise have problems receiving proper treatment.

ICBT requires hard work and can be as demanding as face-to-face therapy. We know that the women with severe FOC or with childbirthrelated PTSD have a high comorbidity with psychiatric problems. Therefore, ICBT should be provided by properly educated people, who are able to interact professionally with such patients, including correct assessment and treatment.

Lasting effects of therapeutic changes (a re-orientation) require integration of the newly developed effects in the person's thoughts, emotions and behaviour. Therefore, it is important that women who suffer from childbirth anxiety are identified and offered therapy early in pregnancy when facing a feared, imminent delivery, or soon in the postpartum period when possible phobic or traumatic experiences are new, and therapeutically more easily accessible. For women with childbirth-related anxiety, help is urgently needed because many women have a wish for more children. Adequate treatment before such women get pregnant again could be a great relief for these mentally burdened women.

Concerning mental problems related to obstetrics, our research identifies two groups that are seldom identified in ordinary obstetric care, i.e. pregnant women with severe FOC and parous women who have experienced their delivery as traumatic. These groups would profit substantially from proper treatment, and hopefully ICBT will be one of the accessible alternatives in the future. 


\section{CONSIDERATIONS FOR FUTURE RESEARCH}

We have developed and tested new treatment alternatives for severe FOC and childbirth-related PTSD symptoms. The tested Internet-based therapies are feasible for the studied groups and they are easy to administer both for patients and staff. Therefore, the tested programs should be further developed and tested within larger clinical samples, to verify their quality and long-term effects. They should also be compared with traditional, therapist-led treatment. In the future, ICBT treatment modules could possibly be customised for different aspects of mental health problems related to childbirth, and could be developed and studied in order to meet the individual's personal needs. All this in order to achieve the optimal obstetric and psychological care for women (and their families) suffering from FOC and childbirth-related PTSD.

\section{FUNDING}

These studies were supported by grants from the Swedish Research Council for Health, Working Life and Welfare (FORTE), The Medical Research Council of Southeast Sweden (FORSS), The Region Council in Östergötland (RÖ) and Linköping University (LiU). Without these grants the studies would not have been possible. 


\section{ACKNOWLEDGEMENTS}

An undertaking like this would not be possible without the help of others:

First of all, I owe a debt of gratitude to all the women participating in the studies. I feel humble and grateful for the confidence given to me when sharing your private thoughts of these very difficult matters.

Secondly, I would like to express my gratitude to Linköping University and all the staff of the department, especially the administrators, who made my thesis work possible.

My thoughts also go to my supervisors: Professor Klaas Wijma, main supervisor - I am thankful to have been given the opportunity to deepen my knowledge in this fascinating field. Your kind support and generosity with department resources has been a great help over these years in many respects, the immense value of this only became clear afterwards. Professor Gerhard Andersson, co-supervisor; your amazing capacity and knowledge in the field of internet-delivered therapies has opened a whole new world to me; thank you for letting our projects take part of that field of study. Associate Professor Elsa-Lena Ryding, cosupervisor, thank you for introducing me to the world of research and for providing important support during the work on this thesis. Professor Barbro Wijma, co-supervisor, thank you for your independent opinions, and for being the facilitator that made the final phase of this work possible. Thank you also for your hospitality during the visits to your picturesque island retreat. Lecturer, clinical psychologist, Maria Jannert, thank you for all the help with the projects, and for being the warm, empathic person that you are.

I have had invaluable help from specialists in different areas in the different projects: George Vlaescu, thank you for always being there and for providing invaluable support with sometimes uncooperative internet programs. Olof Stephansson, thank you for your skilled help with the statistics during the first study. Anna Malmquist, thank you for opening my eyes to the area of qualitative methodology. Lars Bernfort, thank you for guiding in me in the complex field of health economics. Kristin 
Silfvernagel, thank you for guiding the therapists and myself in the world of internet-based interventions. Ida Berg, Katri Frankenstein, Lina Viita, Kamilla Larsson, Ulrika Persson, Loviisa Spånberger, Anna Wretman; thank you for the exiting voyage in the world of traumafocused interventions. Sanna Johansson and Emelie Kneckt Kinberg, thank you for all your help with the health economics material. Unna Rybom, thank you for being by my side during "the final countdown". Administrators Humlan Svenson, Birgitta Olsson, Therese Björn Johansson and our research midwife Anna Cleveson - without you, our projects would not have been possible. To all the therapists and coworkers in the Victoria research project, I address my thankful thoughts for all the inspiration and support you always offer, glad to have you all in the research team.

I owe some especially warm thoughts to my research colleagues Anke, Johanna, Sabina, Jelmer, Katarina, Birgitta, Siw, Ingegerd, Rikard, Maria, Goldina, Lena, and Anneli - thank you for the diversity of discussions around the coffee-table and in the seminars over the years.

I am also grateful for my clinical employee Region Östergötland and my managers over the years for enabling me to carry on with this research, although the staffing situation has not always been ideal. From this perspective, the cooperation of my clinical colleagues has been invaluable - thank you for your patience. I would like to address a special thank you to the schedulers who have achieved the impossible summary with the working schedules. I have also received help from midwives in Motala and Norrköping, especially in the Ultrasound unit and the Aurora team, thank you for your distributing the questionnaires in the first study and later in the Victoria project.

When working intensively with something interesting, it is easy to forget that there is a real life to be lived. For their persistence in reminding me of what is important in life, I am deeply grateful to all my friends the community of competitive swimming (den stora simmarfamiljen), the housewife society (husmoder-semester sällskapet) and all the families and friends of colleagues that I met during my time in Motala none will be named but none forgotten. Our wonderful neighbours Ulla and Niilo Nikku, and Pelle Brodd with his late wife, Yvonne; Les famil- 
les Vincent, Tamminen and Saalfeldt and Ulla Heine, my "sister of life" with her family - without you, life would not be this richly endowed.

It's on occasions like these that the support of your family becomes invaluable; that is why my thoughts go to my late mother, Birgitta Häkkinen, who always supported me and always remained confident that this work would one day be completed. I owe the original curiosity of the academic world to my father, associate professor Veikko Häkkinen; it has been a pleasure to discuss a diversity of subjects with him during my years of research. Rakel Liehu, my new mother, thank you for opening a window to the world of literature, your warm support has given me more patience and understanding. Leena and Tuomo Penttilä, my inlaws, thank you for supporting our little family over the years. Markus and Kristiina Nymark, my brother and sister-in-law, with their family, thank you for contributing to the quality of my life.

And then - my dear sons Niklas, Anton and Rasmus, you are the most wonderful part of my life - thank you for being the masters of juggling important areas of life. I am going to miss our enjoyable meetings over lunches and dinners in Linköping. Rasmus, a special thank you for helping with the questionnaires and for your company all the evenings when working with the revisions by the fireplace. This recalled some fond memories from my own childhood, when I accompanied my father, sitting by his Remington typewriter. Eva, Anton's sweetheart - I am pleased to have you in our otherwise male dominated family. FannyStina, our dog - thank you for being the mistress of mindfulness - I still have a long way to go...

Finally, Arthur my love and my companion in life, there are no words to express the depth of my gratitude for all the support and help you have given me during this journey - I am looking forward to sharing the future adventures with you! 


\section{SUMMARY IN SWEDISH}

\section{- SAMMANFATTNING PÅ SVENSKA}

Denna avhandling

- undersöker (i) hur vanligt det är att svenska gravida kvinnor lider av rädsla för förlossningen, och (ii) hur detta påverkar kvinnornas sjukvårdskonsumtion under denna period samt vilka kostnader detta innebär för samhället;

- testar och utvärderar (iii) nya behandlingsmetoder för rädsla för förlossningen och för posttraumatiska stressymptom efter en traumatisk förlossning.

\section{Avhandlingen består av fem delstudier:}

Studie 1 var en studie bland 1635 gravida kvinnor och visade att mer än var tionde gravid kvinna har svår förlossningsrädsla. Denna hade samband med kvinnornas önskemål om planerat snitt som förlossningssätt, och hos omföderskor, med tidigare negativa upplevelser av förlossningen.

Studie 2 jämförde sjukvårdskonsumtion och sjukskrivning under graviditet och den första tiden efter förlossningen hos förstföderskor med svår respektive lindrig förlossningsrädsla, vilka omhändertagits i den ordinarie förlossningsvården. Gruppen med svår förlossnings-rädsla visade sig ha avsevärt högre kostnader orsakade av att de i genomsnitt hade högre sjukskrivningstal under graviditet och fler besök på grund av psykiska besvär, samt oftare förlöstes med kejsarsnitt och hade komplicerade förlossningar.

I Studie 3 testade 28 förstföderskor med svår förlossningsrädsla en ny behandlingsmetod med kognitiv beteendeterapi (KBT) via internet. Behandlingen medförde att kvinnornas rädsla kraftigt minskade från före till efter behandling.

I Studie 4 skickade 15 av kvinnorna i Studie 3 in berättelser via nätet om hur de föreställde sig att deras förlossning skulle bli, såväl innan terapin startade som när den var avslutad. Efter genomförd terapi hade kvinnorna en mer realistisk attityd till förlossningen än före terapin och visade tecken på att ha ett bättre självförtroende och mer aktiva strategier att hantera den kommande förlossningen. 
Studie 5 utforskade om kvinnor, som upplevt en traumatisk förlossning, kan bli hjälpta av behandling med KBT via internet. Traumatiserade kvinnor slumpades till att antingen få behandling direkt eller få behandlingen efter en väntetid (kontrollgruppen). I båda grupperna minskade kvinnornas posttraumatiska stressymtom, liksom förekomsten av depression och andra ångestproblem.

Sammanfattning: Avhandlingen visar att svår förlossningsrädsla är vanligt förekommande och medför lidande för kvinnor och ökade kostnader för samhället i samband med graviditet och förlossning, när detta problem hanteras $\mathrm{i}$ den vanliga vården. Två internetbaserade studier testar kognitiv beteendeterapi som behandling för svår förlossningsrädsla och för problem efter en traumatisk förlossning och visar att dessa behandlingsformer tycks fungera väl och i framtiden skulle kunna utgöra ett alternativ som medför att vård görs tillgänglig också för kvinnor som inte har tillgång till kvalificerade hjälpinsatser på andra sätt. Svår förlossningsrädsla och ångestproblem efter en traumatisk förlossning föreligger ofta tillsammans med annan psykisk sjuklighet varför diagnostik och behandling behöver utföras av personer med tillräcklig kompetens för dessa uppgifter. Otillräckligt behandlad/icke behandlad svår förlossningsrädsla ökar riskerna för att kvinnan upplever en kommande förlossning som traumatisk.

Avhandlingens slutsatser behöver undersökas i fler och större studier, och, avseende behandlingsstudierna, i undersökningar som har tillräckligt stora kontrollgrupper. Om sådana studier bekräftar dessa preliminära fynd, blir frågan om screening för svår förlossningsrädsla aktuell eftersom det då finns såväl bra screeninginstrument som behandling som skulle kunna göras tillgänglig för stora grupper. Kommer samhället i denna situation att ha råd att inte försöka förebygga individuellt lidande och stora merkostnader för kvinnor med svår förlossningsrädsla? 


\section{SUMMARY IN FINNISH}

\section{- SUOMENKIELINEN YHTEENVETO}

Tämän tutkimuksen tavoitteena on

- tutkia (i) kuinka yleinen synnytyspelko on ruotsalaisten raskaana olevien naisten keskuudessa ja (ii) kuinka se vaikuttaa heidän terveyden- ja sairaanhoitopalveluiden kulutukseen raskauden aikana ja sen jälkeen, sekä selvittää miten synnytyspelko vaikuttaa yhteiskunnan kustannuksiin;

- kehittää, testata ja arvioida (iii) uusia hoitomuotoja synnytyspelon sekä synnytyksestä johtuvien psykologisen trauman (posttraumaattinen stressi, PTSD) hoitoon.

\section{Tämä väitöskirja koostuu viidestä osatyöstä:}

1. Ensimmäinen osatyö tutki synnystyspelon yleisyyttä 1635 raskaana olevan naisen keskuudessa. Tutkimus osoitti että joka seitsemäs raskaana oleva nainen Ruotsissa kärsii vakavasta synnytyspelosta. Keisarinleikkaus toiveen takana on usein vakava synnystyspelko. Uudelleen synnyttäjillä synnytyspelkoon vaikuttaa myös aiempi traumaattinen synnytyskokemus.

2. Toisessa osatyössa verrattiin ensisynnyttäjien terveyden- ja sairaanhoitokustannuksia sekä sairaslomapäiviä raskauden aikana, synnyksen yhteydessä sekä sitä seuraavan kolmen ensimmäisen kuukauden aikana. Vertailuryhmät seurasivat tavallista äitiysneuvolaohjelmaa, ryhmistä toisella oli vakava ja toisella lievä synnytyspelko. Vakavasta synnytyspelosta kärsivien naisten terveyden- ja sairaanhoitopalvelujen käyttö osoittautui huomattavasti korkeammaksi kuin vertailuryhmässä.

3. Kolmannessa osatyössa 28 vakavasta synnytyspelosta kärsivää ensisynnyttäjää, testasi uutta ratkaisukeskeiseen terapiaan (KBT) pohjautuvaa Internetin kautta ohjattua psykologista hoito-ohjelmaa. Hoito lievensi huomattavasti osallistujien synnytyspelkoa.

4. Neljännessä osatyössä 15 naista (edellisestä osatyöstä 3) kirjoittivat osana terapiaansa kertomuksen tulevan synnytyksensä odotuksista. Sama tehtävä kertautui ennen terapian alkua sekä sen jälkeen. Kertomusten yhtäläiset teemat tunnistettiin minkä jälkeen ennen ja jälkeen hoitoohjelmaa kirjoitettujen kertomusten teemoja vertailtiin. Hoidon jälkeen naisten odotukset pohjautuivat suuremmassa määrin tietoon, he 
kuvailivat itsensä varmemmiksi sekä paremmin valmistautuneiksi tulevaa synnytystä ajatellen.

5. Viides osatyö tutki Internetin kautta ohjatun ratkaisukeskeisen terapian (KBT) vaikutusta naisiin jotka kärsivät synnytyksen jälkeisesta henkisestä traumasta. Naiset satunnaistettiin tutkimuksessa joko välittömän hoidon ryhmään tai odotuslista ryhmään, joka sai saman hoidon myöhemmin. Hoidon jälkeen PTSD oireet vähenivät sekä hoito- että kontrolliryhmässä. Myös masentuneisuus ja ahdistusoireet vähenivät hoidon myötä.

Yhteenvetona voidaan oheisista tutkimuksista todeta että synnytyspelko on yleinen ruotsalaisten raskaana olevien naisten keskuudessa. Synnytyspelko aiheuttaa kärsimystä sekä raskaana olevalle naiselle mutta myös lisäkustannuksia yhteiskunnalle. Kahdessa Internetin kautta ohjatussa ratkaisukeskeisessä hoito-ohjelmassa testattiin uusia hoitomuotoja raskaana oleville ensisynnyttäjille sekä synnytyksen jälkeisistä traumaoireista kärsiville naisille. Tulokset osoittavat, että Internetin kautta ohjattu hoito toimii näissä ryhmissä hyvin ja saattaisi tulevaisuudessa olla vaihtoehto kohderyhmille, joille sopivaa terapeuttista hoitoa nykytilanteessa ei voida tarjota. Koska vaikea synnytyspelko ja synnytystä seuraavat PTSD oireet esiintyvät usein muiden mielialahäiriöiden rinnalla, on tärkeää, että näitä naisia hoitavalla henkilökunnalla on tarpeellinen pätevyys hoitaa myös mielenterveysongelmia. Hoitamatta jätetty tai puutteelisesti hoidettu synnytyspelko lisää raskaana olevan naisen riskiä kokea synnytyksensä traumaattisena.

Tulevissa tutkimuksissa tämän tutkimusprojektin tulokset ja johtopäätökset on syytä toistaa useammissa ja ennen kaikkea suuremmissa ryhmissä. Jos tutkimustemme alustaville tuloksille löytyy tukea, nousee kysymys synnystyspelon seulonnasta äitiysneuvoloissa ajankohtaiseksi; sekä seulontamenetelmä että tehokas hoitotapa ovat olemassa ja voitaisiin tarjota suuremmille kohderyhmille. Onko yhteiskunnalla sellaisessa tilanteessa varaa olla ennaltaehkäisemättä synnystyspelkoisten naisten kärsimystä? 


\section{REFERENCES}

Alehagen, S., Wijma, B., Lundberg, U. \& Wijma, K. (2005). Fear, pain and stress hormones during childbirth. Journal of

Psychosomatic Obstetrics and Gynecology, 26, 153-165.

Alehagen, S., Wijma, B. \& Wijma, K. (2006). Fear of childbirth before, during, and after childbirth. Acta Obstetricia et Gynecologica Scandinavica, 85, 56-62.

American Psychiatric Association, APA. (2000). Diagnostic and Statistical manual of mental disorders, DSM Fourth Edition - Text Revision. Washington DC: American Psychiatric Association. American Psychiatric Association, APA. (2002). MINI-D IV. Diagnostiska kriterier enligt DSM-IV-TR (Quick reference to the Diagnostic Criteria From DSM-IV-TR). Malmö: Pilgrim Press.

American Psychiatric Association, APA. (2013). Diagnostic and statistical manual of mental disorders (DSM-5®). Washington DC: American Psychiatric Pub.

Andersson, G. (2009). Using the Internet to provide cognitive behaviour therapy. Behaviour Research and Therapy, 47, 175-180.

Andersson, G. (2010). The promise and pitfalls of the internet for cognitive behavioural therapy. BioMed Central Medicine, 8, 15.

Andersson, G., Cuijpers, P., Carlbring, P., Riper, H. \& Hedman, E. (2014a). Guided Internet-based vs. face-to-face cognitive behavior therapy for psychiatric and somatic disorders: a systematic review and meta-analysis. World Psychiatry, 13, 288-295.

Andersson, G. \& Titov, N. (2014b). Advantages and limitations of Internet-based interventions for common mental disorders. World Psychiatry, 13, 4-11.

Andersson, L., Sundström-Poromaa, I., Bixo, M., Wulff, M., Bondestam, K. \& Åström, M. (2003). Point prevalence of psychiatric disorders during the second trimester of pregnancy: a population-based study. American Journal of Obstetrics \& Gynecology, 189, 148-154.

Andersson, L., Sundström-Poromaa, I., Wulff, M., Åström, M. \& Bixo, M. (2006). Depression and anxiety during pregnancy and six months postpartum: a follow-up study. Acta Obstetricia et 
Gynecologica Scandinavica, 85, 937-944.

Antony, M. M. \& Swinson, R. P. (2000). Phobic disorders and panic in adults: A guide to assessment and treatment. Washington DC: American Psychological Association.

Areskog, B., Uddenberg, N. \& Kjessler, B. (1981). Fear of childbirth in late pregnancy. Gynecologic and Obstetric Investigation, 12, 262-266.

Areskog, B., Uddenberg, N. \& Kjessler, B. (1984). Postnatal emotional balance in women with and without antenatal fear of childbirth. Journal of Psychosomatic Research, 28, 213-220.

Ayers, S. (2004). Delivery as a traumatic event: prevalence, risk factors and treatment for postnatal posttraumatic stress disorder. Clinical Obstetrics and Gynecology, 47 (3), 552-567.

Ayers, S., Eagle, A. \& Waring, H. (2006). The effects of childbirthrelated post-traumatic stress disorder on women and their relationships: a qualitative study. Psychology, Health \& Medicine, 11, 389-398.

Ayers, S., McKenzie-McHarg, K. \& Eagle, A. (2007). Cognitive behaviour therapy for postnatal post-traumatic stress disorder: case studies. Journal of Psychosomatic Obstetrics and Gynecology, 28, 177-184.

Ayers, S., Joseph, S., Mc-Kenzie-McHarg, K., Slade, P. \& Wijma, K. (2008). Post-traumatic stress disorder following childbirth: current issues and recommendations for future research. Journal of Psychosomatic Obstetrics and Gynecology, 29, 240250.

Ayers, S., Harris, R., Sawyer, A., Parfitt, Y. \& Ford, E. (2009). Posttraumatic stress disorder after childbirth: analysis of symptom presentation and sampling. Journal of Affective Disorders, 119, 200-204.

Ayers, S., Bond, R., Bertullies, S. \& Wijma, K. (2016). The aetiology of post-traumatic stress following childbirth: a meta-analysis and theoretical framework. Psychological Medicine, 46, 11211134.

Bandura, A. (1977). Self-efficacy: toward a unifying theory of behavioral change. Psychological Review, 84, 191-215.

Barlow, D. H. (2004). Anxiety and its disorders: The nature and treatment of anxiety and panic. New York: Guilford press.

Bastos, M. H., Furuta, M., Small, R., McKenzie-McHarg, K. \& Bick, D. 
(2015). Debriefing interventions for the prevention of psychological trauma in women following childbirth. Cochrane Database Systematic Review, 4, 1-63.

Bauer, A., Knapp, M. \& Parsonage, M. (2016). Lifetime costs of perinatal anxiety and depression. Journal of Affective Disorders, 192, 83-90.

Beck, A. T., Epstein, N., Brown, G. \& Steer, R. A. (1988). An inventory for measuring clinical anxiety: psychometric properties. Journal of Consulting and Clinical Psychology, 56, 893-897.

Beck, A. T., Steer, R. A. \& Brown, G. K. (1996). Beck depression inventory - second edition manual. San Antonio, TX:

The Psychological Corporation.

Beck, A. T., Brown, G. K. \& Steer, R. A. (1997). Psychometric characteristics of the Scale for Suicide Ideation with psychiatric outpatients. Behaviour Research and Therapy, 35, 1039-1046.

Beebe, K. R., Lee, K. A., Carrieri-Kohlman, V. \& Humphreys, J. (2007). The effects of childbirth self-efficacy and anxiety during pregnancy on prehospitalization labor. Journal of Obstetric, Gynecologic \& Neonatal Nursing, 36, 410-418. Bellanger, M. M., Quentin, W. \& Tan, S. S. (2013). Childbirth and Diagnosis Related Groups (DRGs): patient classification and hospital reimbursement in 11 European countries. European Journal of Obstetrics \& Gynecology and Reproductive Biology, 168, 12-19.

Bergström, J., Andersson, G., Ljótssib, B., Rück, C., Andréewich, S., Karlsson, A., Carlbring, P., Andersson, E. \& Lindefors, N. (2010). Internet-versus group-administered cognitive behaviour therapy for panic disorder in a psychiatric setting: a randomised trial. BioMed Central Psychiatry, 10, 1-10.

Bijen, G. (2012). Community planning: integrating the social and physical environments. Urban Policy and Research, 30, 471472.

Bjelland, I., Dahl, A. A., Haug, T. T. \& Neckelmann, D. (2002). The validity of the Hospital Anxiety and Depression Scale: an updated literature review. Journal of Psychosomatic Research, 52, 69-77.

Bradley, R., Schwartz, A. C. \& Kaslow, N. J. (2005). Posttraumatic stress disorder symptoms among low-income, African 
American women with a history of intimate partner violence and suicidal behaviors: Self-esteem, social support, and religious coping. Journal of Traumatic Stress, 18, 685-696.

Braun, V. \& Clarke, V. (2006). Using thematic analysis in psychology. Qualitative Research in Psychology, 3, 77-101.

Cannon, D. S., Tiffany, S. T., Coon, H., Scholan, M. B., McMahon, W. M. \& Leppert, M. F. (2007). The PHQ-9 as a brief assessment of lifetime major depression. Psychological Assessment, 19, 247-251.

Carlsson, M., Ziegert, K. \& Nissen, E. (2015). The relationship between childbirth self-efficacy and aspects of well-being, birth interventions and birth outcomes. Midwifery, 31, 1000-1007.

Craske, M. G., Rowe, M., Lewin, M. \& Noriega-Dimitri, R. (1997). Interoceptive exposure versus breathing retraining within cognitive behavioural therapy for panic disorder with agoraphobia. British Journal of Clinical Psychology, 36, 85-99.

Cuijpers, P., Van Straten, A. \& Andersson, G. (2008a). Internetadministered cognitive behavior therapy for health problems: a systematic review. Journal of Behavioral Medicine, 31, 169177.

Cuijpers, P., Van Straten, A., Andersson, G. \& Van Oppen, P. (2008b). Psychotherapy for depression in adults: a meta-analysis of comparative outcome studies. Journal of Consulting and Clinical Psychology, 76, 909-922.

Czarnocka, J. \& Slade, P. (2000). Prevalence and predictors of posttraumatic stress symptoms following childbirth. British Journal of Clinical Psychology, 39, 35-51.

Drummond, M.F., Sculpher, M.J., Torrance, G.W., O'Brien, B.J \& Stoddart, G.1. (2005). Methods for the economic evaluation of health care programmes. Oxford: Oxford university press.

Eriksson, C., Westman, G. \& Hamberg, K. (2005). Experiential factors associated with childbirth-related fear in Swedish women and men: A population based study. Journal of Psychosomatic Obstetrics and Gynecology, 26, 63-72.

Euroqol group. (1990). EuroQol-a new facility for the measurement of health-related quality of life. Health Policy, 16, 199-208.

Fenech, G. \& Thomson, G. (2014). 'Tormented by ghosts from their past': A meta-synthesis to explore the psychosocial 
implications of a traumatic birth on maternal well-being. Midwifery, 30, 185-193.

Fetter, R. B. \& Freeman, J. L. (1986). Diagnosis related groups: product line management within hospitals. Academic Management Review, 11, 41-54.

Fisher, C., Hauch, Y. \& Fenwick, J. (2006). How social context impacts on women's fears of childbirth: A Western Australian example. Social Science \& Medicine, 63, 64-75.

Foa, E. B., Frances, A. \& Davidson, J. R. (1999). Expert consensus guideline series: treatment of posttraumatic stress disorder. Journal of Clinical Psychiatry, 60 (suppl 16), 1-76.

Ford, E. \& Ayers, S. (2011). Support during birth interacts with prior trauma and birth intervention to predict postnatal posttraumatic stress symptoms. Psychology \& Health, 26, 15531570.

Frisch, M. B., Cornell, J., Villanueve, M. \& Retzlaff, P. J. (1992).

Clinical validation of the Quality of Life Inventory. A measure of life satisfaction for use in treatment planning and outcome assessment. Psychological assessment, 4, 92-101.

Furlanetto, L. M., Mendlowich, M. V. \& Bueno, J. R. (2005). The validity of the Beck Depression Inventory-Short Form as a screening and diagnostic instrument for moderate and severe depression in medical inpatients. Journal of Affective Disorders, 86, 87-91.

Gottvall, K. \& Waldenström, U. (2002). Does a traumatic birth experience have an impact on future reproduction? BJOG: An International Journal of Obstetrics and Gynaecology, 109, 254-260.

Grekin, R. \& O'Hara, M. W. (2014). Prevalence and risk factors of postpartum posttraumatic stress disorder: A meta-analysis. Clinical Psychology Review, 34, 389-401.

Gun, S. Y., Titov, N. \& Andrews, G. (2011). Acceptability of Internet treatment of anxiety and depression. Australian Psychiatry, 19, 259-264.

Hall, W. A., Hauck, Y. L., Carty, E. M., Hutton, E. K., Fenwick, J. \& Stoll, K. (2009). Childbirth fear, anxiety, fatigue, and sleep deprivation in pregnant women. Journal of Obstetric, Gynecologic, \& Neonatal Nursing, 38, 567-576.

Hedman, E., Ljóttson, B. \& Lindefors, N. (2012). Cognitive behaviour 
therapy via the Internet: a systematic review of applications, clinical efficacy and cost-effectiveness. Expert Review of Pharmacoeconomics \& Outcomes Research, 12, 745-764.

Hedman, E., Carlbring, P., Ljótsson, B. \& Andersson, G. (2014). Internetbaserad psykologisk behandling: evidens, indikation och praktiskt genomförande.(Internet-based psychological treatment: The evidence, indications and practical implementation) Stockholm: Natur \& Kultur.

Heimstad, R., Dahloe, R., Laache, I., Skogvoll, E. \& Schei, B. (2006). Fear of childbirth and history of abuse: implications for pregnancy and delivery. Acta Obstetricia et Gynecologica Scandinavica, 85, 435-440.

Ivarsson, D., Blom, M., Hesser, H., Carlbring, P., Enderby, P., Nordberg, R. \& Andersson, G. (2014). Guided internetdelivered cognitive behavior therapy for post-traumatic stress disorder: a randomized controlled trial. Internet Interventions, 1, 33-40.

Johansson, R. \& Andersson, G. (2014). Internet-based psychological treatments for depression. Expert Review of Neurotherapeutics, 12, 861-870.

Johnson, R. \& Slade, P. (2003). Obstetric complications and anxiety during pregnancy: is there a relationship? Journal of Psychosomatic Obstetrics and Gynecology, 24, 1-14.

Kessler, R. C., Sonnega, A., Bromet, E., Hughes, M. \& Nelson, C. B. (1995). Posttraumatic stress disorder in the National Comorbidity Survey. Archives of General Psychiatry, 52, 1048-1060.

Kessler, R. C. (2000). Posttraumatic stress disorder: the burden to the individual and to society. Journal of Clinical Psychiatry, 61, 1, 478-512.

Kessler, D., Lewis, G., Kaur, S., Wiles, N., King, M., Weich, S., Sharp, D. J., Araya, R., Hollinghurst, S. \& Peters, T. J. (2009).

Therapist-delivered Internet psychotherapy for depression in primary care: a randomised controlled trial. The Lancet, 374, 628-634.

Kjaergaard, H., Wijma, K., Dykes, A. K. \& Alehagen, S. (2008). Fear of childbirth in obstetrically low-risk nulliparous women in Sweden and Denmark. Journal of Reproductive and Infant Psychology, 26, 340-350. 
Kroenke, K., Spitzler, R. L. \& Williams, J. B. (2001). The PHQ-9. Journal of General Internal Medicine, 16, 606-613.

Lange, A., Rietdijk, D., Hudcovicova, M., Van De Ven, J.-P., Schrieken, B. \& Emmelkamp, P. M. (2003). Interapy: a controlled randomized trial of the standardized treatment of posttraumatic stress through the internet. Journal of Consulting and Clinical Psychology, 71, 901-909.

Larsson, B., Karlström, A., Rubertsson, C. \& Hildingsson, I. (2015).

The effects of counseling on fear of childbirth. Acta

Obstetricia et Gynecologica Scandinavica, 94, 629-636.

Laursen, M., Hedegaard, M. \& Johansen, C. (2008). Fear of childbirth: predictors and temporal changes among nulliparous women in the Danish National Birth Cohort. BJOG: An International Journal of Obstetrics and Gynaecology, 115, 354-360.

Lazarus, R. S. (1991). Cognition and motivation in emotion. American Journal of Psychology, 46, 352-367.

Lukasse, M., Vangen, S., Oian, P., Kumle, M., Ryding, E.L. \& Schei, B. (2010). Childhood abuse and fear of childbirth-a population-based study. Birth, 37, 267-274.

Lukasse, M., Schei, B. \& Ryding, E.L. (2014). Prevalence and associated factors of fear of childbirth in six European countries. Sexual \& Reproductive Healthcare, 5, 99-106.

Lukasse, M., Laanpere, M., Karro, H., Kristjansdottir, H., Schroll, A.M., Van Parys, A.-S., Wangel, A.-M. \& Schei, B. (2015). Pregnancy intendedness and the association with physical, sexual and emotional abuse - a European multi-country crosssectional study. BioMed Central Pregnancy \& Childbirth, 15, $1-9$.

McKenzie-McHarg, K., Ayers, S., Ford, E., Horsch, A., Jomeen, J., Sawyer, A., Stramrood, C., Thomson, G. \& Slade, P. (2015). Post-traumatic stress disorder following childbirth: an update of current issues and recommendations for future research. Journal of Reproductive and Infant Psychology, 33, 1-19.

Melender, H.L. (2002). Experiences of fears associated with pregnancy and childbirth: a study of 329 pregnant women. Birth, 29, 101111.

National Board of Health and Welfare (Socialstyrelsen) (2015). Statistik rapporter: Graviditeter, förlossningar och nyfödda barn 19912013 (Pregnancies, deliveries and newborns - Swedish Medic 
al Birth Register 1991-2013 ) Available from:

www.socialstyrelsen.se/publikationer2015/2015-12-27.

Nicholls, K. \& Ayers, S. (2007). Childbirth-related post-traumatic stress disorder in couples: A qualitative study. British Journal of Health Psychology, 12, 491-509.

Nilsson, C., Lundgren, I., Karlström, A. \& Hildingsson, I. (2012). Selfreported fear of childbirth and its association with women's birth experience and mode of delivery: A longitudinal population-based study. Women and Birth, 25, 114-121.

Nolen-Hoeksema, S., Frederickson, B., Loftus, G. \& Wagenaar, W. (2014). Atkinson and Hilgard's Introduction to Psychology. Hampshire, United Kingdom: Mason, $\mathrm{OH}$ : Cengage.

Nordic Casemix Center. www.nordcase.org/eng/products/groupers/ Olde, E., Van Der Hart, O., Kleber, R. \& Van Son, M. (2006). Posttraumatic stress following childbirth: a review. Clinical Psychology Review, 26, 1-16.

Pang, M. W., Leung, T. N., Lau, T. K., Chung, H. \& Kwok, T. (2008). Impact of first childbirth on changes in women's preference for mode of delivery: follow-up of a longitudinal observational study. Birth, 35, 121-128.

Patel, R. R. \& Hollins, K. (2015). Clinical report: the joint obstetric and psychiatric management of phobic anxiety disorders in pregnancy. Journal of Psychosomatic Obstetrics and Gynecology, 36, 10-14.

Petit, P. (2015). Prise en charge de la tocophobie par thérapie cognitivocomportementale: à propos d'un cas clinique. (Treatment of Tocophobia with Cognitive Behaviour Therapy: a case study) Journal de Thérapie Comportementale et Cognitive, 25, 3-11. Robjant, K. \& Fazel, M. (2010). The emerging evidence for narrative exposure therapy: a review. Clinical Psychology Review, 30, 1030-1039.

Rosqvist, J. (2012). Exposure treatments for anxiety disorders: a practitioner's guide to concepts, methods, and evidence-based practice. New York: Routledge.

Rouhe, H., Salamela-Aro, K., Halmesmäki, E. \& Saisto, T. (2009). Fear of childbirth according to parity, gestational age, and obstetric history. BJOG: An International Journal of Obstetrics and Gynaecology, 116, 67-73.

Rouhe, H., Salmela-Aro, K., Gissler, M., Halmesmäki, E. \& Saisto, T. 
(2011). Mental health problems common in women with fear of childbirth. BJOG: An International Journal of Obstetrics and Gynaecology, 118, 1104-1111.

Rouhe, H., Salmela-Aro, K., Toivanen, R., Tokola, M., Halmesmäki, E. \& Saisto, T. (2013). Obstetric outcome after intervention for severe fear of childbirth in nulliparous women - randomised trial. BJOG: An International Journal of Obstetrics and Gynaecology, 120, 75-84.

Rouhe, H., Salmela-Aro, K., Toivanen, R., Tokola, M., Halmesmäki, E., Ryding, E.L. \& Saisto, T. (2015a). Group psychoeducation with relaxation for severe fear of childbirth improves maternal adjustment and childbirth experience-a randomised controlled trial. Journal of Psychosomatic Obstetrics and Gynecology, 36, $1-9$.

Rouhe, H., Salmela-Aro, K., Toivanen, R., Tokola, M., Halmesmäki, E. \& Saisto, T. (2015b). Life satisfaction, general well-being and costs of treatment for severe fear of childbirth in nulliparous women by psychoeducative group or conventional care attendance. Acta Obstetricia et Gynecologica Scandinavica, 94, 527-533.

Ryding, E.L. (1993). Investigation of 33 women who demanded a cesarean section for personal reasons. Acta Obstetricia et Gynecologica Scandinavica, 72, 280-285.

Ryding, E.L., Wijma, B., Wijma, K. \& Rydhström, H. (1998). Fear of childbirth during pregnancy may increase the risk of emergency cesarean section. Acta Obstetricia et Gynecologica Scandinavica, 77, 542-547.

Ryding, E.L., Persson, A., Onell, C. \& Kvist, L. (2003). An evaluation of midwives' counselling of pregnant women in fear of childbirth. Acta Obstetricia et Gynecologica Scandinavica, $82,10-17$.

Ryding, E.L., Wirfelt, E., Wängborg, I.-B., Sjögren, B. \& Edman, G. (2007). Personality and fear of childbirth. Acta Obstetricia et Gynecologica Scandinavica, 86, 814-820.

Ryding, E.L., Lukasse, M., Parys, A. S. V., Wangel, A. M., Karro, H., Kristjansdottir, H., Schroll, A. M. \& Schei, B. (2015). Fear of childbirth and risk of cesarean delivery: a cohort study in six European countries. Birth, 42, 48-55.

Räisänen, S., Lehto, S., Nielsen, H., Gissler, M., Kramer, M. \& 
Heinonen, S. (2014). Fear of childbirth in nulliparous and multiparous women: a population-based analysis of all singleton births in Finland in 1997-2010. BJOG: An International Journal of Obstetrics and Gynaecology, 121, 965-970.

Saisto, T., Salmela-Aro, K., Nurmi, J. E. \& Halmesmäki, E. (2001).

Psychosocial characteristics of women and their partners fearing vaginal childbirth. BJOG: An International Journal of Obstetrics and Gynaecology, 108, 492-498.

Saisto, T. \& Halmesmäki, E. (2003). Fear of childbirth: a neglected dilemma. Acta Obstetricia et Gynecologica Scandinavica, 82, 201-208.

Salmela-Aro, K., Read, S., Rouhe, H., Halmesmäki, E., Toivanen, R. M., Tokola, M. I. \& Saisto, T. (2012). Promoting positive motherhood among nulliparous pregnant women with an intense fear of childbirth: RCT intervention. Journal of Health Psychology, 17, 520-534.

Salomonsson, B., Gullberg, M. T., Alehagen, S. \& Wijma, K. (2013). Self-efficacy beliefs and fear of childbirth in nulliparous women. Journal of Psychosomatic Obstetrics and Gynecology, 34, 116-121.

Sandström, M., Wiberg, B., Wikman, M., Willman, A.-K. \& Högberg, U. (2008). A pilot study of eye movement desensitisation and reprocessing treatment (EMDR) for post-traumatic stress after childbirth. Midwifery, 24, 62-73.

Shapiro, F. \& Maxfield, L. (2002). Eye movement desensitization and reprocessing (EMDR): information processing in the treatment of trauma. Journal of Clinical Psychology, 58, 933-946.

Sheehan, D. V., Lecrubier, Y., Sheehan, K. H., Amorim, P., Janavs, J., Weiller, E., Hergueta, T., Baker, R. \& Dunbar, G. C. (1998). The Mini-International Neuropsychiatric Interview (M.I.N.I): the development and validation of a structured diagnostic psychiatric interview for DSM-IV and ICD-10. Journal of Clinical Psychiatry, 59, 22-33.

Sjögren, B. \& Thomassen, P. (1997). Obstetric outcome in 100 women with severe anxiety over childbirth. Acta Obstetricia et Gynecologica Scandinavica, 76, 948-952.

Sjögren, B. (1998). Fear of childbirth and psychosomatic support. A follow up of 72 women. Acta Obstetricia et Gynecologica 
Scandinavica, 77, 819-825.

Sluijs, A.-M., Cleiren, M. P., Scherjon, S. A. \& Wijma, K. (2012). No relationship between fear of childbirth and pregnancy/delivery-outcome in a low-risk Dutch pregnancy cohort delivering at home or in hospital. Journal of Psychosomatic Obstetrics and Gynecology, 33, 99-105.

Spence, J., Titov, N., Dear, B. F., Johnston, L., Solley, K., Lorian, C., Wootton, B., Zou, J. \& Schwenke, G. (2011). Randomized controlled trial of Internet-delivered cognitive behavioural therapy for posttraumatic stress disorder. Depression and Anxiety, 28, 541-550.

Spice, K., Jones, S. L., Hadjistavropoulos, H. D., Kowalyk, K. \& Stewart, S. H. (2009). Prenatal fear of childbirth and anxiety sensitivity. Journal of Psychosomatic Obstetrics and Gynecology, 30, 168-174.

Spielberger, C. D., Gorsuch, R. L., Lushene R., Vagg P. R., Jacobs, G. A. (1983). Manual for the State-Trait Anxiety Inventory: STAI (Form Y). Palo Alto, CA: Consulting Psychologists Press. Spånghagen, P. (2010). Psykometriska egenskaper för Traumatic Event Scale vid PTSD postpartum (Psychometric aspects of traumatic event scale used at PTSD postpartum). (Master thesis.

Department of Psychology). Uppsala: Uppsala University. Statistics Sweden (Statistiska centralbyrån SCB) (2013). Statistical database. Wages, Salaries and Labour costs. Available from: www.scb.se/en_/Finding-statistics/Statistics-by-subjectarea/Labour-market/Wages-salaries-and-labour-costs/Salarystructures-whole-economy/Aktuell-Pong/14374/149077/

Sterne, J. A., White, I. R., Carlin, J. B., Spratt, M., Royston, P., Kenward, M. G., Wood, A. M. \& Carpenter, J. R. (2009). Multiple imputation for missing data in epidemiological and clinical research: potential and pitfalls. BMJ-British Medical Journal, 338, 157-160.

Storksen, H. T., Eberhard-Gran, M., Garthus-Niegel, S. \& Eskild, A. (2012). Fear of childbirth; the relation to anxiety and depression. Acta Obstetricia et Gynecologica Scandinavica, 91, 237-242.

Stramrood, C. A., Van Der Velde, J., Doornbos, B., Paarlberg, M., Weijmar Schultz, W. \& Van Pampus, M. G. (2012). The patient observer: Eye-Movement Desensitization and 
Reprocessing for the treatment of posttraumatic stress following childbirth. Birth, 39, 70-76.

Sydsjö, G., Sydsjö, A., Gunnervik, C., Bladh, M. \& Josefsson, A. (2012). Obstetric outcome for women who received individualized treatment for fear of childbirth during pregnancy. Acta Obstetricia et Gynecologica Scandinavica, 91, 44-49.

Sydsjö, G., Angerbjörn, L., Palmquist, S., Bladh, M., Sydsjö, A. \& Josefsson, A. (2013). Secondary fear of childbirth prolongs the time to subsequent delivery. Acta Obstetricia et Gynecologica Scandinavica, 92, 210-214.

Sydsjö, G., Bladh, M., Lilliecreutz, C., Persson, A.M., Vyön, H. \& Josefsson A. (2014) Obstetric outcomes for nulliparous women who received routine individulized treatment for severe fear of childbirth - a retrospective case control study. BioMed Central Pregnancy Childbirth, 14, 1-7.

Sydsjö, G., Moller, L., Lilliecreutz, C., Bladh, M., Andolf, E. \& Josefsson, A. (2015). Psychiatric illness in women requesting caesarean section. BJOG: An International Journal of Obstetrics and Gynaecology, 122, 351-358.

Söderquist, J., Wijma, K. \& Wijma, B. (2002). Traumatic stress after childbirth: the role of obstetric variables. Journal of Psychosomatic Obstetrics and Gynecology, 23, 31-39.

Söderquist, J., Wijma, K. \& Wijma, B. (2004). Traumatic stress in late pregnancy. Journal of Anxiety Disorders, 18, 127-142.

Söderquist, J., Wijma, B. \& Wijma, K. (2006). The longitudinal course of post-traumatic stress after childbirth. Journal of Psychosomatic Obstetrics and Gynecology, 27, 113-119.

Söderquist, J., Wijma, B., Thorbert, G. \& Wijma, K. (2009). Risk factors in pregnancy for post-traumatic stress and depression after childbirth. BJOG: An International Journal of Obstetrics and Gynaecology 116, 672-680.

Tarricone, R. (2006). Cost-of-illness analysis: what room in health economics? Health Policy, 77, 51-63.

Toohill, J., Fenwick, J., Gamble, J. \& Creedy, D. K. (2014a). Prevalence of childbirth fear in an Australian sample of pregnant women. BioMed Central Pregnancy Childbirth, 14, $1-10$.

Toohill, J., Fenwick, J., Gamble, J., Creedy, D. K., Buist, A., Turkstra, E. \& Ryding, E.L. (2014b). A randomized controlled trial of 
a psycho-education intervention by midwives in reducing childbirth fear in pregnant women. Birth, 41, 384-394.

Torgersen, S. (1985). Hereditary differentiation of anxiety and affective neuroses. British Journal of Psychiatry, 146, 530-534.

Waldenström, U., Hildingsson, I. \& Ryding, E.L. (2006). Antenatal fear of childbirth and its association with subsequent caesarean section and experience of childbirth. BJOG: An International Journal of Obstetrics and Gynaecology, 113, 638-646.

Weiss, D.S. (2007). The impact of event scale: revised. In Wilson, J \& So-Kum Tang, C. (eds.) Cross-cultural assessment of psychological trauma and PTSD. New York: Springer US,

Vickers, A. J. \& Aaltman, D. G. (2001). Analysing controlled trials with baseline and follow up measurements. BMJ: British Medical Journal 323, 1123-1124.

Wijma, K., Söderquist, J. \& Wijma, B. (1997). Posttraumatic stress disorder after childbirth: a cross sectional study. Journal of Anxiety Disorders, 11, 587-597.

Wijma, K., Ryding, E.L. \& Wijma, B. (1998a). Predisposing psychological factors for posttraumatic stress reactions after emergency cesarean section. Acta Obstetricia et Gynecologica Scandinavica, 5, 231-237.

Wijma, K., Wijma, B. \& Zar, M. (1998b). Psychometric aspects of the W-DEQ; a new questionnaire for the measurement of fear of childbirth. Journal of Psychosomatic Obstetrics and Gynecology, 19, 84-97.

Wijma, K., Alehagen, S. \& Wijma, B. (2002). Development of the delivery fear scale. Journal of Psychosomatic Obstetrics and Gynecology, 23, 97-107.

Wijma, K. (2003). Why focus on 'fear of childbirth'? Journal of Psychosomatic Obstetrics and Gynecology, 24, 141-143.

Wijma, K. (2006). Post-traumatic stress disorder and childbirth. In O'Keane, V., Marsh, M. \& Senevirate, G. (eds.) Psychiatric disorders and pregnancy. London: Taylor and Francis.

Wijma, K., Saita, E., Fenaroli, V. (2010). Posttraumatic stress disorder (PTSD) following childbirth. In Cigoli V. \& Gennari M. (eds.) Close relationships and community psychology: an international perspective. Milano: Franco Angeli.

Wijma, K. \& Wijma, B. (2016). A woman afraid to deliver - how to manage childbirth anxiety. In Paarlberg, K. M. \& Van de 
Wiel, H. B. M. (eds.) Biopsychosocial Obstetrics and Gynaecology. Berlin: Springer.

Wiklund, I., Edman, G. \& Andolf, E. (2007). Cesarean section on maternal request: reasons for the request, self-estimated health, expectations, experience of birth and signs of depression among first-time mothers. Acta Obstetricia et Gynecologica Scandinavica, 86, 451-456.

Zar, M. (2001). Diagnostic aspects of fear of childbirth (PhD Thesis. Linköping Studies in Education and Psychology No.78). Linköping: Linköping University.

Zar, M., Wijma, K. \& Wijma, B. (2001). Pre-and postpartum fear of childbirth in nulliparous and parous women. Scandinavian Journal of Behaviour Therapy, 30, 75-84.

Zar, M., Wijma, K. \& Wijma, B. (2002). Relations between anxiety disorders and fear of childbirth during late pregnancy. Clinical Psychology \& Psychotherapy, 9, 122-130.

Zigmond, A. S. \& Snaith, R. P. (1983). The hospital anxiety and depression scale. Acta Psychiatrica Scandinavica, 67, 361-370. 
Papers I-V

PAPERS I-V 



\section{Papers}

The articles associated with this thesis have been removed for copyright reasons. For more details about these see:

http://urn.kb.se/resolve?urn=urn:nbn:se:liu:diva-126494 